\title{
ELESTADO SOCIAL DE DERECHO Y LA SOSTENIBILIDAD FISCAL EN COLOMBIA
}

SANDRA MILENA AYALA REYES

UNIVERSIDAD SANTO TOMAS

FACULTAD DE DERECHO

MAESTRIA EN DERECHO PÚBLICO

COHORTE SEXTA

BOGOTÁ D.C. 
EL ESTADO SOCIAL DE DERECHO Y LA SOSTENIBILIDAD FISCAL EN

COLOMBIA

SANDRA MILENA AYALA REYES

Trabajo de grado para optar al título como

Magister en Derecho Público

Asesor

UNIVERSIDAD SANTO TOMAS

FACULTAD DE DERECHO

MAESTRIA EN DERECHO PÚBLICO

COHORTE SEXTA

BOGOTÁ D.C.

2016 
Dedico este trabajo de manera muy especial a: 
Agradecimientos

A... 
Nota de aceptación

Firma del presidente del Jurado

Firma del Jurado

Firma del Jurado

Bogotá D.C., de 2016 


\section{Contenido}

Pág.

RESUMEN

Palabras Clave

Diseño Metodológico

Problema Jurídico

Pregunta de Investigación

Planteamiento del Problema

Objetivo General

Objetivos Específicos

INTRODUCCIÓN

CAPÍTULO 1

El Estado Social y Democrático de Derecho y Jurisprudencia sobre el Incidente del Impacto Fiscal

1.1 Referencia Doctrinal

1.2 Referencia Jurisprudencial

1.3 Principio del Estado Social de Derecho/Principio Democrático

1.4 La Sostenibilidad Fiscal y el Incidente de Impacto Fiscal

CAPITULO 2

La globalización Neoliberal como amenaza al Estado Social y Democrático de Derecho 2.1 ¿Colombia un país neoconservador o un país neoliberal? 
2.2 Equilibrio constitucional entre lo económico y lo social y la labor judicial frente al Incidente de Impacto Fiscal

\subsection{Hermenéutica Jurídica Constitucional}

CAPÍTULO 3

Relación entre constitucionalismo y globalización en el Estado social y democratico de derecho

CAPÍTULO 4

Antecedentes de la Sostenibilidad Fiscal, la estabilidad macroeconómica y la progresividad de los derechos- Un análisis jurisprudencial

\section{CAPÍTULO 5}

La sostenibilidad fiscal en la Constitución Política de Colombia y sus repercusiones en los fallos de responsabilidad patrimonial del Estado

CAPÍTULO 6

Las políticas económicas y el Incidente del Impacto Fiscal en el Estado social de Derecho

CAPÍTULO 7

¿El Estado Fiscal en Colombia?

Conclusiones.

Referenciasy Citas Bibliograficas 


\section{RESUMEN}

La tesis expone los fundamentos filosóficos, jurídicos, económicos y políticos desde la doctrina nacional e internacional y la jurisprudencia colombiana, del concepto del Estado social de derecho como expresión democrática del país y las incidencias de su desarrollo por factores de la macroeconomía globalizada y por la reciente figura jurídica de la Sostenibilidad Fiscal del país y su instrumento el Incidente de Impacto Fiscal declarado constitucional por la Corte Constitucional.

Las anteriores hipótesis se expresan, de acuerdo con los postulados de una república unitaria, descentralizada, con autonomía de sus entidades territoriales, democrática y pluralista y fundada en el respeto de la dignidad humana y en la prevalencia del interés general para cumplir los fines esenciales del Estado, establecidos principalmente en $\operatorname{los}$ artículos $1^{\mathrm{o}}$ y $2^{\mathrm{o}}$ de la Constitución Política vigente, que constituyen la democracia constitucional en Colombiay que de conformidad con las premisas anteriores, estos enunciados no se cumplen plenamente por factores de la política pública de la rama ejecutiva y por decisiones de la rama judicial cuando procede el Incidente de Impacto Fiscal, que afectaría la protección de los derechos de los ciudadanos y que en su conjunto representan expresiones formales de justicia social a cargo de los gobiernos y de justicia distributiva como función judicial.

De esta forma se plantean las posibles incidencias que pueden afectar la expresión de dos ramas del poder público en cumplimiento de postulados constitucionales y legales, por factores macroeconómicos y por la reciente figura jurídica de la Sostenibilidad y el Incidente de Impacto 
Fiscal, que en suma, podrían constituir una posible amenaza para la vigencia material del Estado social de derecho.

Además de este análisis, la tesisenuncia y analiza de manera especial las amenazas que inciden en el normal funcionamiento del Estado como expresión social y democrático por la injerencia de políticas de orden fiscal, que comienza a erigirse con peso en la estructura pública de la administración colombiana y que hace pensar para unos,que se pueden presentar amenazasa la materialización del Estado social de derecho y que responde a un enfoque estructuralista; frente a otra concepción de carácter funcional,que justifica un fortalecimiento de una justicia constitucional responsable, cuando se fijan las condiciones económicas de la hacienda pública que hacen "funcional" y racional la distribución de los bienes y servicios a cargo de los gobiernos como expresión de la justicia social y de razón pública, que es compartida mediante una hermenéutica argumentadapor parte de la rama judicial en la interpretación del derecho y en ejercicio de la justicia distributiva.

Por consiguiente, la tesis igualmente contempla de manera importante,la influencia de la doctrina económica fundada en el neoliberalismo inicialmente citada y las nuevas vocaciones macroeconómicas que cobran mayor importancia en el impacto de expresión del Estado social con preeminencia sobre la figura jurídica de la Sostenibilidad y el Incidente de Impacto Fiscal,que fuera recientemente creado en el ordenamiento constitucional, mediante el acto legislativo 03 de 2011 y desarrollada por la Ley 1695 de 2013. 
De esta manera la tesis, enfatizay caracteriza a lo largo de su desarrollo conceptual, el instrumento de la política fiscal en Colombia y llega a la conclusión que no logra incidir negativamente para unos,en la garantía de los derechos fundamentales y los derechos económicos, sociales y culturales; y para otros, expresa que si contribuiría de manera positiva racional y con responsabilidad fiscal, en la formulación de políticas a través de la administración pública y la administración judicial para lo cual se apoya en las decisiones de la Corte Constitucional en jurisprudencia reiterada.

En este sentido, se hace mención de manera especial a las sentencias C-288 y C-332 de 2012 de la Corte Constitucional, que declararon su exequibilidad ydejan en firme la reforma a los artículos 334, 339 y 346 de la Carta Política.

\section{Palabras Clave}

Estado, Estado de Derecho, Estado Social de Derecho, Sostenibilidad e Incidente de Impacto Fiscal, Derecho Constitucional, Economía, Neoliberalismo, Globalización, Democracia, Estructuralismo y Funcionalismo. 


\section{Diseño Metodológico}

La presente tesis es de corte analítico y de naturaleza cualitativa. En consecuencia, corresponde a un desarrollo conceptual mediante hipótesis empíricas y específicas de orden jurídico y económico, para llegar a conclusiones sobre el tema de indagación.

Relaciona la génesis de la implementación teórica y práctica del Estado Social de derecho con la precisa descripción y desglose de sus elementos característicos frente a las implicaciones de la figura de la Sostenibilidad Fiscal y el Incidente de Impacto Fiscal en su aplicación y sus vínculos con la economía y el derecho, en un contexto jurídico nacional y se analiza en orden de importancia con el fenómeno de la globalización económica imperante en el país mediante dos enfoques del conocimiento científico: El Estructuralismo y el Funcionalismo.

Como necesario resultado, la tesis es el resultado de una investigación documental, jurídica, económica y argumentativa, desde un enfoque analítico sobre los principales conceptos de la doctrina nacional e internacional, la jurisprudencia de la Corte Constitucional, y la consulta de la normatividad y de los principales doctrinantes nacionales y extranjeros,en relación con el Estado social de derecho y su relación con la macroeconomía globalizada y la Sostenibilidad yel Incidente de Impacto Fiscal a propósito de sus más recientes fallos de constitucionalidad que tutela la rama judicial respecto de la constitucionalidad del Acto Legislativo y el desarrollo legal sobre la materia. 
La investigación utilizada en la tesis, acude a hechos demostrables conceptualmente que parten de la realidad doctrinaria y jurisprudencial de orden constitucional, social, política y económica colombiana e internacional y la confronta con las realidades de la sociedad capitalista regida por una Constitución Política, que a su vez quiso plasmar la garantía de unas reivindicaciones sociales a través de derechos, en procura de una justicia social a cargo de los gobiernos y otra distributiva a cargo de los jueces.

Igualmente se adentra en las consideraciones del modelo económico y político colombiano que se las realidades macroeconómicas y de instrumentos jurídicos, como la figura jurídica de la Sostenibilidad Fiscal y el Impacto de Sostenibilidad Fiscal para la racionalidad del gasto público que podría relativizarlos derechos económicos, sociales y colectivos que consagra el Estado social de Derecho.

La delimitación metodológica, se funda en la indagación de fuentes del conocimiento basada en una amplia concepción teórica y jurídica en las materias que son determinadas como desarrollo conceptual y teórico, para lograr finalmente unas conclusiones fundadas en la materia del derecho público en cada uno de sus apartes; y en el acápite final, se acude a conclusiones generales que plantea las dos visiones a los cuales se ha hecho referencia desde el punto de vista estructural y funcional, como económico y jurídico, de conformidad con un manifiesto de justicia constitucional responsable, a la cual aspiran todos los colombianos.

En consecuencia y de acuerdo con su desarrollo, el tipo de la investigación responde igualmente a un enfoque histórico, teórico descriptivo, analítico u holístico. 
Este enfoque de la investigación cualitativa y conceptual, pone de manifiesto la importancia de la subjetividad de la teoría del contrato social que lleva implícito la figura del Estado Social de derecho frente a la Macroeconomía globalizada y la Sostenibilidad y el Incidente de Impacto Fiscal, la asume de manera crítica-constructiva y la hace su eje fundamental de desarrollo.

De otra parte, permite construir el conocimiento de la realidad colombiana y de las estructuras jurídicas y sociales como punto de partida y plantea su futuro como prospectiva del sistema social de bienestar a partir de un enunciado constitucional paradigmático.

\section{Problema Jurídico}

El Estado social y democrático de derecho en Colombia, no corresponde a un enfoque estructuralista de garantía de justicia y razón, por el contrario, es un enunciado formal en derechos y libertades, que corresponde a los elementos y naturaleza política y jurídica del Estado de derecho meramente formal, que no se materializa por amenazas latentes que plantea la economía global ya descrita, donde las razones macroeconómicas en el sistema político y económico del país, acuden a limitaciones fiscales para el correcto manejo de la macroeconomía, pero que puede incidir en el recorte de derechos a los ciudadanos y donde el Incidente de Impacto Fiscal podría contribuir de manera restrictiva en la esencia constitucional garantista de derechos. 
Esta digresión como antecedente histórico, que más adelante se dimensiona, no se ha podido superar en el enunciado y cumplimiento real del Estado social de vida republicana, al restringir la materialidad del Estado concebido comodemocrático, participativo y pluralista fundado en el interés general, concepción que demanda el análisis del impacto de la figura constitucional de la Sostenibilidad y el Incidente de Impacto Fiscal que alteraría para algunos (estructuralistas) el pacto social de 1991 a través del acto legislativo 03 de 2011 y de la Ley 1695 de 2013; y que para otros (funcionalistas), consideran que simplemente se ajustó una realidad de la administración pública de coordinación armónica y que cuenta con la interpretación apropiada de los jueces en su autonomía, todo lo cual en suma, representa el análisis fundamental en la presente tesis de grado en derecho público.

Para absolver el problema jurídico planteado, la investigación pretende igualmente resolver la siguiente

\section{Pregunta de Investigación}

¿La sostenibilidad fiscal elevada a rango constitucional puede constituir una amenaza para la consolidación y materialización del Estado Social de Derecho en Colombia y consecuencialmente una alteración al pacto político de 1991, desde el punto de vista estructural de la concepción del Estado?

Esta esuna inicial pregunta de orden metodológico que surge de acuerdo con el enunciado constitucional inicialmente citado que consagró el Estado Social, y que a su vez, posibilitó un modelo económico funcional fundado en la empresa privada nacional e internacional, dando paso a una nueva realidad en la época de pos modernidad: El Estado de derecho, de corte Globalizado que ha consolidado una democracia capitalista paralela al Estado Social, al cual se sumaría la figura constitucional de la "Sostenibilidad y el Incidente de Impacto Fiscal” consagrado a través del acto legislativo 03 de 2011 y desarrollado por la Ley 
1695 de 2013, donde se podrían relativizar los derechos fundamentales y los derechos sociales, económico, y culturales frente a la defensa de los postulados económicos del neoliberalismo, como la propiedad privada, la libertad económica, la racionalización de la economía, la limitación a la intervención del Estado, la consolidación de la estabilidad macroeconómica, entre los más importantes como análisis necesario.

\section{Planteamiento del Problema yObjetivo General}

La tesis pretende formular una hipótesis a través de las amenazas que enfrenta el Estado Social y democrático de Derecho en Colombia, respecto a su capacidad real o material de garantizar los derechos fundamentales, derechos humanos, derechos colectivos y los valores tradicionales como la libertad, la igualdad, la seguridad, en procura de las condiciones necesarias para el desarrollo humanoen el Estado, donde el modelo económico y la figura jurídica de la "Sostenibilidad y el Incidente de Impacto Fiscal" incorporada a nuestro ordenamiento constitucional a través del acto legislativo 03 de 2011 y desarrollado por la Ley 1695 de 2012 , podrían constituir determinar negativamente la materialización del Estado social y democrático a plenitud, según un enfoque estructuralista; en contrario de una progresividad que relativiza los derechos por la defensa de un modelo económico igualmente constitucional consagrado en el título XII, en sus artículos 332 a 373 y de sus reformas y desarrollos legales que son necesarios para optimizar la Administración Pública como inicialmente se advirtió y que parte de un análisis funcionalista o formal del derecho y sus efectos. 


\section{Objetivos Específicos}

- Enunciar la concepción y naturaleza del Estado Social de Derecho, sus antecedentes históricos y retos para el siglo XXI.

- Identificar los retos que debe asumir el Estado Social y Democrático de Derecho respecto del modelo económico colombiano y la figura jurídica de la Sostenibilidad y el Incidente de Impacto Fiscal como instrumento de la administración pública en coordinación con la rama judicial. 


\section{INTRODUCCIÓN}

Por lo expuesto en el resumen que antecede y de manera especial como delimitación metodológica de la tesis, se aborda en este inicial acápite un análisis jurisprudencial y doctrinal sobre el origen y conceptualización del Estado social y democrático de derecho y su incidencia frente a la figura de la Sostenibilidad y el Incidente de Impacto Fiscal, la estabilidad macroeconómica y la progresividad de los derechos, partiendo del análisis político social, macroeconómico, constitucional, jurisprudencial, legal y doctrinal en la materia, con especial énfasis en la descripción de las políticas del neoliberalismo, de la globalización y de sus últimas políticas de la minería extractiva de las riquezas naturales, previa la evolución del concepto de democracia y los vínculos entre el poder y el derecho donde podría aparecer en igual jerarquía postulados de un Estado fiscal.

Para desarrollar estas hipótesis, la tesis acude a las conclusiones más importantes respecto de este análisis comparativo entre dos concepciones, una eminentemente social y estructural, y otra con delimitaciones fiscales con enfoque formal y funcional, que pretenden respectivamente materializar la democracia colombiana con responsabilidad fiscal por razones macroeconómicas y como expresión de un Estado de derecho al servicio inserto en un modelo económico neoliberal y de modelo minero extractivo. 
Estos conceptos se analizan desde la realidad constitucional, social, política y económica colombiana con observancia de los antecedentes históricos y filosóficos, advirtiendo que actualmente no se garantizan plenamente los derechos que garantiza el Estado social y democrático de derecho, donde se afectade manera estructural la capacidad del gobierno nacional para garantizar los valores tradicionales como la justicia, la libertad, la igualdad y la seguridad, como consecuencia de un contexto de orden económico,donde confluyen diversas problemáticascomo el conflicto armado, el conflicto social y económico, la corrupción administrativa y de manera especial; las razones macroeconómicas que responden a una formulación neoliberal, igualmente previstoen el título XII constitucional que permite y garantiza la empresa privada como motor del desarrollo para fortalecer las finanzas públicas que se retribuyen en asignación de bienes y servicios y de respeto de derechos a los ciudadanos.

Como ya se indicó, se une a los factores económicos antes enunciados, otra hipótesis que podría amenazar la materialización del Estado social, configurando de esta forma, una multi causalidad de factores, comoes la figura jurídica de la Sostenibilidad y el Incidente de Impacto Fiscal, considerada por unos como amenaza y por otros, como una mera herramienta de la política fiscal de carácter formal, que coadyuva a la distribución de bienes y servicios a los ciudadanos bajo la premisa de una justicia constitucional responsable y razonable y dentro de un modelo político de social democracia con instrumentos económicos como los ya enunciados, como la mayoría de democracias de América Latina.

A la luz de estas inferencias, se establecen los retos que afrontarán a futuro los gobiernos para garantizar el apropiado desarrollo del Estado social y democrático de derecho en Colombia, 
enmarcado hoy en un escenario de grandes inequidades, influenciadas en buena medida por el mundo globalizado, que ha traído al escenario de democracia en el país,un modelo económico que se presenta como inequitativo, donde la interpretación de la figura jurídica conocida como la Sostenibilidad y el Incidente de Impacto Fiscalque fuera elevada a rango constitucional,podría incidir e impactar la concepción y garantía del modelo económico y político del Estado Social y democrático de Derechode manera negativa, desde un enfoque estructuralista, de indudable importancia sobre las decisiones judiciales que amparan derechos consagrados en la Constitución Política de 1991.

De otra parte, se expone otra corriente que defiende esta figura constitucional, al considerar que ésta no ofrecería mayores dificultades, de conformidad con la corriente doctrinaria que consulta la formulación formal del Estado de derecho o meramente funcionalista.

Frente a estas diversas concepciones planteadas sobre las diferentes escuelas de conocimiento científico social en la materia, el autor toma partido para sustentar su tesis para procurar mayor claridad alos enfoques teóricos descritos y llegar a unas conclusiones generales una vez se desarrollan conceptualmente los temas propuestos de indagación.

Previas las consideraciones que anteceden, se puede dar inicio a la temática prevista con la siguiente cita:

"Por esto que, en esta tendencia "democrática del neoliberalismo", han emergido diversas teorizaciones sobre la cuestión democrática desde una perspectiva postliberal como la de Rawls, 
socialista como la de Habermas y pos socialista, tal como se presentan en las propuestas de la democracia radical posthabermasiana de la tercera generación de la escuela de Frankfurt, de la democracia real de Negri y Hart en el marco del capitalismo global, de la democracia disputadora del republicanismo postmoderno, y de la democracia de liberación de Touraine, definiendo con ello un marco normativo que posibilite dar cuenta de los procesos contestatarios en curso, así como infiriendo de allí, no solo eventuales tendencias objetivas que permitan prefigurar estrategias frente al capitalismo global neoliberal, sino también y ante todo, una concepción de resistencia o desobediencia civil-incluso insumisión- como defensa activa de la Constitución, a ser tenida en cuenta por los tribunales constitucionales en sus procesos de adjudicación" ( Jiménez Marín, pág. 118).

Luego de esta advertencia ideológica y teórica, y de un análisis teórico sobre los elementos y naturaleza del Estado social, la figura de la Sostenibilidad y el Incidente de Impacto Fiscal, las relaciones entre el derecho y el poder, la labor de los jueces en este importante tema y la importancia de un Estado Fiscal en Colombia, se exponen las conclusiones y las perspectivas jurídicas que se desprenden del desarrollo temático realizado inicial a través de unas hipótesis que obliga a unas respuestas.

Para efectos de ubicar en contexto el título de la tesis y su desarrollo, se da inicio a las consideraciones sobre el marco teórico del Estado Social de Derecho como concepto y desarrollo teórico el cual posee una historia importante a partir de mediados del siglo XIXen Europa y con relación a otros conceptos y principios de derecho imperantes en la época como el enunciado formalista del Estado de Derecho que imperó en Colombia hasta 1991. 
Para un inicial enfoque de esta evolución de los conceptos citados, se acudirá a las concepciones de dos tratadistas europeos que constituyen los orígenes teóricos sobre los enfoques de este modelo político constitucional y que Colombia adoptara en 1991 con algunos avances y restricciones que nos lleva necesariamente a su análisis en diversas perspectivas.

Para el desarrollo de este importante aspecto histórico,se acudirá principalmente a lo largo del trabajo a las consideraciones teóricas desarrolladas por el tratadista Gerardo Meil Landwerlin, en su estudio "El Estado Social de Derecho: Forsthoff y Abendroth; cuando presenta dos interpretaciones teóricas para dos posiciones políticas, las cuales nos indican de manera introductoria el debate jurídico del problema planteado en la presente tesis y que será de indudable utilidad para llegar a las conclusiones.

Expresan estos importantes autores y precursores alemanes del Estado social, que el origen de la cláusula del Estado Social de Derecho se remonta a la República de Weimar que consagrara los derechos sociales en el texto constitucional, con desarrollo posterior del tratadista Hermann Heller a mediados de 1930, donde concibe a esta fórmula de concepción sobre el Estado, como antítesis al modelo del Estado liberal y frente a concepciones totalitarias como las consideradas en 1917 a propósito de la revolución bolchevique, e introduce el adjetivo social en la Alemania de 1848 , cuando se asocia las ideas de justicia social y de igualdad y lo que es más importante, para contextualización de la presente tesis, en la ordenación de la economía a los objetivos sociales del hombre, mediante dos enfoques: Uno estructuralista de Abendroth y otro 
funcionalista de parte de Forsthoff a cuyas escuelas de pensamiento se han citado como enfoque de los problemas sociales.

Después estos dos enfoques, se caracterizan al constituir uno las ideas concebidas como de izquierda para el caso de Abendroth, y de derecha o funcional, para el caso de Forsthoff.

Por su parte, H Heller, acude al concepto de Estado de Derecho y lo articula en relación a las ideas de justicia y razón. Esta concepción guía a la burguesía liberal en contra de la monarquía reinante de la época del siglo XIX.

Esta fórmula, se materializa finalizada la Segunda Guerra mundial en Alemania, mediante la ley fundamental de Bonn de 1948.

Pero antes, el tratadista Abendroth ya citado, encuentra sus raíces a mediados del siglo XIX, a propósito de las primeras organizaciones obreras que desencadenaron la revolución parisina de 1848, y que desarrollan en su momento, el autor García Pelayo en su obra "Las transformaciones del Estado contemporáneo" y de otra parte el tratadista Lorenz Von Stein en 1850; donde de igual manera contribuye a esta concepción de Estado, un tratadistade la importancia de Ferdinand Lasalle.

Estos inicios de la concepción obrera de Abendroth, sobre el Estado social no logra expresarse como política de Estado al no lograrse el poder en 1917, paralelo al comienzo de la 
Primera Guerra Mundial, que vino a aplazar este importante pensamiento como modelo político en Europa.

Ernst Forsthoff, por su parte, concibe la idea de lo social con un principio fundamental concebido como logro de la revolución francesa de 1789, donde la fraternidad,aparece consagrada en la Declaración Universal de los Derechos del Hombre, pero que desaparece, al no desarrollar ningún derecho positivo.

Este autor, desarrolla el concepto del Estado social en la obra de Lorenz Von Stein en 1869, como manifestación de expresión de la monarquía social, cuando asignaba responsabilidades a la administración en la atención de las necesidades sociales y fundamentalmente a través de la garantía de la seguridad social como periodo posterior a la Segunda Guerra Mundial.

De igual manera, separa lo que es administración y lo que significa política. Para este autor el Estado de derecho y el Estado social son dos formas diferentes de ver el Estado.

"La disputase sitúa en torno al carácter jurídico de los llamados derechos sociales reconocidos en el texto constitucional, esto es, como organización técnico-jurídica de los llamados derechos sociales reconocidos en el texto constitucional o al carácter de norma jurídica de la Constitución. La Constitución, para Forsthoff es, por encima de todo, un instrumento jurídico de ordenación política, por tanto, de administración del poder legítimo, su ámbito de referencia es el poder. La administración, por el contrario, y en oposición de Forsthoff, tiene su 
ámbito de referencia únicamente en la prestación de servicios, no suponiendo, implícitamente, ningún acto de poder político. Aparece por tanto, una oposición básica, función social versus poder, que enmarca los ámbitos de las esferas de Administración y de la política; "las funciones sociales del Estado son funciones prestadoras. Sirven para posibilitar una existencia digna a los ciudadanos del Estado. Si son transformadas en medios de dominación, pierden entonces el carácter social. Función social y poder se excluyen mutuamente”. (Landwerlin:1984)

Por su parte, W Abendroth, sostiene lo siguiente: “...Asocia al Estado social de derecho el derecho a la determinación democrática de todo el orden estructural de la sociedad y de la economía, donde sufre degradación el derecho a la participación...que siguiera el contenido de la Ley Fundamental y que realizara el Estado social y democrático de derecho, programación que debiera estar construida de tal forma que estuviese orientada hacia la reconstrucción total de la ordenación social y económica, sustituyendo la aparente librecompetencia de la economía oligopolista por una economía planificada en interés de la totalidad social " (Landwerlin: 1984).

Es decir, para este autor no es solamente un problema de libertad individual, sino que corresponde a un problema de participación democrática, y en tal sentido, sostiene que los órganos del Estado han de estar sometidos y orientados a la construcción del Estado social, entendido éste, en términos de planificación democrática centralizada y de control democrático de la reestructuración económica y social.

Tenemos entonces, que el Estado de Derecho, fue la forma que adoptó la organización política como reacción al modelo absolutista. Estaconcepción del Estado, como Estado liberal de 
derecho o Estado Burgués, buscaba garantizar el derecho natural de los individuos y que garantizaba la vida, la libertad, la igualdad formal y la propiedad, pero no se concebía los elementos dados como el derecho a la participación que trata la Constitución Política Colombiana de 1991.

Posteriormente, llegamos al Estado constitucional o de supremacía de una ley, en este caso la Constitución, que se direccionó a la garantía de los derechos y las libertades públicas, en lo que se ha conocido como la República.

De otra parte,

...la teoría del Estado Social de Derecho fue formulada por Hermann Heller a comienzos del siglo XX en su obra Estado de Derecho o Dictadura...este concepto ya había sido expuesto por Lorenz Von Stein en 1848, en el concepto del debate que surgió por la incapacidad para dar respuesta a la problemática social. (Defensoría del Pueblo, 2001, p. 21) y sobre el cual se ha desarrollado sus tesis a través de los autores Abendroth y Forshoff ya citados.

Este Estado social de derecho, como se ha observado tiene una historia relevante en el derecho público y según señala a su vez el doctor Younes, uno de los primeros en desarrollar la idea del Estado Social fue el alemán Lorenz Von Stein, el cual expuso en el siglo XIX que con la finalización de la época de las revoluciones políticas se generarían grandes reformas sociales, proponiendo una distinción entre sociedad y Estado que comienza a materializarse en la 
Constitución de 1948 en Alemania como ya se indicó y posteriormente en Gran Bretaña y desde los años cuarenta, cuando aparece el concepto del Estado de Bienestar o Welfare State y de allí parte el concepto alemán del estado social en 1949 en su constitución cuando se consideró un Estado Federal Democrático y Social.

Esta diferencia radica principalmente en la idea que corresponde al Estado sobre el desarrollo de la personalidad del individuo; mientras que la sociedad influye hacia la miseria y sumisión porlas relaciones de propiedad que genera. Seafirma así que en este tipo de sociedad quien domina las cosas tiene poder para dominar a las personas.

De otra parte, históricamente la formulación de este Estado de derecho tuvo unas características necesarias de enunciar a lo largo del siglo XIX y en esta dirección se ha ocupado espacio importante en este acápite introductorio.

Lo primero que es necesario decir para nuestro caso nacional, es que “...hoy, después de 200 años de historia constitucional, la aspiración de tener una sociedad justa sigue viva. Las relaciones de exclusión, explotación y discriminación se han perpetuado y la Constitución, que busca ser la guía política, social y económica, no ha logrado esta aspiración, que ha de ser mediatizada por la creación de normas justas que permitan la convivencia y superación del conflicto social...a través de la historia los marcos constitucionales y legales han estado al servicio de sectores dominantes, contrarios a las aspiraciones de la sociedad, situación por la cual el conflicto social se ha perpetuado desde 1850 a 1991” (Carvajal, J pág. 172). 
Frente a esta realidad histórica, el Estado social de derecho busca que la justicia y el orden estén acordes con las realidades sociales de un país y que los gobernantes y gobernados no vivan en función de una ley, sino que por el contrario la ley responda a las necesidades de la sociedad, según señalan Gómez y Londoño (p. 34).

Al respecto escribe Vidal(1996):

Traduce la quiebra de los postulados de la filosofía individualista que surgió de las revoluciones liberales del siglo XVIII en América y en Europa; así como la gran preocupación por la igualdad económica y social (negrillas fuera del texto) de las personas, que ha sido fundamental en las confrontaciones políticas del presente siglo (p. 380).

Aunque Lorenz Von Stein fue ya enunciado como uno de los primeros en visualizar esta nueva idea de Estado, se atribuye a Hermann Heller la idea de incluir el carácter social al Estado de Derecho, como respuesta a la crisis del Estado de derecho y la democracia, como ya se destacó.

Iván Vila (2007) describe esta situación comoresultandoa las dificultades que se vivían y que requería darle un contenido social al Estado. Sin embargo no es sino hasta la terminación de la Segunda Guerra Mundial como ya se precisó, que el concepto cobra mayor fuerza, específicamente en los países que resultaron perdedores en el conflicto bélico, tales como Alemania e Italia. 
La figura del Estado social de derecho surge como oposición a otros dos modelos de estado que hasta el momento se podían observar en diferentes países, es decir, el estado liberal y el estado totalitario, motivo por el cual nace la idea de este nuevo concepto de Estado donde se busca garantizar la justicia e igualdad para cada individuo, y para ello se integra a las Constituciones Políticas asociándolo con los principios y valores y que representan las bases jurídicas del ordenamiento jurídico y político de un país.

Con la finalización de la Segunda Guerra Mundial Alemania buscó una reorganización de su sistema político y jurídico, motivo por el cual se redactó una nueva Constitución Política en la ciudad de Bonnpara el año de 1949, en la que se incluye este concepto ya descrito como Estado Federal Democrático y Social.

Aquí no se concibe el abandono del Estado de derecho formado sobre el positivismo jurídico, sino que por el contrario, busca fortalecerse con un contenido económico - social tendiente a una mejor distribución de bienes y servicios, dando mayor importancia al individuo que hasta entonces es concebido solamente como un ser libre e igual. En España, esta nueva fórmula se adoptará en la Constitución de 1978, no obstante tener como antecedente en lo social, la Carta de 1931. (González, 2007, p. 17)

Bajo esta ideal la sociedad es parte activa dentro del actuar del derecho y el desarrollo del Estado, interviniendo en las decisiones como gestora y no solo como una figura subordinada de las políticas que emanen de una clase dominante. Es decir que gobierno y sociedad o gobierno y gobernados ya no son figuras distantes una de la otra, sino que por el contrario son figuras complementarias y partícipes en un mismo proceso de desarrollo del Estado. 
Esta será una de nuestras conclusiones más importantes cuando se acuda a la construcción de un sujeto social en un modelo más participativo que nos lleve a la deliberación en un proceso social, que de manera indudable demandara décadas para alcanzar niveles de justicia social y distributiva de manera razonada, según los enunciados de Abrenderth, John Rawls J Habermas, que en nuestras conclusiones tendremos en consideración para respaldar teóricamente nuestras afirmaciones frente al modelo neoliberal imperante en Colombia.

En ese orden de ideas, la correlación y correspondencia de la comunicación entre gobernantes y gobernados se constituye en uno de los pilares esenciales del Estado Social de Derecho, pues por ningún motivo se puede pensar que el epicentro del movimiento del Estado sea un factor distinto a la sociedad, a cada uno de sus habitantes o gobernados. (Gómez \& Londoño, 2010. p. 25).

Con la adopción del Estado Social de Derecho en la legislatura dedistintos países alrededor del mundo se pudo evidenciar puntos que identifican las diferencias entre el Estado de Derecho o Estado liberal y el Estado social de derecho. Mientras que el Estado de Derecho (ED) garantiza solo la seguridad y administrar justicia, el Estado Social de Derecho (ESD) garantiza condiciones materiales mínimas para cubrir las necesidades básicas de la sociedad; el ED (estado de derecho) posee intervenciones mínimas confiando en las acciones del individuo, en contraposición del ESD que ostenta una intervención más amplia en la vida de las personas buscando satisfacer las necesidades que poseen; en el ED existe una clara división en el papel que asume la sociedad y Estado estableciendo una relación que los separa, mientras que el ESD busca 
un trabajo conjunto; en el ED los poderes funcionan de manera separada, en el ESD, por el contrario, los poderes ejecutivo, legislativo y judicial trabajan en coordinadamente; el ED le da gran importancia al poder legislativo, y en el ESD e le otorga mayor trascendencia al poder judicial por estar vinculado a la labor de defensa constitucional; el ED redacta la Constitución enfocada como norma política, especializándose en la determinación y estructuración del poder, a diferencia del ESD que establece la Constitución como norma jurídica especializada en un fin social; el ED tiene una democracia representativa y el ESD una democracia participativa, para lo cual crea organismos especiales que la garantizan; el ED exige un no hacer del Estado y el ESD promueve todo lo contrario; en el ED la libertad es un concepto formal y en el ESD la dignidad humana es un concepto de libertad mínima material como base para que el individuo pueda ejercer sus derechos; el ED tiene sus fundamentos en la eclecticidad de ideas liberales, conservadoras y socialistas, mientras que el ESD se legitiman en la defensa de los derechos fundamentales.

Así pues el ESD representa un cambio en el Estado tradicional con nuevas condiciones que se empiezan a practicar en las naciones europeas, donde los problemas sociales consiguen una nueva dimensión de derecho adquiriendo una mayor relevancia, principalmente por las condiciones que enfrentó este continente en su periodo de posguerra.

En Colombia el Estado Social de Derecho aparece con la aprobación de la Constitución Política de 1991, teniendo como característica que el cambio en el documento no solo radica en el texto sino en la concepción del Estado donde la igualdad es el fundamento y principal principio orientador. La Carta Magna en su artículo 1 reza: 
Colombia es un Estado social de derecho, organizado en forma de república unitaria, descentralizada, con autonomía de sus entidades territoriales, democrática, participativa y pluralista, fundada en el respeto de la dignidad humana, en el trabajo y la solidaridad de las personas que la integran y en la prevalencia del interés general. (Castro, 2007, p. 14).

Como bien lo ha expuesto la Corte Constitucional en la Sentencia C-566 de 1995:

El Estado social de derecho, se proyecta en la Constitución, en primer término, en la consagración del principio de igualdad como derecho a las diferencias y en su consecuencia obligada: los derechos sociales y económicos y en la prestación de los servicios públicos. En segundo término, a través de los derechos de participación de todos en las decisiones que los afectan y en la vida económica, política, administrativa y cultural de la nación, que se compendian en el principio democrático y gracias al cual se socializa el Estado y las diferentes instancias de poder dentro de la comunidad.

El avance del Estado social de derecho, postulado en la Constitución, no responde al inesperado triunfo de ninguna virtud filantrópica, sino a la actualización histórica de sus exigencias, las cuales no son ajenas al crecimiento de la economía y a la activa participación de los ciudadanos y de sus organizaciones en el proceso democrático. (Colombia, 1995, p 1)

De esta manera la inclusión del Estado social de derecho dentro de la Constitución de 1991 representa un cambio y un pacto social de respeto, tolerancia y participación que da cabida 
a que el constituyente se convierta en el origen del nuevo ordenamiento y el eje para lograr la defensa de los derechos fundamentales, en especial de las minorías excluidas, mediante el apoyo del pluralismo y el respeto a la diferencia, para que exista una verdadera redistribución de la riqueza y con garantía de los mínimos materiales para los individuos.

La actual Constitución establece que se deben garantizar unas condiciones razonables de vida a todos los colombianos, sin importar la forma de gobierno, buscando el bienestar común y la justicia social; en este proceso se dieron nuevos deberes al Estado, lo cual representó que el carácter social se inyectara a todo el sistema jurídico colombiano.

"Una amplia gama de derechos, sociales, económicos y culturales quedaron establecidos en la nueva Constitución...sin embargo aunque la Constitución de 1991 reconoció importantes derechos, también impidió su concreción a partir de las políticas económicas neoliberales acogidas, que van en contravía de los derechos sociales. Tal fenómeno se ha expresado en los siguientes términos: "La definición de Colombia como un Estado social de derecho llega en momentos en que la economía de mercado estaba en la cúspide de las preocupaciones de la dirigencia política dominante”. (Carvajal, J p 181).

De otra parte, el mismo Estado social de derecho, en Colombia, dio tránsito de manera paralela hacia una economía más orientada al mercado y en su Título XII, artículos 332 a 373, consagró la defensa de los postulados del neoliberalismo y los derechos sociales y económicos quedaron supeditados al crecimiento económico que quedaría en ultimas del mercado con ausencia progresiva del intervencionismo y vigilancia estatal. 
Se ha impuesto en consecuencia la lógica del mercado sobre la lógica política y social, donde la función constitucional y legal ha sido instrumento necesario para postular una aparente justicia constitucional responsable que se pregona frente a las decisiones judiciales en la tutela y reivindicación de derechos sociales, económicos y culturales.

De esta forma, la Constitución Política, se inclinó más por el desmonte del Estado Keynesiano de bienestar y dio la bienvenida al Estado shumpeteriano (Grupo de trabajo en los años setentas) que analizan la privatización, la desregulación, la modernización, la descentralización, el régimen de asignación de competencias, el régimen de planeación, presupuesto y banca central, entre otros.

Joseph Shumpeter, fue un austriaco-estadounidense, profesor de la Universidad de Harvard y dentro de sus múltiples investigaciones, se ocupó del fenómeno económico en los Estados y predijo la descomposición del Capitalismo, como consecuencia de su propio éxito, crisis que comienza a partir del año 2007.

John Keynes, por su parte, fue un economista inglés que lideró los principios del liberalismo económico a inicios del siglo XX, sostenía que era necesaria una adecuada relación entre la oferta y la demanda, pues de ella dependían los beneficios empresariales y el desarrollo económico para la inversión Estatal a propósito de la gran depresión de 1930 en el mundo cuando se requería de un proceso que reactivara la economía, donde igualmente era necesario poner en actividad el dinero para estimular de manera moderada los procesos inflacionarios e incrementar los salarios. 
En este aspecto y como desarrollo de estas escuelas económicas “...tenemos entonces que con la Carta del 91 se establece un nuevo rol del Estado como agente que coordina, promociona y regula desde una perspectiva muy privatista la acción del mercado. Es decir es un Estado que se limita a apoyar al mercado bajo seis líneas de acción: 1. Garantizar la estabilidad macroeconómica; 2. Efectuar inversiones públicas en capital humano y físico; 3.Crear un entorno competitivo para el sector privado; 4. Promover el desarrollo institucional; 5. Salvaguardar el medio ambiente; 6. Proteger a los grupos sociales vulnerables". (Jiménez A, p 120).

De esta manera, estas acciones estatales, cuentan con un instrumento jurídico como el impacto de sostenibilidad fiscal, que ha dividido un sector de la opinión política y jurídica, respecto de sus conveniencias o inconveniencias, en procura de la vigencia plena del Estado social de derecho y que es objeto de análisis en este primer capítulo ante las hipótesis de amenaza a su real expresión por parte del modelo económico neoliberal y de la Sostenibilidad Fiscal y su Incidente de Impacto Fiscal, objeto de desarrollo en la presente tesis.

“Como resultado de estas expectativas, en lo económico y en lo social se han ido gestando dos lógicas de justicia: la primera, una justicia que se encarga de justificar los interés económicos privados, cuyos beneficiarios son los grandes capitales nacionales e internacionales; la segunda, una justicia que se preocupa por la cuestión social demandada por trabajadores, campesinos, mujeres y en general los movimientos sociales como justicia anhelada". (Carvajal, J p 182).

Por las razones ya expuestas, la temática de desarrollo de la tesis, tiene que ver con las disciplinas del derecho, la filosofía, la ciencia política, la economía y su política fiscal de manera interdisciplinaria para logar la comprensión integral propuesta. Persiguen estas disciplinas un 
mismo objetivo pero lo expresan de manera diferente y coinciden frente al rol del Estado social de derecho en procura de los intereses generales de los ciudadanos, consagrado en el artículo $1^{\circ}$ constitucional.

Los abogados trabajan en la definición de los derechos y los economistas buscan el desarrollo económico para lograr esos fines, y el Estado se convierte en un árbitro entre los derechos y los recursos disponibles. En este contexto la figura del incidente del impacto de sostenibilidad fiscal como el caso que nos ocupa, es objeto de sus estudios interdisciplinarios para proyectar las acciones del Estado, representadas en sus gobiernos para la asignación o distribución de bienes y servicios, bajo la egida de una sociedad regida principalmente por el mercado con ausencia real de intervencionismo estatal, donde imperan los análisis funcionalistas sobre los enfoques estructuralistas inicialmente vistos y donde las relaciones entre las ramas del poder público y un órgano como la Procuraduría General de la Nación revisten sustancial importancia en su relación, de la cual nos ocuparemos más adelante en detalle.

Por ahora podemos afirmar que el derecho prioriza así los derechos, y la economía, prioriza los recursos escasos disponibles. La globalización neoliberal por su parte, plantea una utopía irrealizable: recursos abundantes frente a los recursos que siempre serán escasos y los gobiernos plantean una realidad consecuencial: limitación de recursos y derechos.

En esta vía la expresión de justicia razonada pregonada por J Rawls se convierte cada vez más difícil, en razón a que el entendimiento de la justicia para estos sectores económicos a los 
cuales se ha hecho referencia, responden al papel del derecho en el desarrollo económico de manera funcional y de utilidad para la administración pública.

"El trinomio derecho, desarrollo y democracia, se convirtió en punto de partida para las reformas desarrolladas en la administración de justicia. Aspectos como la resolución de conflictos, la creación de procedimientos ágiles, la implementación de tecnología en los despachos judiciales y la mayor independencia de la rama judicial fueron propuestos en Colombia para dar eficiencia y seguridad jurídica a la administración de justicia”. (Carvajal, J p 183).

En consecuencia, mientras la justicia distributiva se dedicaba a estos factores al servicio de la administración de justicia, los sectores que detentan el poder económico disfrutaban de los excedentes económicos y financieros que le ofrecía el mercado sin generar empleo.

Al parecer, en Colombia se ha dado el triunfo de los economistas frente al poder ciudadano en los cuales se empeñan en defender los abogados desde la interpretación funcional del derecho y que más adelante profundizamos.

Sobre este tema por considerarlo de especial interés de conformidad con las doctrinas teóricas expuestas, y de acuerdo con las premisas que anteceden, se desarrollan los conceptos economicistas y sociales de la democracia colombiana enmarcada en la escuela funcionalista y capitalista vista. 
Según lo visto, en Colombia existe un divorcio entre las dos concepciones desde el Estado que se expresa a través de los gobiernos, cuando no se consultan los derechos encaminados hacia el interés general y se toman las grandes decisiones en la formulación e implementación de las políticas públicas que hacen nugatorio el Estado social al consultar más los intereses que empoderan el Estado capitalista o funcional; que las políticas encaminadas a la reducción delas injusticias sociales desde un análisis estructuralista. Esta es la discusión que nunca acaba.

En Colombia ha tomado prioridad esta concepción del Estado capitalista que consulta las reglas que sustentan los mercados distorsionados, en los cuales las corporaciones y empresas multinacionales en asocio del mercado nacional explotan económicamentemediante la fortaleza del capitalquienes a su vez, fijan los precios del mercado mediante reglas del juego producto del proceso político del monopolio y del oligopolio del mercado nacional e internacional y que en ultimas, conduce a la desigualdad política que pretende el Estado social de derecho corregir, cuando las aspiraciones de egresos son superiores a los ingresos, como fuente de acceder a bienes y servicios en una sociedad de mercado frente a la variable del empleo y los bienes de producción. Este enfoque estructuralista es objeto de crítica por parte de los análisis funcionalistas del Estado.

Por esta razón el autor en cita, expresa:

"La consolidación de la gobernabilidad democrática y el funcionamiento de las fuerzas del mercado requieren de un sistema judicial independiente, confiable, fuerte, eficiente, equitativo y moderno que no solo asegure un ambiente de inversión y crecimiento, sino también sea una garantía de legitimidad 
a la hora de asegurar el acceso a la justicia y la protección de los derechos fundamentales a los ciudadanos". (Carrillo, p 38).

Al respecto Amartya Sen en su libro "La idea de la Justicia", considera que la mayoría de campeones de la democracia han sido más bien reticentes en sugerir que ésta promovería el desarrollo y la mejora del bienestar social donde existen serias tensiones entre democracia y desarrollo.

Por esta razón, existen democracias que se han inclinado por buscar más riqueza o crecimiento económico que democracia. Los tigres asiáticos o la china revolucionaria son ejemplos que han enrumbado las democracias hacia el crecimiento económico sin divorciarse de los derechos y libertades de sus ciudadanos y han conservado el patrimonio de las revoluciones socialistas como garantía de derechos mínimos a los ciudadanos.

Sobre este importante tema, debemos destacar que tenemos que ir más allá que el crecimiento económico, para entender las exigencias del desarrollo y de la búsqueda de la justicia social que demarcan las políticas macroeconómicas y donde al parecer incide una figura jurídica como el Incidente de Impacto Fiscal que se desarrolla a lo largo de la investigación.

Tenemos en consecuencia que la democracia y la ampliación de derechos civiles y políticos enriquecen las libertades de otras clases, como la seguridad humana, propuesta por las Naciones Unidas desde 1994, para los países pobres y o en conflicto armado como Colombia 
donde existen gobiernos de mayorías, pero que no se protegen los derechos de las minorías y de los más vulnerables.

De esta forma, se propicia así el agrietamiento del conflicto social y económico donde la búsqueda de la justicia social a cargo de los gobiernos y la distributiva en cabeza de los jueces, siguen en el orden del día, sin mayores indicadores de mejoría en el sistema democrático con estándares de calidad de vida y garantía de derechos y allí comienza la relación armónica de acuerdo con la autonomía constitucional de uno y otro para la garantía de derechos y en el cual el Incidente como veremos es solamente un instrumento.

En este orden de ideas, es necesario precisar las siguientes definiciones en materia jurídica de conformidad con nuestra jurisprudencia y la doctrina:

Estado constitucional de derecho: la Sentencia SU-747 de 1998 determina que:

"La acepción Estado de derecho se refiere a que la actividad del Estado está regido por las normas jurídicas, es decir que se ciñe al derecho. La norma jurídica fundamental es la Constitución, lo cual implica que toda la actividad del Estado debe realizarse dentro del marco de la última. En esta situación se habla entonces de Estado constitucional de derecho". (p.1).

Principio de Estado Social de derecho: Es"realizar la justicia social y la dignidad humana mediante la sujeción de las autoridades públicas a los principios, derechos y deberes sociales de orden constitucional" (Colombia, 2001, p. 1). "Supone la adopción de políticas sociales que normalmente sólo a través del principio democrático" (Colombia, 1995, p ,1). El papel del Estado Social de Derecho 
consiste, así, en "crear los supuestos sociales de la misma libertad para todos, esto es, de suprimir la desigualdad social” (Böckenförde,2000, p. 37).

De otra parte, la Sentencia SU-747 de 1998 expone:

“Con el término social se señala que la acción del Estado debe dirigirse a garantizar a los asociados condiciones de vida dignas. Es decir, con este concepto se resalta que la voluntad del Constituyente en torno al Estado no se reduce a exigir de éste que no interfiera o recorte las libertades de las personas, sino que también exige que el mismo se ponga en movimiento para contrarrestar las desigualdades sociales existentes, para ofrecer a todos las oportunidades necesarias y desarrollo de sus aptitudes y para superar los apremios materiales" (Colombia, 1998, p.1).

Principio democrático: Según señala la Sentencia C-566 de 1995 corresponde a "Las demandas por bienes y servicios formuladas por las personas, los grupos, las asociaciones, los partidos y demás formas de acción y cohesión social, se hacen presentes, compiten y se tramitan a través de los distintos mecanismos, directos e indirectos, de participación democrática. La distribución del producto social es esencialmente un asunto político, máxime si entraña gasto público y supone el ejercicio de la potestad tributaria enderezado a arbitrar los recursos para realizarlo”. (p. 1)

"Frente a esta realidad jurisprudencial que postula la naturaleza y elementos del Estado social en Colombia, también es cierto mencionar que “...la excelencia de una Constitución no se determina por las intenciones que la inspiraron, sino por los efectos que sus instituciones producen al ser aplicadas en la realidad”. (Núñez, p 8). 
La Sostenibilidad Fiscal, a su vez se define como

“...la capacidad de un gobierno para atender el pago de su deuda a largo plazo. Por consiguiente, un gobierno con un determinado saldo de deuda viva tiene que obtener superávits primarios en el futuro, y estos han de ser suficientemente elevados para hacer frente a las obligaciones de pago(actuales y futuras) de su deuda. En otras palabras, la sostenibilidad fiscal exige que el gobierno sea solvente, es decir, que pueda rembolsar su deuda en algún en el futuro.

Así pues, una situación es sostenible cuando se cumplen dos condiciones, a saber: (i) cuando un país puede satisfacer sus restricciones presupuestales en el periodo actual sin recurrir, por defecto o exceso, a la monetarización de su deuda; y (ii) cuando un Estado no sigue acumulando deuda, a sabiendas de que un futuro ajuste mayor será necesario, en orden a lograr satisfacer el servicio de aquella.

...en definitiva, según la doctrina, la sostenibilidad fiscal es un asunto que concierne la estabilidad macroeconómica de un país, su crecimiento a largo plazo, al igual que su capacidad para asumir su deuda pública.

Así entonces, las finanzas públicas de un país son sostenibles, en la medida que el implica que la política fiscal debe estar orientada en el largo plazo a la generación de ahorros (superávits primarios) que garanticen honrar la deuda pública" (Lozano, I. E. 2010).

La definición conceptual que antecede, nos plantea de entrada los retos para la materialización del Estado social cada vez más requerido en garantía de derechos por parte de los ciudadanos o gobernados que puede ver relativizados sus derechos por razones macroeconómicas y donde incide de manera fundamental, la doctrina neoliberal y sus manifestaciones económicas,de 
conformidad con un enfoque estructural con la cual dimos entrada a la presente tesis desde la doctrina internacional.

Visto todo lo anterior como precisión conceptual, nos adentramos en la conceptualización del Estado social frente a la figura jurídica de la Sostenibilidad Fiscal y su Incidente de Impacto. 


\section{CAPÍTULO 1}

\section{EI Estado Social y Democrático de Derecho y Jurisprudencia sobre el Incidente del Impacto Fiscal.}

\subsection{Referencia Doctrinal}

Para dar respuesta a las inquietudes conceptuales que anteceden, es menester acudir a la doctrina para ubicar conceptualmente los términos del Estado social. Por razones metodológicas al final damos paso a las concepciones del Estado fiscal como figura jurídica-constitucional que se plantea ante las realidades macroeconómicas del Estado colombiano donde el incidente de sostenibilidad fiscal se constituye como veremos en un instrumento importante para su presencia en la realidad constitucional y administrativa.

El derecho es un término medio entre la anarquía y el despotismo; trata de crear y mantener un equilibrio entre esas dos formas de vida social. Para evitar la anarquía, el derecho limita el poder de los individuos particulares; para evitar el despotismo frena el poder del gobierno, es decir desarrolla el derecho privado y el derecho público y crea restricciones al ejercicio arbitrario e ilimitado del poder. (Bodenheimer, 1964, p. 26)

"El mejor modo para acercarse a la experiencia jurídica es aprehender los rasgos característicos y considerar el derecho como un sistema de normas o reglas de conducta" (Bobbio, 1985, p.87) 
Llamase también derecho una prerrogativa o una facultad que pertenece a una persona, para obtener un efecto jurídico en virtud de la regla del derecho; la regla del derecho es una regla de conducta que se impone a los hombres que viven en sociedad y cuyo respeto es asegurado por la autoridad pública. (Roubier citado por Naranjo, 1984, p. 6)

Los preceptos de derecho dan origen a relaciones de subordinación cuando, las personas a quienes se aplican no están consideradas como jurídicamente iguales, es decir, cuando en la relación interviene el Estado en su calidad de entidad soberana y un particular. (Naranjo, 1984, p.12).

La doctrina clásica de la soberanía de Estado consiste fundamentalmente de que en toda sociedad existe un poder absoluto, superior e incontrolado para la adopción y promulgación de las normas jurídicas que deben regir esa sociedad. Según esta concepción, el soberano no está sujeto a ninguna autoridad superior y puede emplear-de manera ilimitada-la coacción sobre quienes están sometidos a su poder. (Naranjo, 1984, p.204).

El derecho puede estar así encarnado en una persona, como ocurriría en una monarquía absoluta o en un régimen autocrático, en una pluralidad de personas, como en las monarquías limitadas o en los regímenes aristocráticos, o en todo el conglomerado de la población como ocurre en las democracias.(Naranjo, 1984, p.204).

El Estado como ente jurídico y político, dotado de atributos que le son propios, particularmente el de ser un poder soberano, no es un organismo estático, sino que tiene que cumplir determinados fines, los cuales constituyen su propia justificación. Estos consisten fundamentalmente en la búsqueda del bien común, esto es, en la satisfacción de 
las aspiraciones e intereses colectivos y permanentes de la comunidad. (Naranjo, 1984, p.227).

Para lograr la realización de sus fines, el Estado tiene, pues, necesidad de actuar, de ejercer determinadas funciones. Por funciones estatales se entienden en derecho público, las diversas actividades del Estado en cuanto constituyen diferentes manifestaciones o diversos modos de ejercer el ejercicio de la potestad estatal. Poder del Estado que es indivisible...(Naranjo, 1994, p.227).

De acuerdo con estas referencias doctrinales y la realidad de expresión del Estado en Colombia y de conformidad con los doctrinantes inicialmente descritos en acápite inicial, el Estado social de derecho, es o parece ser, de ahora en adelante, apenas un adorno lingüístico dentro de un conjunto de normas que hace prevalecer el factor económico -cuyo contenido es impactado negativamente por las políticas económicas nacionales e internacionales y particularmente sobre la dignidad humana, los derechos fundamentales, los derechos sociales, los derechos colectivos y del ambiente, el acceso de toda la población y en especial la de menores recursos - a los bienes y servicios básicos como expresión de democracia constitucional en especial frente a la sostenibilidad fiscal que de alguna manera plantea un recorte presupuestal para su garantía mediante un enfoque funcionalista útil para las administraciones públicas de los gobiernos.

El desarrollo de la tesis se encarga de sustentar esta premisa frente a un modelo económico sustentado a ultranza en los factores del libre mercado con amplia ausencia de intervencionismo estatal como lo pregonaba Keynes. 
En este aspecto es importante en primera instancia acudir al tratadista Ferdinand Lasalle ya citado y quien se ocupa de esta materia de la siguiente forma y que coincide con el desarrollo temático que nos hemos propuesto:

...los problemas constitucionales no son, en última instancia problemas de derecho, sino de poder, y que la verdadera Constitución de un país reside en los factores reales y efectivos de poder imperantes en la nación; sus palabras quedarán siempre como modelo de elocuencia auténtica y verdaderamente popular"“....es el conflicto entre el derecho meramente escrito en el papel y los factores de poder esculpidos en el bronce de la realidad. (Lasalle, 2010, p. 22 y 86).

Estas afirmaciones doctrinarias precitadas, constituyen en su conjunto el marco teórico del derecho público y la expresión del derecho o de las normas que están sujetas a la realidad del poder, y de allí se parte como premisa necesaria para el desarrollo conceptual del Estado, del Estado Social de Derecho, de la Democracia y del Derecho en general, respecto de los objetivos generales y específicos que pretende la tesis, cuando se afirman amenazas y retos a la formulación del Estado y sus expresiones como la soberanía territorial y la soberanía popular en procura del interés general ante las expresiones del libre mercado que igualmente tutela y protege el Estado según los enfoques teóricos dispuestos para el análisis propuesto.

\subsection{Referencia Jurisprudencial}

Expresa la sentencia C- 566 de 1995 de la Honorable Corte Constitucional: 
El Estado social de derecho se erige sobre los valores tradicionales de la libertad, la igualdad y la seguridad, pero su propósito principal es procurar las condiciones materiales generales para lograr su efectividad y la adecuada integración social. A la luz de esta finalidad, no puede reducirse el Estado social de derecho a mera instancia prohijadora de bienes y servicios materiales. Por esta vía, el excesivo asistencialismo, corre el riesgo de anular la libertad y el sano y necesario desarrollo personal.

La función distributiva de determinados bienes y servicios culturales y materiales por parte del Estado, se apoya fundamentalmente en el ejercicio de la potestad tributaria y tiene, por ende, un límite en la capacidad de exacción del sistema fiscal, el cual a su turno depende del nivel y del crecimiento de la economía. No es, pues, ilimitado, el poder del Estado social de derecho de captar ingresos y convertirlos en recursos fiscales.

"El orden jurídico que fija reglas y procedimientos está al servicio de la realidad" (Núñez, pág. 8).

La necesaria distribución del producto social, no puede traducirse en la destrucción del proceso económico, cuya dirección de otra parte se confía al mismo Estado. Igualmente, por idénticas razones, la gestión del Estado en su ámbito prestacional, deberá caracterizarse por su eficiencia, economía, eficacia y conducción al interés general como respuesta al Estado Social o de bienestar Keynesiano.

El avance del Estado Social de Derecho postulado en la Constitución, no responde al inesperado triunfo de ninguna virtud filantrópica, sino a la actualización histórica de sus 
exigencias, las cuales no son ajenas al crecimiento de la economía y a la activa participación de los ciudadanos y de sus organizaciones en el proceso democrático. (Corte Constitucional, 1995, p1)

Por lo expuesto y de conformidad con la jurisprudencia citada, en principio podemos afirmar que la Constitución Política de 1991, a sus 26 años de vigencia,ha sufrido una mutación fundamental.

Tan fundamental que, a partir de ahora, al parecer tenemos percepciones de que estamos en presencia de otra Constitución, cuando se advertía un modelo estrictamente social y pacifista, incluso como expresión de un modelo socialdemócrata.

La realidad, es muy distinta. Es otra Constitución que a su vez apeló a la defensa del modelo capitalista. Esta fue la Constitución que fuera aprobada por los delegatarios a la Asamblea Nacional Constituyente y los postulados de la democracia constitucional inicialmente citada, la desarrollamos a continuación en virtud de que las normas superiores no se han cumplido integralmente.

El avance de los regímenes regulatorios, las agencias internacionales y las políticas sancionadas por medio de tratados, solo han podido existir porque el enunciado filosófico del Estado-Nación, ha acordado crearlas, confiriéndoles legitimidad, pero a su vez, cede parte de su soberanía territorial y popular. 
En este aspecto esa Constitución de 1991 que fortalecía el Estado Social y sus diferentes expresiones, ha dado pasos a la multilateralización en la cual se funda el concepto del Estado Global que la escuela estructuralista vista no comparte y que los funcionalistas pregonan para efectos de nuestro análisis coherente de desarrollo conceptual.

¿Ha vencido el poder económico al poder ciudadano donde el poder Estatal no ha mediado el contenido social Constitucional en desarrollo de construcción como modelo de democracia Constitucional?

Es la pregunta que surge cuando en el enunciado constitucional consagró el Estado Social, pero que a su vez, posibilitó un modelo económico fundado en la empresa privada nacional e internacional. Esta unión para los estructuralistas es crítica y para los funcionalistas es útil para las finanzas públicas de la administración.

En efecto y de manera inicial podemos advertir queal parecer no existe duda de que el poder económico es preeminente en el modelo político y económico imperante en Colombia.

Partimos de estarealidad en el contexto de Estado vigente y en la expresión de democracia de Colombia, como respuesta y absolución a la pregunta que antecede y como correspondencia a las iniciales reflexiones doctrinales y jurisprudenciales, que sirven de referencia necesaria a la metodología de la tesis, que en su desarrollo justificará la premisa en cita y a las conclusiones de la misma. 
De la lectura del texto "Manifiesto por una justicia constitucional responsable" de Antonio José Núñez, igualmente planteamos los siguientes interrogantes que en el desarrollo temático procuramos absolver:

¿El artículo $1^{\circ}$ de la Constitución Política es una simple retórica constitucional?

¿El orden jurídico que fija reglas y procedimientos está al servicio de volverlo realidad?

¿Asegurar los derechos pertenece al mundo de la economía, del derecho o de las autoridades instituidas para materializarlo?

¿La variable del ingreso nacional que promueve el aumento de la riqueza nacional es el medio más seguro para garantizar los derechos?

¿Los derechos llegan lejos solo si lo permite el desarrollo económico?

¿Lo que produce riqueza no son las normas sino la actividad productiva?

¿La justicia constitucional es un instrumento eficiente para la materialización del Estado social de derecho?

¿La justicia constitucional queda ampliamente en manos de los peticionarios, mientras que los costos se reparten entre toda la sociedad? 
¿Tiene viabilidad en la Colombia del Estado social, las premisas de Robert Alexy que pregonaban el racionamiento de los recursos disponibles?

¿El racionamiento de los bienes privados da lugar a la corrupción?

Para dar respuesta a las anteriores interrogantes, proponemos el desarrollo de los siguientes acápites.

\subsection{Principio del Estado Social de Derecho/Principio Democrático}

Se torna visible la interdependencia que existe entre el principio del Estado Social de Derecho y el principio democrático. El primero supone la adopción de políticas sociales que normalmente sólo a través del segundo se establecen.

Las demandas por bienes y servicios formuladas por las personas, los grupos, las asociaciones, los partidos y demás formas de acción y cohesión social, se hacen presentes, compiten y se tramitan a través de los distintos mecanismos, directos e indirectos, de participación democrática.

La distribución del producto social es esencialmente un asunto político, máxime si entraña gasto público y supone el ejercicio de la potestad tributaria enderezado a arbitrar los recursos para realizarlo en procura de desarrollar el Estado Social de Derecho, de conformidad con el artículo 
350 de orden constitucional que prioriza el Gasto Público Social. (Constitución Política de Colombia, artículo 350)

Bien entendido, el liberalismo político promueve que la esfera pública (el poder político) deje respirar a la esfera privada (económica e ideológica) con la finalidad precisa de limitar los poderes (públicos y privados) para proteger los derechos de la libertad. Y si consideramos que el poder económico también puede concentrarse hasta convertirse en un poder absoluto, tenemos que el liberalismo político podría implicar límites a las libertades económicas. Cuando el poder económico se concentra en unas pocas manos, las cuatro libertades de los modernos están en peligro.

El liberalismo político se opone a la confusión entre las diferentes esferas del poder, pero, sobre todo, combate la concentración absoluta de los poderes en cada una de esas esferas, es decir, la concentración del poder político, económico o ideológico. (Salazar, 2006, p.82)

La cuestión social está hoy en el centro del debate público. Los movimientos sociales a los cuales dedicamos acápite aparte, suceden en todos los sectores del mundo compuesto por países satélites y periféricos influidos por la globalización de la economía y confrontan las políticas que poco a poco ha venido consolidando al Estado Global en defecto de los EstadosNación de inicios de la república como factor real de poder y pueden constituir un espacio de defensa de los elementos y naturaleza del Estado social de derecho que pueda verse amenazado por factores como la globalización o el neoliberalismo que impulse a las políticas nacionales a utilizar la Sostenibilidad y el Impacto Fiscal. 
Para procurar una conceptualización en la materia, es menester acudir a una contextualización del fenómeno social y político de orden mundial con presencia en el ámbito nacional a través de la protesta social en procura de reformular las políticas públicas que amenazan los derechos sociales, económicos y culturales que afectan la libre asignación de bienes y servicios para los sectores más desprotegidos de la sociedad colombiana.

Seattle en Estados Unidos, Seúl en Asia, Génova en Europa, las marchas campesinas, las protestas estudiantiles, de trabajadores de la salud, el agro y la educación, entre nosotros, el Foro de Porto Alegre, son acontecimientos que tienen todos un mismo hilo conductor.

No hay que hacer mucho esfuerzo para captar que, a nivel planetario, en el fondo y en el centro de controversias las contradicciones, el juego o rivalidad de poderes, los diversos enfoques culturales, los campos de confrontación o de confluencia, está al presente el asunto primordial de la vida, el desarrollo y la soberanía de los pueblos.

Como consecuencia del giro hacia la globalización neoliberal que ha tomado la economía y la política mundial en las dos o tres últimas décadas, millones de personas y centenares de pueblos luchan hoy denodadamente por sus derechos económicos, sociales y culturales, que los Estados se encargan de aplazar en términos de progresividad por razones fiscales, como el caso colombiano. El paradigma de los derechos humanos integrales sirve de referente utópico, tras la caída del muro de Berlín, para la nueva ola de protestas y proyectos de los excluidos de la tierra.

Las tensiones colombianas son parte de las tensiones regionales y mundiales en el contexto de la nueva guerra fría entre el norte y el sur, entre el desarrollo y el atraso, entre el centro 
y la periferia, entre pos modernidad y pre modernidad. La que podríamos llamar agenda Colombiana de hoy coincide en gran parte con la agenda mundial: drogas, ambiente, derechos humanos, desarrollo humano, Estado-nación, papel de los organismos internacionales tanto económicos como políticos. (Díaz, 2001, p.9).

Por ser un tema que incide fundamentalmente en la expresión y consolidación del Estado Social de Derecho frente al Estado Global, más adelante incluimos acápite especial a esta materia.

El mismo autor sobre la concepción de Constitución expresa: “Aristóteles entendió a la Constitución como el principio que ordena la autoridad organizaba las magistraturas, la distribución de los poderes y los atributos de la soberanía”, es decir, el modo de ser de la ciudad.

Tradicionalmente se ha entendido la Constitución como el reflejo de la infraestructura social de un pueblo en una normatividad, cuya vigencia se apoya en una realidad subyacente. En otras palabras-según Lorenz von Stein, 1815-1890- es la forma en que la pluralidad de la voluntad del pueblo se configura en voluntad unitaria del Estado, o como lo señala Ferdinand Lasalle, 1825-1864, es la suma de factores reales de poder que rige un país.

Otros autores consideran simplemente que la Constitución, "Es el conjunto de reglas relativas al gobierno y a la vida de la comunidad estatal, desde el punto de vista de la existencia fundamental de ésta; ley vital, norma o realidad integradora del Estado, es decir, “Orden jurídico del proceso político". (Díaz, 2001, p. 24 y 25). 
De conformidad con la doctrina en cita, la teoría constitucional contemporánea corresponde a la teoría jurídica de la democracia. Como respaldo de esta afirmación, es necesario recorrer las diferentes opiniones de doctrinantes en la materia y a los más importantes y ya citados, en contexto con el desarrollo conceptual de lo propuesto en la presente tesis.

En consecuencia, es imposible separar la concepción de Estado de Derecho o Estado Social de Derecho del concepto de la democracia. No se podría entender la organización y el funcionamiento del Estado del poder constituido de la soberanía del pueblo o la soberanía popular de conformidad con el artículo $3^{\circ}$ previsto en la Constitución Política, cuando expresa que la soberanía reside exclusivamente en el pueblo, del cual emana el poder público. Hoy la soberanía está fundamentalmente en cabeza de las decisiones del poder constituido frente al Estado Global, es decir, es la imposición del poder económico sobre el poder ciudadano, donde las políticas macroeconómicas al mejor estilo del Consenso de Washington como la Sostenibilidad y el Impacto Fiscal que se podría entronizar como principio de disciplina fiscal en el ordenamiento colombiano para el recorte y limitación de derechos que para los análisis funcionalistas sería de gran utilidad.

Por lo expuesto la Democracia Constitucional es una formula lingüística exitosa, expuesta por el tratadista Luigi Ferrajoli en su obra "Diritto e ragione" que data de 1989 y que recoge con sabiduría Pedro Salazar Ugarte en su obra "La Democracia Constitucional", al cual acudiremos para fundar aún más esta relación indisoluble en el derecho público contemporáneo como sustento y defensa a los Estados Nación como expresión de soberanía de manera funcional formal. 
Esta expresión Democracia Constitucional, designa un objeto complejo: un entero sistema jurídico-político. De esta forma, nuestro propósito encuentra un fundado razonamiento jurídico respecto al funcionamiento del Estado Colombiano cuando se consagra el Estado Social de Derecho que se caracteriza por ser un Estado de bienestar con enfoque estructuralista y de responsabilidad material a los gobiernos, ya que su objetivo principal es la consecución de un nivel de vida aceptable de calidad de vida, pero que factores como la globalización neoliberal y los conflictos internos de la sociedad Colombiana, se convierten en amenazas pero a su vez en retos para el cumplimiento filosófico y jurídico constitucional vigente a partir de 1991.

El tratadista Luis Bernardo Díaz, al cual se ha acudido, se refiere a la forma de producción capitalista que se hace compatible con este objetivo (Artículo 333 C.P) y que el legislador previó para corregir las injusticias del mercado, pero se observa con preocupación que las premisas del Estado liberal han permitido su desarrollo formal, sin una real expresión pública de la intervención y de la regulación del mercado, generando de esta forma enormes desigualdades sociales y económicas, que nos presenta ante el concierto internacional como uno de los países más inequitativos del mundo y segundos en América Latina, después de Haití.

En esta materia Joseph Stiglitz al referirse al tema de la democracia del siglo XXI, afirma:

A veces un aumento en la riqueza financiera corresponde a casi nada más que un simple desplazamiento de la riqueza "no medida" hacia la riqueza media -y estos 
desplazamientos pueden, en los hechos, reflejar un deterioro en el desempeño de la economía en general. Si aumenta el poder monopólico o las empresas (por ejemplo los bancos) desarrollan mejores métodos para la explotación de los consumidores comunes, ello se mostrará como mayores ganancias y, cuando dichas ganancias se capitalizan, se mostrarán como un incremento en la riqueza financiera.

No obstante, cuando lo anteriormente descrito sucede, el bienestar social y la eficiencia económica por supuesto que caen, incluso de manera simultánea a un aumento oficial de la riqueza medida. Simplemente no tomamos en cuenta la disminución correspondiente al valor del capital humano-es decir, no tomamos en cuenta la disminución de la riqueza de los trabajadores.

Si logramos tener las reglas del juego correctas, podríamos incluso ser capaces de restaurar el crecimiento económico rápidocompartido que caracterizaba a las sociedades dela mitad de clase media del siglo XX. El principal interrogante al que nos enfrentamos hoy en día realmente no es un cuestionamiento sobre el capital en el siglo XXI. Es una pregunta sobre la democracia en el siglo XXI. (Stiglitz, 2014, p. 51).

Esta reflexión del premio nobel en economía, nos plantea de manera contundente la amenaza del monopolio del capital, la disminución de la riqueza de los trabajadores y del interés general por la ausencia de una correcta intervención de la economía para lograr la expresión del Estado Social de Derecho mediante un enfoque estructuralista y plantea de entrada un reto a la visión que debe cumplir el Estado, donde la economía en ese entorno de privilegio estaría al servicio del gran capital, y se convierte en un distorsivo para la democracia del siglo XXI al 
servicio del Estado Global donde reinan los países satélites o desarrollados como sometimiento económico a los países periféricos como Colombia.

Por estas razones la doctrina expresa:

"Las consignas neoliberales de Friedrich Von Hayeck y Robert Nozick, debe darse prevalencia al bienestar macroeconómico sobre la garantía de los derechos. Al fin de cuentas, estos terminan siendo algo casi ilusorio, totalmente dependiente del crecimiento económico" (López y otros, 2013).

“Thomas Hobbes dio la pista cuando argumentó que el hecho que el Estado sea una entidad artificial no lo hace falso o ilusorio; hay que trazar los vínculos que generan la unidad de esa entidad y permiten atribuirla a ella acciones realizadas por ciertos individuos"' (O’Donnell-2008).

De otra parte, y más adelante se acudirá a la mención de la expresión del derecho y de sus limitaciones en cuanto a la interpretación judicial, la creación legislativa dirigida al privilegio financiero y la formulación de políticas en materia económica por parte del ejecutivo, que en su conjunto contribuyen a conformar el sistema económico constitucional vigente en Colombia y que perpetúa el capital financiero sobre el capital del desarrollo humano como riqueza real de las nación.

Por ahora, podemos afirmar que la responsabilidad fundante de los gobiernos consiste entonces en la garantía de las prestaciones y servicios públicos necesarios como premisa constitucional prevista en el artículo $1^{\circ}$ de orden constitucional, para procurar el bienestar de la sociedad y ese es el anhelo de los gobiernos y de los partidos políticos que pugnan por el poder, 
pero que tienen contenciones denominadas amenazas y retos como objeto de estudio y desarrollo de la tesis, primero por enfoques constitucionales y jurídicos de orden formal y funcional y por las circunstancias del manejo de la economía globalizada.

En este aspecto tenemos que, la planificación de la economíapor parte del Estado a partir de la formulación de los Planes de Desarrollo supone un cambio importante del poder ejecutivo que incline la balanza de su gestión para el beneficio del poder ciudadano en lugar de incrementar los beneficios del poder económico que sin una regulación real constituye hoy en Colombia un sector que dirige las políticas públicas, y en especial, las políticas fiscales a las cuales volveremos al cierre de nuestro trabajo.

Esta amenaza ha generado en otros países fundamentalmente en Europa, la crisis de los Estados de bienestar a través de la globalización neoliberal que arremete y afecta la justicia social en el mundo y por esta razón, más adelante nos adentramos en el instrumento de la protesta del poder ciudadano a través de los movimientos sociales ya citados, para entender la magnitud de la crisis que igualmente golpea la sociedad colombiana.

De la misma forma, para entenderlos como instrumento importante de contención ante las falencias de control por parte de las expresiones de la democracia representativa que simboliza el sistema político, que crea las leyes y el jurídico como componente de la rama judicial imperante en Colombia con enfoques funcionalistas y formales, encargada de hacerlas cumplir, como fiel interprete del artículo 230 de orden constitucional que garantiza la autonomía de la rama judicial. 
En este orden de ideas y para ampliar la conceptualización que nos ocupa en el presente acápite para dar respuesta a las inquietudes planteadas para su desarrollo, es necesario acudir a un término que necesita explicación para una comprensión integral del tema que antecede y que se ha planteado como correspondencia al hilo conductor de la tesis.

Esa palabra se llama democracia. Inclusive la denominación del Estado social de derecho es ampliado a la conceptualización del Estado social y democrático de derecho.

Es quizá una de las palabras más utilizadas en el lenguaje político desde los griegos y Colombia no es la excepción desde la constitución de República. Por esta razón, la misma tesis ha acuñado una expresión adicional al Estado social de derecho, cuando se alude al Estado Social y Democrático de Derecho.

Se hace de manera premeditada para indicar que no solo basta con el enunciado jurídico previsto en el artículo $1^{\circ}$ constitucional, sino que es necesario que ese Estado se manifieste y se exprese de forma democrática como poder del pueblo, y correspondiente con los principios de igualdad, libertad y sus diferentes expresiones a través de la democracia representativa, la democracia participativa y la recientemente denominada por los filósofos pos modernos como el filósofo y tratadista alemán Jurgen Habermas, como democracia de deliberación o deliberativa, que es la expresión del verbo "deliberar" y el sustantivo derivado "deliberación" donde las decisiones ya no corresponde a un ciudadano o grupo de ciudadanos por un sistema de mayorías, sino a una decisión colegiada que es casi que inexistente en el sistema político colombiano. 
De otra parte, en los discursos sobre la democracia aparecen otras acepciones y que son conocidas como la democracia formal o la democracia de normas; la democracia sustancial o material, es decir que esa formalidad se materialice. En este orden de conceptos es importante señalar la correspondencia en su orden de los enfoques estructurales y funcionales a los cuales se han hecho referencia; y de la existencia también de la democracia liberal occidental y de la democracia socialista u oriental, como vestigios de la composición política de la época denominada de pos guerra de mitad del siglo XX, luego de la composición global de orden político luego de la Segunda Guerra Mundial como ya se citara en nuestro acápite introductorio.

De esta manera, es necesario expresar para llegar al modelo de democracia imperante en Colombia, representa una forma de gobierno bajo unas ciertas condiciones que se llaman reglas del juego a las cuales Norberto Bobbio definía como "universales procedimentales" (Salazar, 2006, p. 32).

Este modelo indica hacia donde se dirige y cómo se instrumenta una decisión política, es decir, como se expresa la relación entre el derecho y el poder, para lograr la igualdad y las libertades para que sean compatibles con la esencia del Estado previsto constitucionalmente.

Si esas reglas se aplican con correspondencia de los ciudadanos, entonces esa colectividad se considera como democrática, con criterios de inclusión, equidad, pluralismo y eficiencia de los derechos que son presupuestos necesarios de la democracia, sin ser los únicos, pero si los más importantes. 
En suma como lo ha señalado Bobbio

“...la función de la democracia es la de producir decisiones colectivas con el máximo de consenso crítico y con el mínimo de imposición”. (Salazar: 2006:29).

Ese es otro reto de construcción en el sistema político y jurídico colombiano a través de la expresión del Estado social y democrático de derecho.

Por lo dicho, las concepciones de constitución y democracia son interdependientes y la definición de una depende de la otra. Como el derecho y el poder, que siempre comportan vasos comunicantes en la expresión de Estado.

Para nuestro caso, en Colombiase ha acudido a untipo de democracia que podemos definircomouna democracia formal, funcional, imperfecta y en construcción, frente a las amenazas de las lógicas de la globalización, la economía de mercado y los diversos conflictos que perviven en la sociedad colombiana y que planteamos como los grandes retos del paradigma del Estado Social y democrático de Derecho, consistente en la reivindicación y tutela de derechos sociales y económicos que para aproximar a nuestra investigación, debe confrontar la figura sumada al orden constitucional de Sostenibilidad e Impacto Fiscal como fórmula funcional de realización o de amenaza de materialización real de derechos desde un enfoque estructuralista.

Es particularmente desafortunado el caso de ciertas democracias a las que les tocó el destino de nacer como democracias aparentes: recién alcanzado un nivel(más o menos) 
aceptable de garantía de las condiciones de la democracia, han sufrido el peso de circunstancias planetarias objetivas que hacen muy difícil enfrentar el inmenso problema de las precondiciones (sobre todo) sociales de la misma y/o han salido vencedoras las propuestas políticas que se dirigen en sentido totalmente contrario. Pero no menos lamentable es el caso de aquellos países que están vaciando desde su interior los presupuestos de la democracia. (Salazar, 2006, p. 43).

La tesis pretende proponer una convicción de fondo, a través de la promoción en serio de la democracia que quiere expresar el Estado social y democrático de derecho en Colombia y para ello, es necesario entender las tensiones que generan las amenazas y retos que aquejan la insular democracia constitucional, existente donde se incluye el principio de la sostenibilidad y el incidente de impacto fiscal como parte importante de ese cuerpo jurídico del Estado y las amenazas de la globalización de la economía desde un ángulo estructural ya tratado.

Ya en la historia reciente y antigua, las insulares expresiones de democracia han sido sitiadas por gobiernos que han querido consultar estilos políticos que beben en la fuente del absolutismo y de la autocracia y que a su vez son los enemigos en el propio patio de una democracia más incluyente.

Por lo expuesto, nuestra historia demuestra quela construcción de democracia ha tenido que confrontar inmensas dificultades. Se ha partido de divisiones en el mundo político en la sociedad frente a modelos que han consultado más un modelo de totalitarismo a través de caudillos del cual dependa toda la responsabilidad del Estado. 
Por ahora, el Estado social y democrático de derecho consagrado en Colombia, consultó un modelo de democracia constitucional inspirado en la Carta de las Naciones Unidas, la Declaración Universal de los Derechos Humanos de 1948 y la Convención Europea de los Derechos del Hombre de 1950, y consagró un ordenamiento constitucional político-jurídico del pensamiento político moderno, pero que los gobiernos la han materializado en derechos, bienes y servicios como una obligación formal y funcional de las administraciones de los gobiernos en los últimos 26 años.

Limitar el poder político y distribuirlo en los ciudadanos y las dos responsabilidades siempre se han cumplido parcialmente, o mejor, formalmente.

Detrás de estas finalidades descansan los derechos fundamentales que integran la colectividad política y en suma recoge la mejor forma de gobierno, aunque ya Winston Churchill, afirmara en su época que era el peor sistema político.

Lo cierto es que nuestro modelo político dedemocracia no ha cumplido satisfactoriamente, lo cual hace pensar al ciudadano, que el mejor modelo es el totalitarismo del líder donde descansa la totalidad de la responsabilidad del Estado en su conjunto y ha sido el populismo donde han descansado las políticas públicas como esperanza del pueblo en el gobernante en un régimen fuertemente presidencialista.

Los vientos que soplan respecto a este modelo político frente a las amenazas descritas que atentan contra la esencia de la democracia constitucional colombiana del Estado social de 
derecho no son los mejores y los mandatarios cada vez obtienen menos respaldo popular de legitimidad.

Por esta circunstancia, la tesis no propone auscultar las amenazas más estructurales que se ciernen para el caso colombiano, por la delimitación metodológica y en consecuencia no pretende abarcar la totalidad de las causasde diferente naturaleza que existen en la convulsionada sociedad colombiana que responde a causas estructurales propias de la ciencia política que no es nuestra preocupación metodológica.

Avanzaremos en consecuencia y vistas las amenazas del sector económico que influyen de manera decisiva en la inequidad y la pobreza,en las consideraciones de la globalización neoliberal como otro instrumento de desigualdad y en el tema de la sostenibilidad fiscal en Colombia y sus desafíos frente al Estado social y democrático de derecho, como causas de análisis de los próximos capítulos.

\subsection{La Sostenibilidad y el Incidente de Impacto Fiscal}

Finalmente en este primer acápite conceptual, es importante referirse a las consideraciones del Incidente de Impacto Fiscal de acuerdo con la jurisprudencia constitucional a través de la Corte Constitucional, inicialmente mediante las sentencias C-288 de 2012 y C-1052 de 2012.

En estas sentencias la Corte realiza un análisis de sus elementos respecto del artículo 334 constitucional. 
Su desarrollo le pertenece al Congreso de la República, como en efecto se dio a través de la Ley 1695 de 2013 que fuera declarada constitucional por parte de la Corte Constitucional mediante las sentencias C-288 y C-332 de 2012.

De otra parte, la legitimación para promover el Incidente corresponde exclusivamente a los Ministros de Gobierno y al Procurador General de la Nación, circunstancia que permite un espacio de interlocución entre los servidores públicos ya señalados y las Altas Cortes, en el cual se les concede a los primeros la facultad de expresar las razones por las cuales consideran los efectos de una sentencia antes de ser ejecutoriada para observar el principio de Cosa Juzgada. Se trata de un instrumento meramente instrumental por medio del cual se pretende que las altas cortes dentro de sus competencias puedan considerar luego de adoptar sus decisiones, los efectos fiscales que pueda tener el cumplimiento de la sentencia y las invita a reflexionar sobre cómo lograr su observancia, en un contexto acorde con el criterio de Sostenibilidad Fiscal.

Esta decisión, debe motivarse máxime si la misma, es modulada o diferida, de conformidad con el debido proceso, previsto en los artículos 29 y 209 que consagra a su vez el principio de publicidad como desarrollo de la función judicial.

En consecuencia el principio de Sostenibilidad Fiscal es un instrumento orientador, donde las autoridades judiciales no están obligadas a realizar un estudio detallado sobre el impacto fiscal de sus decisiones. Este análisis le corresponde realizar a los Ministros de Gobierno y al Procurador General de la Nación cuando decidan promover el incidente. 
De la misma forma, el alcance del Incidente de Impacto Fiscal se encuentra restringido a los efectos de la sentencia y no al contenido de la providencia en si misma considerada, por virtud del principio de Cosa Juzgada Constitucional.

De esta forma, el Incidente de Impacto Fiscal no puede despojar a las Altas Cortes de su labor de adoptar las decisiones a que haya lugar a la luz de la protección de los derechos de las personas, siendo este elemento fundamental para nuestro análisis respecto a la materialización del Estado social de derecho. Con la limitación del artículo 334 Constitucional, por cuanto no puede restringir el alcance o se menoscaben los derechos fundamentales y así lo reitera el inciso $1^{\circ}$ del artículo $1^{\circ}$ del Acto Legislativo No 03 de 2011 el cual dispone que "En ningún caso se afectará el núcleo esencial de los derechos fundamentales".

Por todas estas consideraciones, el Incidente de Impacto Fiscal es un procedimiento establecido para abrir un espacio de dialogo y deliberación entre el Gobierno Nacional, el Procurador General de la Nación, el Procurador General de la Nación y las Altas Cortes, con miras a determinar el impacto de los efectos de sus sentencias en la Sostenibilidad Fiscal.

Así, de acuerdo con las sentencias C-288 de 2012 y C-1052 de 2012, "sólo los efectos de las sentencias pueden ser objeto del incidente de impacto fiscal dentro de los lineamientos que define el Estado social de derecho" Por lo expuesto, el Incidente solo procederá en el término de ejecutoria de las providencias, es decir, cuando no se han proferido autos que buscan su aseguramiento o cumplimiento. 
Finalmente, es importante destacar que la sentencia C-870 de 2014, mediante la cual se resolvió declarar exequible la Ley 1695 de 2013, analizó en extenso la garantía de los derechos fundamentales y la autonomía e independencia judicial, que son inquietudes que plantea nuestro trabajo. Concluye la Corte, que la Ley 1695 de 2013, no desconoce el enunciado y elementos del Estado social de derecho, como tampoco desconoce los principios de autonomía e independencia judicial.

De la misma forma, consideró que se preserva la independencia y la autonomía de la Rama Judicial en un contexto acorde con el principio de seguridad jurídica.

En sentencia C-132 de 2012, la misma Corte Constitucional, considero que con la expedición del acto legislativo sobre la Sostenibilidad y el Incidente de Impacto Fiscal, la voluntad del Congreso fue aquella de que todas las ramas y órganos del poder público en Colombia, actuando dentro de sus respectivas competencias, colaboren armónicamente para alcanzar un propósito o fin deseable, consistente en que se preserve la Sostenibilidad Fiscal del Restado, es decir, a efectos de evitar la ocurrencia de situaciones de insolvencia en las cuales los gastos superan los ingresos o que, en definitiva no exista forma de asumir estos compromisos.

En criterio de la Corte, se trata de un complemento al enunciado del artículo 113 Superior, según el cual los diferentes órganos del Estado tienen funciones separadas pero “colaboran armónicamente para la realización de sus fines”, entre los cuales, se encuentra, precisamente, la sostenibilidad fiscal. 
Quiere ello significar que, en adelante, la Sostenibilidad Fiscal se erige como un mandato de actuación coordinada entre todas las entidades del Estado, donde se incluyen los jueces o la rama judicial. Para ello, estos necesitan de una información adecuada y completa sobre la situación económica del nivel central de la Nación y de las entidades territoriales, para que al momento de decidir puedan contar con un criterio auxiliar para la toma de decisiones judiciales que preserven la sostenibilidad fiscal, sin que con ello, se vea como un atentado o amenaza contra su autonomíao como una intromisión, todo ello dentro de un concepto de legalidad estricta. Se trata de regular una actuación. No se trata que la Sostenibilidad Fiscal sea asimilada a un derecho fundamental o una especie de derecho colectivo. Es simplemente una actuación, armonización y coordinación de las competencias de todas las autoridades públicas, donde se incluyen los jueces constitucionales. Es el reconocimiento de que los Derechos sociales, económicos y colectivos, depende de la Sostenibilidad Fiscal.

Manifiesta la sentencia en mención, que los avances en materia de educación, salud, vivienda entre otros depende de la viabilidad económica del Estado, de preservar su capacidad de endeudamiento interno e internacional, en un mundo globalizado y afectado por constantes crisis económicas y por esta razón, nuestro trabajo está dirigido a este importante análisis que se desarrolla a continuación. 


\section{CAPITULO 2}

\section{La Globalización Neoliberal como Amenaza al Estado Social y Democrático de Derecho}

Como desarrollo de este acápite es necesario formular una pregunta sobre la naturaleza del sistema político económico del país para permitir establecer el modelo capitalista y los desafíos sociales de la democracia colombiana.

\section{1 ¿Colombia un país neoconservador o un país neoliberal?}

Esta pregunta es necesaria de absolver para establecer la conexidad entre el derecho y el ejercicio del poder, que siempre se asume luego del debate político y permitir en consecuencia nuestro análisis que se ha propuesto como objetivo de la tesis.

En política, se denomina comúnmente conservadurismo al conjunto de doctrinas, corrientes, opiniones y de sentido en la vida de los individuos predominantemente en materia económica, pese a que existe una corriente que defiende los postulados del conservatismo social.

Al parecer y acogiendo la génesis del conservatismo sobre prevalencia de estructuras políticas y económicas tradicionales o funcionales, se puede advertir que en Colombia las posiciones ideológicas más que partidistas, se afincan en el rechazo al cambio, y a favor de los intereses de la aristocracia y de los enunciados católicos de la iglesia, capitalistas en lo 
económico proclives a la libre competencia y no consideran el intervencionismo del Estado en la economía.

Esta es una discusión de dos siglos que no acaba y que aborda la temática de la tesis en dos corrientes concebida en las escuelas kelseniana y otra shumpeteriana, y ya citada, que vamos definiendo en cada acápite hasta las conclusiones que expresan los modelos político-económicos consagrados en la Constitución Política de 1991.

El título XII de la Constitución Política, consagra el régimen económico en Colombia. El artículo 333, establece que la actividad económica y la iniciativa privada son libres pero dentro de los fines del bien común. Para interpretar el cumplimiento del enunciado constitucional que antecede y que forma parte de otros seis artículos o normas que contiene el régimen económico en Colombia, es necesario despejar las siguientes inquietudes:

¿Quién en Colombia, define los fines del bien común? ¿La actividad de la rama ejecutiva, para hacer cumplir los intereses generales, los fines del Estado y el interés general? ¿La rama legislativa en la creación de las leyes beneficia de la misma forma los principios que orientan la participación y los intereses generales? ¿La rama judicial en la administración de justicia inter partes se dirige primordialmente a la protección de los derechos de los desposeídos del régimen de la propiedad privada?

Para absolver las interrogantes que anteceden, es necesario reflexionar si realmente la estructura y el funcionamiento del Estado en Colombia ha respondido a estos desafíos, o si por el 
contrario, de acuerdo con la exclusión social, política, económica y cultural existente, de la propia naturaleza del Estado social y democrático de derecho se encuentra realmente amenazada en su cumplimiento constitucional y legal ante los avances de un poder económico ampliamente consentido por un sector de la población, que antepuso los intereses privados sobre los intereses participativos, deliberativos y democráticos, que en su conjunto expresan el interés general del poder ciudadano y que a su vez, se debate ante la pobreza y la exclusión, que un país como Colombia, debe afrontar para mejorar las condiciones de vida de sus ciudadanos y para ello cabe preguntarse si una figura jurídica como la Sostenibilidad e Impacto Fiscal es conveniente o si por el contrario es una amenaza o hasta una restricción de derechos por los recortes presupuestales que ello implica a las decisiones judiciales.

"Esto no es sólo un gran desafío para la teoría y la práctica del estado; lo es también para la teoría y la práctica de la democracia, ya que las cualidades y fallas del Estado en todas sus dimensiones tienen fuerte impacto sobre qué tipo y calidad de democracia tenemos y podríamos llegar a tener; ella depende en buena medida de los grados de eficiencia, efectividad, credibilidad y filtraje que nuestros estados vayan logrando- y a veces perdiendo". (O Donnell-2006).

De otra parte, la Constitución Política igualmente consagra que la libre competencia económica es un derecho de todos que supone responsabilidades. Cabría preguntarse, ¿Quién o qué ente dela estructura del Estado ha cumplido fielmente con los propósitos constitucionales, que eviten el desbordamiento de los intereses del mercado? ¿Será que figuras como la sostenibilidad y el impacto fiscal contribuyen en la solución a esta situación económica o si por el contrario la agravan? 
Las reflexiones e interrogantes que preceden, soportan el poder económico que subyace en la estructura del Estado y lo hace prevalente frente a los gobiernos como representante del Estado y en relación con los ciudadanos que constituyen el poder público o ciudadano como ya quedó visto. Los ciudadanos tienen un derecho público e irrenunciable al Estado. No a cualquier Estado, sino a un Estado que garantice plenitud y calidad, como ancla de los derechos en un Estado social y democrático de derecho para el ejercicio de la democracia más que el horizonte normativo formal y funcional de la concepción política neo conservadora ya vista.

Un régimen político es libre cuando sus ciudadanos igualmente lo sean. La soberanía de los ciudadanos es el principio inmutable y fundamental mantenido vivo a través de los tiempos como premisa filosofal, en medio de las vicisitudes y de las manipulaciones sufridas a la concepción de democracia, como sistema político ideal para los países occidentales posrevolución francesa y americana.

La titánica lucha del hombre en las sociedades regidas por el mercado surgido en el liberalismo clásico de Adam Smith y por liberarse de las cadenas económicas y de los fanatismos populistas y asfixiantes, ha encontrado la tenaz resistencia de los poderes dominantes, interesados en "conservar" sus privilegios contra viento y marea y que da paso a una democracia de capitales más que a una "democracia social" que ha sido propuesta justamente para propiciar un clima de paz y convivencia y que en Colombia constitucionalmente fueran consagradas en 1991. 
Bastaría revisar los conflictos armados en Colombia, a propósito de la propiedad de la tierra, desde los inicios de la república hasta nuestros días, donde la función social consagrada en 1936 aún continúa sin real desarrollo y cumplimiento.

La Ley 1448 de 2011 sobre las víctimas del conflicto armado, es el asomo de un largo camino de reconstrucción del tejido social en Colombia, que hoy arroja una cifra superior a las siete millones de víctimas y que figuras como el incidente de impacto de sostenibilidad fiscal agravan aún más la "progresividad"del reconocimiento inmediato de la reparación del daño a las víctimas cifrada al año 2014 en 110 billones de pesos.

Siempre el poder religioso, el poder militar y por sobre todo, el poder económico, se ha esforzado con pleno éxito por mantener las condiciones de las reglas del juego en la sociedad colombiana de acuerdo con una estructura y funcionamiento del Estado complaciente, que ha permitido la prevalencia de la libertad a ultranza del mercado y que ha cortado las alas del poder público dirigida al fortalecimiento del poder ciudadano y a sus diferentes expresiones del Estado social y democrático de derecho, en procura de la inclusión y del respeto a los derechos como materialización de la democracia constitucional inacabada y formal ya vista.

De esta forma, ha prevalecido en consecuencia un sistema político protegido por un Estado de Derecho formal y excluyente que ampara privilegios y que acomodaron los avances del capitalismo al revestimiento de los principios de la legalidad de la norma que no consulta el sistema constitucional, y que reconfigura el Estado social en un sistema político y económico de 
corte neoconservador diferente al que pensó el constituyente del año 91 en su aspecto de defensa de derechos mundialmente reconocidos.

En los últimos veintiséis años y a partir de 1990, de forma coetánea con la sanción de la Constitución del Estado Social, ha predominado sobre los derechos ciudadanos que garantiza la democracia constitucional, las políticas de apertura y de globalización neoliberal de la economía, que trajeron consigo una concentración de capitales de manera exacerbada enrumbando el proceso económico hacia el empoderamiento financiero de los grandes trust económicos, ha beneficiado a sectores de elite de la sociedad, en detrimento de las grandes mayorías ciudadanas y en contra del paradigma constitucional del Estado social y democrático de derecho y las cifras de la economía dan estas razones.

“El nuevo Estado social y democrático de derecho promovido en la Carta de 1991 sería la expresión de un Estado más eficiente y ligado de una manera mucho más p los actores centrales de los productiva a la vida de los ciudadanos, los cuales serían a partir de ese momento los actores centrales de los procesos de cambio y crecimiento. En consecuencia, las narrativas de la ingobernabilidad agenciadas por la elite intelectual justificaron todo un proceso de vaciamiento estructural del Estado de bienestar, a la vez que promovieron un nuevo tipo de democracia fundada en la acción del mercado" (Jiménez, A pág. 29).

La estructura del Estado y su funcionamiento, se ha plegado a este sistema político y económico, donde prevalece el poder económico basado en el mercado-privado, sobre lo públicoEstatal como ya se afirmó en acápite anterior. 
Las consecuencias se manifiestan en el direccionamiento de la concentración de los rendimientos y excedentes financieros en las organizaciones trasnacionales a través de las empresas multinacionales que desbordan la teoría clásica de los Estados-Nación cuando pregonan la soberanía popular y a la cual ya nos hemos referido ante la inexistencia de conceptos clásico y teóricos como la soberanía de la nación colombiana.

En este aspecto el actual gobierno 2014-2018, plantea un sistema de gobierno concebido como la tercera vía de la Inglaterra del ex premier británico Tony Blair, conocido como la Tercera Vía, que concibe lo público y lo privado como formas alternas de concebir y formular las políticas públicas de acuerdo con la necesidad de eficiencia y eficacia para una u otra política.

De todas formas debemos entender que este concepto de la soberanía popular antes citada, no se expresa realmenteante los avances del mercado. En esa misma vía, no solo los gobiernos que representan la rama ejecutiva del poder público, apuntan a la formulación de las políticas públicas que defiendan prioritariamente lo social como inversión, sino que lo conciben como un gasto que debe re direccionarse a la inversión y a la rentabilidad económica como enfoque funcionalista del derecho y del poder.

En este orden de ideas, las labores legislativas y judiciales culminan a su servicio, en detrimento del poder público que debían encaminarse hacia el poder ciudadano y a la construcción de democracia social y democrática, según los mandatos del Estado social de derecho ya considerado en acápites que anteceden y es la amenaza de corrección por parte de los 
gobiernos del denominado pos conflicto que no se vislumbra en los planes de desarrollo que potencian la infraestructura física antes que el desarrollo humano.

A la anterior expresión y funcionamiento de las ramas del poder público, se suman los organismos de control que tratan de palear la defensa ciudadana de manera insular y precaria, donde funciona más la laxitud ante la falencia de un control social o ciudadano realmente vigoroso de acuerdo con el desarrollo constitucional del artículo 103 constitucional, potenciando de esta forma la corrupción administrativa como otra amenaza de la delimitación metodológica propuesta en la presente tesis y que desarrollamos más adelante.

De esta forma, opera de manera palmaria los voraces sistemas financieros o del corporativismo, como consecuencia de la ausencia de controles y de la prevalencia de intercambio de favores entre gobiernos y elites económicas, que culmina cogobernando lo público-estatal fe conformidad con los vientos de la globalización de le economía, y que trae como consecuencia, el real panorama en el concierto nacional de un sistema político-económico de corte neoconservador, en defecto del estado liberal, que se pensó construir con el Estado social y democrático con intervencionismo sobre la economía, que es insular e insuficiente para los poderosos, pero eficaz para las contenciones macroeconómicas que tengan como causa la garantía de derechos y para ello la Sostenibilidad e Impacto Fiscal es una gran herramienta constitucional y jurídica para las administraciones y la rama judicial en desarrollo del artículo 113 superior.

Pero económicamente es otra la mirada. 
Esta captura o cooptación del Estado y su funcionamiento por los intereses privados del mercado, se incrementa a su vez por la violencia política y económica, que constituye el conflicto social y económico necesario de construcción como reto de paz en el pos conflicto armado colombiano, como formulación de una política del Estado social encaminado a cerrar de una vez por todas el círculo del conflicto colombiano que no se ha podido cerrar en los últimos sesenta años.

Por lo expuesto, parece ser que Colombia transita por las concepciones conservadoras en lo político y neoliberales en lo económico, donde el Estado social se debate en sus expresiones para garantizar derechos, libertades y el interés general y el incidente de impacto fiscal es útil a sus políticas desde el punto de vista funcional - jurídico, como quedó visto de los análisis jurisprudenciales de la Corte Constitucional en la materia descritos en el capítulo inicial.

En el mundo de hoy, habría un neoconservadurismo, a favor de los principios liberales en la economía pero no en la política...se centra en la defensa de la nación o patria, de la familia o del modelo tradicional de claro paternalismo y religión... (Montagut, 2010, p. 1).

Frente a esta situación de crisis humanitaria ya destacada, el estado en el año 2011, promulga la ley 1448 o Ley de víctimas.

"En esta disposición, el derecho a la reparación integral de las víctimas parece tener un carácter meramente retórico y desnaturalizado, pues hay una ambivalencia entre la voluntad política hacia la 
reparación y el condicionamiento del mismo derecho a la sostenibilidad fiscal, elevada a rango constitucional en el año 2011" (López, 2013).

Por lo expuesto es necesario concluir, que la realidad de la jurídica formal no corresponde a la realidad de lo observado desde los procesos empíricos vistos, donde el poder económico y la violencia política y la corrupción administrativa en su integralidad, conforman expresiones dominantes en la estructura y el funcionamiento del Estado.

De esta forma, se hace aparecer un modelo de Estado-público, pero diferente al consagrado en la Constitución y las leyes mediante expresiones de incumplimiento a sus deberes y obligaciones de los fines del Estado Social de Derecho y especialmente respecto de los ciudadanos, que ven en sus mecanismos de participación para proteger sus derechos, unos meros enunciados teóricos del mundo jurídico, que son en su defecto cooptados y vulnerados, por cuanto el presupuesto público que es de todos, termina apropiado por unas elites y por grupos ilegales, que han reconfigurado el territorio, el sistema político y el poder económico que impide a su vez al pueblo a la producción del poder público a favor del interés general, de donde se deriva el concepto de lo Estatal-público o res pública, donde la figura jurídica de la Sostenibilidad Fiscal, que de acuerdo con lo presupuestado por instancias internacionales como la Corte Interamericana de Derechos Humanos para las victimas ya citadas se calcula en 110 billones de pesos y el presupuesto nacional apropia 7.9 billones y sometido a la sostenibilidad fiscal. 
En este aspecto la sentencia C-753 de 2013, que declara la exequibilidad de los artículos 19 de la Ley 1448 de 2011, el artículo 77 del Decreto 4664 de 2011 y el artículo 80 del Decreto 4635 de 2011, sobre la Sostenibilidad Fiscal en Reparación a Victimas, por cuanto no suponen una restricción del derecho a la reparación integral de las víctimas como resultado de la extralimitación en la aplicación del criterio de Sostenibilidad y estabilidad.

En este sentido las autoridades deberán contar siempre con los recursos presupuestales suficientes y es allí donde se presenta el esguince de incumplimiento de derechos, no atribuible a la Sostenibilidad Fiscal, sino a las apropiaciones de los recursos para atender el conflicto humanitario y en particular la reparación administrativa que es y será insuficiente según la realidad política y económica que vive Colombia.

\subsection{Equilibrio constitucional entre lo Económico y lo Social y la labor judicial frente al Incidente de Impacto Fiscal}

He tratado de demostrar hasta este acápite de la tesis, que la Constitución colombiana vigente no es neutra en su desarrollo por parte de los gobiernos y que la figura de la Sostenibilidad Fiscal en nada contribuye con el afianzamiento del poder ciudadano, sino que es un instrumento y que como el caso de las víctimas no incide de manera fundamental, al obedecer a causas macroeconómicas el déficit presupuestal y ya advertimos las razones estructurales de le economía colombiana. 
Y no es neutra, por cuanto no guarda un equilibrio proporcional entre el poder económico y el poder ciudadano, más adelante veremos las implicaciones de orden constitucional y legal en el ordenamiento jurídico colombiano.

Para volver al caso de la reparación de víctimas del conflicto armado colombiano, citado en el capítulo que precede, tenemos que decir que las actuaciones judiciales y administrativas van a estar sujetas al respeto del equilibrio fiscal y la justicia distributiva entre partes se verá igualmente afectada.

Por ello, es necesario afirmar nuevamente que la Constitución está compuesta por principios, normas y valores que reconoce derechos e impone unos deberes. De esta forma se creó toda una estructura judicial para la protección ciudadana, todo lo cual implica restricciones a las actuaciones a las autoridades económicas dada su amplia libertad en la implementación del modelo económico al ser una Constitución abierta, como lo ha reconocido la $\mathrm{H}$ Corte Constitucional en innumerables sentencias.

Hemos visto de manera reiterada en el desarrollo de la tesis, que debe existir un equilibrio entre la Constitución del Estado social como expresión de la democracia constitucional y el modelo económico y que debe buscar satisfacer ambos principios, pero en la práctica se impone la deliberación democrática de decisión de los órganos políticos que imponen el triunfo del sistema de mayorías a favor del poder económico, y que goza de normas abiertas que institucionalizó un modelo económico; pero que no prefiguró los instrumentos para llegar a las cosas deseables de las metas fijadas para materializar el Estado social y democrático de derecho y 
en ocasiones como el caso de las víctimas del conflicto el instrumento de Incidente de Impacto Fiscal no altera de manera fundamental la política económica de sostenibilidad fiscal.

Como consecuencia, tenemos que no es muy fecundo el dialogo entre los jueces constitucionales y las autoridades económicas como consecuencia de que en Colombia se protegen las libertades económicas, pero a su vez se reconocen los derechos sociales que si tienen unos instrumentos preclusivos, como los casos de la educación o la salud, que son universales, es decir para todos, sumado a que la prestación de la salud a través de particulares no lo determina directamente el Estado como su prestador, trayendo consigo la desviación de su naturaleza de derechos en mercancías.

En este aspecto, tenemos un ejemplo clásico de una constitución abierta en materia económica la constituye el New Deal en Estados Unidos en su Constitución. Ésta no sólo reconoce los derechos de libertad económica, sino que a partir de allí, constitucionalizó un modelo liberal de política económica, con el tiempo han ido reconociendo los derechos sociales a la usanza de los países socialistas.

En Colombia tenemos un control denominado leve, es decir donde el juez constitucional debe analizar si el objetivo que persigue una política es constitucionalmente admisible y si el medio para lograrlo es potencialmente adecuado para alcanzar el propósito. En consecuencia solamente las políticas irracionales son declaradas inconstitucionales. 
Si a esta situación se le suma la influencia de la economía en la labor legislativa del Congreso de la República y del Ejecutivo, al cual se suma incipientemente el incidente de impacto de sostenibilidad fiscal; tenemos el panorama completo de apertura total a las políticas económicas, donde el juez no tiene mayor relevancia y con lo único que cuenta es con la Constitución como fuerza normativa frente a la dignidad humana, los derechos fundamentales y los derechos humanos, mediante la ponderación de proporcionalidad y juicio de razonabilidad, cuando se involucran políticas económicas macro o comprometen la estabilidad fiscal como punto de convergencia entre derecho y economía,que a la postre son restringidos por razones macroeconómicas al mejor dictado del Consenso de Washington.

\subsection{Hermenéutica Jurídica Constitucional}

La H Corte Constitucional ha acometido su competencia respecto de diferentes asuntos como el referido al manejo de las finanzas por parte de las autoridades territoriales (C-579/01); restricción del derecho al incremento salarial de los servidores públicos y el gasto público social (C-1433/00, C-1064/01, C-1017/03 y C-931/04).

En todas estas sentencias, la Corte acude a la ponderación de proporcionalidad y al juicio de razonabilidad sobre la actividad del legislador, de acuerdo con los fines y medios utilizados para el logro de los cometidos estatales.

De esta manera, se ha desarrollado después de la mitad del siglo XX, una nueva corriente de interpretación constitucional conocida como el neoconstitucionalismo, superando el análisis 
hermenéutico fundado en un único silogismo, para abordar nuevos métodos hermenéuticos como los ya citados y que trasciende igualmente el método de interpretación de la tradición galileana de interpretación lógica-formal, donde se subsume lo particular a lo general, es decir para un hecho una consecuencia, prevista en la norma.

Finalmente, se llega al método aristotélico o teleológico que se caracteriza por la comprensión de los hechos de la naturaleza y de la sociedad mediante una interpretación teleológica o finalista. Es decir, a través de la correlación entre medios y fines. En este método, se parte de un silogismo practico, y debe definirse mediante una premisa mayor (los fines perseguidos) una premisa menor y unos medios que se utilizan para determinado fin, donde las conclusiones surgen de la relación entre los medios y los fines.

Ese es el fundamento del principio de la proporcionalidad y el test de razonabilidad como técnicas de interpretación del nuevo derecho constitucional, que precisan de mejor manera los impactos económicos que dio pie a este aparte dedicado a la hermenéutica constitucional frente a principios, y no solo a normas que son indeterminadas que exige la ponderación entre medios y fines además de la subsunción clásica y utilizada normalmente en el derecho privado.

De esta manera la proporcionalidad en el control de constitucionalidad en materia económica se ha dirigido hacia la estabilidad macroeconómica, la generación de empleo, la prevalencia del gasto público social, elementos indispensables para decidir sobre la constitucionalidad de una determinada regulación que debe ser plenamente justificada, 
proporcional, razonable necesaria y útil. (Sentencias C-1064/2001, C-1017/2003, C-931 de 2004).

Finalmente, es necesario precisar que le pertenece a la propia Carta establecer cuáles son los valores que se deben proteger en toda política económica. La pregunta que surge para efectos metodológicos de la presente tesis consiste en dilucidad si el principio de la proporcionalidad es el único medio indicado para examinar las políticas públicas de contenido económico y si la Sostenibilidad Fiscal limita estos avances del derecho público acorde con las interpretaciones estructuralistas o funcionalistas de los problemas sociales sometidos al escrutinio del derecho como expresión de poder,

Pensamos desde ya, que es insuficiente, y que recoge principios de democracia constitucional dirigidos a una precaria expresión de democracia representativa depositada en el Congreso de la República y de iniciativa de la rama ejecutiva en los controles macroeconómicos para evitar el déficit presupuestal, donde el ejercicio de la democracia representativa y deliberativa de los grandes asuntos de la res pública, no tienen espacio de concertación y que a través del acto legislativo 03 de 2011 se fortaleció funcionalmente en sus concepciones economicistas que nos permite el desarrollo del siguiente capítulo. 


\section{CAPÍTULO 3}

\section{Relación entre Constitucionalismo y Globalización en el Estado Social y Democrático de Derecho}

La tesis ha acudido en sus diferentes capítulos que anteceden a dos conceptos que pueden denominarse como ejes fundamentales del desarrollo teórico que se ha propuesto y que ha contribuido con el sistema jurídico contemporáneo, en defecto de los conceptos tradicionales del Estado-nación: El constitucionalismo y la globalización.

Es decir a la relación entre el derecho y la economía que justamente nos conduce al estudio de uno de sus instrumentos como la sostenibilidad fiscal en Colombia y su impacto en la formulación y materialización del Estado social y democrático de derecho.

El constitucionalismo supone la dependencia del poder político al Derecho dentro del concepto de Estado. Por su parte la globalización, contempla el acatamiento del poder político al poder económico que ha sido citado insistentemente en nuestro trabajo como instancia superior en nuestro sistema político al poder ciudadano y donde el poder del Estado ha contrario de convertirse en arbitro para amparar los derechos y las libertades contempladas en el Estado social, ha permitido la supremacía del poder económico como consecuencia de la globalización neoliberal, sometiendo a riesgo la naturaleza del Estado Social concebido como expresión del derecho y ejercicio del poder. 
Cuando se habla de "constitucionalismo" hay que empezar por aclarar que la expresión es ambigua: con esa expresión uno puede referirse tanto a un fenómeno como a la manera de conceptuar ese fenómeno, tanto a un proceso de cambio que está teniendo lugar en el Derecho, como a la forma como se consagra en el pensamiento jurídico.

Para explicarnos esta situación, es menester acudir a la concepción del constitucionalismo con el cual se ha titulado el presente capitulo.

La "Constitución" hace referencia a la estructura de un sistema político y a su funcionamiento, para nuestro caso a través de principios, normas y valores, como Estado democrático contempla la separación de las ramas del poder público y declara además de los derechos fundamentales, los derechos sociales, económicos y culturales, como desarrollo de las diferentes declaraciones universales sobre la materia y a la cual se han hecho ya referencia.

Esta característica, la define como una Constitución de tipo abierto donde los jueces en aplicación del artículo 230 constitucional les es conferido una relativa autonomía, para la toma de sus decisiones; y en la interpretación de las normas, debe acudir a la ponderación y a la razonabilidad del ordenamiento jurídico que debe obedecer en primera instancia a la carta fundamental, lo cual proyecta a Colombia como un Estado constitucional con fuerza vinculante y con influencia sobre las relaciones políticas como quedó analizado en acápite anterior que queda limitada con figuras como la Sostenibilidad e Incidente de Impacto Fiscal, como veremos más adelante. 
Los enunciados de Kelsen ya no son los mismos en los tiempos del siglo XXI. De esta forma, el derecho se entiende como un conjunto de reglas y de sometimiento del poder al derecho que es casi inexistente y se transforma en paradigmático.

Hoy las Constituciones son más que un conjunto de normas. Para el caso nuestro y como ya lo expusimos la Constitución Política de 1991 en relación con los derechos,son enunciados que hacen referencia a principios y valores, que contienen elementos importantes como la igualdad, el principio de la dignidad humana y sus nexos o vínculos respecto de la interpretación de derechos fundamentales, aspectos que caracterizan y hacen del Derecho como indeterminado.

En este sentido, es necesario volver cuando ya citamos las formas y escuelas de interpretación del derecho como competencia de los jueces y magistrados de la rama judicial en Colombia, para la garantía de los derechos de los ciudadanos, cuando expresamos que de manera infortunada no corresponde a una visión global de los servidores judiciales, que siguen anclados en un porcentaje preocupante a la escuela kelseniana y al silogismo jurídico, como quedó visto, y ello representa una constante amenaza al Estado social de derecho que en los próximos capítulos abordamos de manera amplia en la realidad política, económica y jurídica colombiana.

En ese método tradicional de interpretación se pasan por alto los análisis estructurales de ciencias afines como la ciencia política, la filosofía, la sociología, la economía, y en contrario de una interpretación aristotélica y finalista, se acude al criterio formal y procedimental de validez de las normas del Estado que le corresponde interpretar, desconociendo que esa interpretación que le otorga el artículo 230 constitucional, debe hacer el ejercicio jurídico de enfrentar la norma 
a la Constitución, para encontrar la constitucionalidad de su decisión a través de la ponderación y el test de racionalidad como ya se ha expresado frente a la Sostenibilidad e Incidente de Impacto Fiscal como una limitante en sus decisiones.

Por lo expuesto, los principios, normas y valores además de jurídicos tienen una expresión política y forma parte del Derecho. Por esta circunstancia la interpretación jurídica no puede corresponder a análisis meramente formales o normativos que llevan al desconocimiento de la argumentación jurídica o judicial.

De esta forma se traduce una necesidad por parte de la rama judicial para realizar el análisis de los derechos fundamentales, humanos y colectivos en sus sentencias y más que a la razón constitucional como apunta todo lo anterior, a la esencia constitucional y normativa que expresa el sistema constitucional y político democrático del Estado Social, a cambio del Estado de derecho de normas y además influenciado por la globalización.

Obviamente queesta interpretación judicial, es válida siempre y cuando no ocupe orbitas que no le pertenecen, en lo que se ha conocido como el poder de los jueces o por el gobierno de los hombres, a los cuales nos referimos más adelante en las conclusiones de la presente tesis.

Quienes rinden culto al espíritu de la norma y al derecho formal y procesal apuestan por el Derecho como conjunto de reglas ycomo consecuencia de la creación de la ley por parte de la rama legislativa. 
Esta interpretaciónno corresponde a la realidad del fin último de nuestra carta superior: el interés general.

Nuestro sistema constitucional de separación de ramas del poder público ordena que las normas deben ser interpretadas en la formación del derecho por los jueces a través de las comúnmente conocidas sentencias o fallos judiciales como consecuencia de la escuela del positivismo que trae consigo los principios y los valores, pero se ha visto en capítulos que preceden que lo dicho así entendido, no corresponde a la realidad y que en ultimas constituyen amenazas y retos para la preservación y expresión del Estado Social y Democrático de derecho, del cual forma parte la rama judicial, que en porcentaje importante se limitan a la observancia de la escuela finalista-constitucional, es decir, donde existe un nexo necesario entre la ley o la norma y el orden superior constitucional.

Este razonamiento, es visto más como una amenaza a su reputada autonomía formal y procedimental que hace culto a la escuela funcionalista, donde el Incidente de Impacto Fiscal es útil para sus decisiones.

En consecuencia, la estructura del Derecho no puede ser visto exclusivamente como una realidad ya dada según la escuela positivista kelseniana, sino como el resultado de la voluntad del legislador frente a una realidad política, entendida ésta como asunto de todos, no como practica partidista que trae consigo, una justificación o prohibición como norma jurídica, más que como una postura moral que salvaguarda los derechos de los asociados o ciudadanos como una estructura jurídica coherente. 
En estas condiciones, el Derecho se ve más bien como receptor de esos grandes cambios; no en el apartado de las causas, sino en el de los efectos de la globalización en sus decisiones.Es tal la fuerza de esta dinámica, que posiblemente esté provocando cierto grado de obsolescencia de instituciones jurídicas y políticas y en recorte permanente de derechos a los ciudadanos.

La idea que probablemente subyace al anterior planteamiento, consiste en que el proceso de globalización avanza a velocidades distintas en las diversas esferas de la sociedad y en consecuencia, la conciencia del fenómeno es distinta según se opere en una u otra instancia del conjunto social.

Así, por ejemplo, Laporta (2005) afirma que por lo que se refiere al Derecho de propiedad y al Derecho penal que no hay ninguna o casi ninguna globalización jurídica(...)El capital financiero puede volar por encima de las fronteras, pero la titularidad jurídica de ese capital permanece al calor del derecho estatal (...) los aspectos cruciales de la vida social y las actividades económicas de la inmensa mayoría de los individuos y corporaciones que habitan el planeta de la globalización se hallan todavía regulados por normas jurídicas domésticas.

Los grandes protagonistas del Derecho de la globalización no son ya los legisladores, sino los jueces y los expertos en Derecho que no ocupan cargos públicos: así, el Tribunal de Luxemburgo ha jugado un papel decisivo en la actual configuración del Derecho europeo y los árbitros que deciden los grandes pleitos del comercio internacional son abogados o profesores universitarios. 
Se dice, además, que con la globalización habría aparecido un nuevo tipo de Derecho -un soft law- en el que el recurso a la coacción es menos importante que en el caso del Derecho estatal: eso se vería en la tendencia a privilegiar mecanismos de resolución de conflictos (como la mediación o el arbitraje) que (frente a la jurisdicción) no parecen tener un carácter impositivo, puesto que presuponen la aceptación por las partes (que son quienes nombran a los mediadores o a los árbitros); o en la importancia de organismos como la Organización Mundial de Comercio, regido por normas y procedimientos distintos a los del clásico Derecho estatal.

En este mismo sentido, Ferrarese (2006) afirmaque el Derecho (el Derecho de la globalización) no consiste ya exclusivamente en normas (en prescripciones), sino que muchas de las pautas de comportamiento que contiene ese "soft law" tratan de guiar la conducta de manera flexible o sin pretender imponerse coactivamente: piénsese en las directivas europeas o en la importancia creciente de los códigos de ética como mecanismos de autorregulación.

Todo ello lleva, en fin, a una “difuminación” de los límites tradicionales del Derecho: no sólo en relación con la moral y la política, sino también en relación con las distinciones tradicionales entre Derecho privado y Derecho públicoo entre Derecho interno y externo. Así, elementos de Derecho privado, como la negociación o la noción de interés privado,juegan hoy un papel en el contexto del Derecho público: piénsese en los "plea bargaining” en Derecho penal o ellos lobbies, como instituciones que articulan intereses particulares, en el proceso legislativo. 
Y el Derecho comunitario limita, como se ha dicho, el Derecho interno de los Estados europeos, al tiempo que es común hablar de un "diálogo" entre las instancias jurisdiccionales y legislativas europeas y estatales; de manera que el Derecho no aparecería ya como fruto de la imposición de un superior, sino de un acuerdo producido "desde abajo".

En consecuencia, la función del Derecho no sería ya sólo (o tanto) la de prescribir, ordenar la conducta, cuanto la de facilitar formas de acción; su naturaleza no sería tanto política cuanto instrumental. (Funcionalismo).

Ahora bien, todo lo anterior puede servir como argumento para mostrar que la globalización sí que ha tenido una importante repercusión en el Derecho, transformando muchas de sus instituciones, dando lugar a nuevas formas de juridicidad, modificando las clásicas funciones del Derecho, etc., donde se incluyen figuras como la Sostenibilidad y el Incidente de Impacto Fiscal de rango constitucional.

Pero además, es muy importante no perder de vista que el Derecho no sólo ha sufrido los efectos de la globalización sino que, también, ha jugado un papel causal en el proceso; simplemente, todos esos intercambios e interdependencias que tienen lugar en el nivel mundial que definen la globalización- no serían posibles si no se hubiese contado con instrumentos jurídicos para ello y por esta razón, el derecho se convierte así en un instrumento para el ejercicio del poder de la Administración Pública. 
Sin el Derecho(o sin cierto tipo de Derecho) no tendríamos globalización, como tampoco habría habido capitalismo o mercado sin las instituciones jurídicas características del Estado moderno que han erigido en los países de influencia unas democracias de mera forma, funcionales, elitistas, tecnocráticas y delegativas, amparados en el discurso de gobernabilidad por razones macroeconómicas y donde lo social, es desplazado a un escenario de segundo o tercer nivel de discusión o de deliberación ciudadana, donde el la sostenibilidad y el incidente de impacto fiscal, es un instrumento valioso para sus intereses de interpretación.

Pues bien, en relación con la globalización, los juristas teóricos han reaccionado de maneras distintas de acuerdo, en principio, con sus orientaciones políticas. Así, los que cabría ubicar en el espectro de la "derecha política" ya vista; son también los que valoran el fenómeno (los cambios que han tenido lugar en el Derecho) en términos más positivos. Al fin y al cabo, lo que ha significado la globalización hasta ahora, es la victoria de la ideología neoliberal y en Colombia la victoria neo conservadora ya analizada es una realidad.

De otra parte el autor Hayek,uno de sus más conspicuos representantes, sostenía que el orden que podía encontrarse en los fenómenos complejos era de dos tipos: creado y espontáneo. El orden espontáneo es el resultado no buscado de un proceso evolutivo y su máximo exponente es el mercado.

La superioridad del mercado sobre cualquier otra organización de tipo deliberado se debe a la circunstancia de que aquí los seres humanos, al perseguir sus particulares apetencias (egoístas 
o altruistas), facilitan el alcance de sus metas a otras gentes que, por lo regular, ni siquiera llegarán a conocer.

Pues bien, la globalización, como habíamos dicho, significa esencialmente eso, la subordinación de la política al mercado, de la ley (o del tratado) al contrato, lo cual se plasma en el ideal de la desregulación: una economía más globalizada significa más libre de ataduras y, por tanto, menos reglamentada por normas jurídicas estatales o de Derecho internacional.

Pero conviene aclarar que la "desregulación” no quiere decir exactamente que no existan reglas o incluso que existan menos reglas que antes, sino más bien que un tipo de reglas (digamos, lasde carácter público) han sido sustituidas por otras de naturaleza privada o las públicas con preeminencia sobre el recorte de derechos como podría suceder con la Sostenibilidad y el Incidente de Impacto Fiscal, que como veremos no representa una amenaza y menos una perturbación a la garantía de derechos en la expresión del Estado social.

En contrario y desde una ideología de izquierda o interpretación estructuralista, el fenómeno de la globalización se ve con notable escepticismo.

La liberalización de la economía - la desregulación- ha ido acompañada de la falta de medidas de garantía hacia los derechos humanos, en especial, hacia los derechos sociales.

La globalización económica ha incrementado la riqueza en el mundo, pero a costa de ahondar las desigualdades entre los países y entre los individuos y de producir una degradación 
del medio ambiente que puede tener efectos irreversibles para las futuras generaciones según datos del informe del milenio de las Naciones Unidas.

Y, en fin, el Derecho de la globalización es claramente un Derecho no democrático; la pérdida de soberanía de los Estados ha supuesto un retroceso de la democracia, precisamente porque el ámbito en el que ésta ópera es el ámbito del Estado.

Y si la situación es ésta, entonces es lógico que se sea más bien pesimista a la hora de sugerir alguna salida a la misma. Es bastante sintomático que para dar cuenta de la actual situación del mundo globalizado se recurra con frecuencia a Thomas Hobbes y a su descripción del Estado de naturaleza, como aquel en el que prima la ley del más fuerte pero en el que ni siquiera este último puede estar seguro, puesto que el más débil puede tener fuerza suficiente para matar al más fuerte.

Veamos cuáles son las respuestas -las respuestas teóricas- que daban recientemente al problema tres de los juristas participantes en un reciente congreso mundial sobre el tema de "Derecho y justicia en la sociedad global".

Francisco Laporta, después de declarar su escepticismo con respecto a las posibilidades del Derecho global para la realización del imperio de la ley, llega a la conclusión de que sólo procesos como el de la Unión Europea parecen cumplir con los requisitos precisos para incorporar el ideal del imperio de la ley. 
La solución, por tanto, no podría encontrarse en las redes privadas transnacionales en un mundo pretendidamente anómico, sino en la construcción de unidades políticas y jurídicas supranacionales.

Pero, en su opinión, el modelo jurídico a seguir no sería exactamente el de lo que antes habíamos entendido como constitucionalismo, sino, digamos, el del Estado de Derecho más o menos clásico; un Derecho basado en reglas, procedentes éstas de una autoridad estatal o supraestatal, pero dotadas de un respaldo coactivo y que permitan asegurar las ventajas del imperio de la ley en un ámbito más amplio que el del Estado social. Es decir se privilegia la legalidad funcional del imperativo normativo.

Luigi Ferrajoli (2005), por su lado, define la globalización, como "un vacío de Derecho público" y defiende la necesidad de un "constitucionalismo mundial" (en términos no muy distintos a los de Habermas). La ampliación del paradigma del estado constitucional de derecho a las relaciones internacionales supone para él,el máximo reto lanzado por la crisis del derecho y del Estado a la razón jurídica y a la razón política, y representa además,la única alternativa racional a un futuro de guerras, de violencias y fundamentalismos.

No existen, en su opinión, razones para ser optimistas, pero no porque se trate de un programa utópico o irrealizable: simplemente no se quiere hacer porque entra en conflicto con los intereses dominantes. 
Y, en fin, Juan Ramón Capella (2005) hace un diagnóstico aún más pesimista de la situación. En su opinión, quien realmente gobierna sobre el mundo globalizado es una “tecnocracia empresarial, militar y política que viene a desempeñar el papel del Rey filósofo de Platón y de su Consejo Nocturno".

"Las instituciones democráticas se someten y subordinan a este nuevo poder imperial [del conglomerado militar-industrial; de las grandes multinacionales; de los expertos en el manejo de los capitales financieros, en la administración de las grandes industrias, en la creación de la opinión pública, en el ajuste económico, político y militar].

Día a día los procedimientos democráticos se convierten en formas desnudas de contenido, los derechos sociales se desvanecen, los derechos políticos se vuelven crecientemente ineficaces salvo en la aquiescencia al poder global. Y aparecen instituciones nuevas colocadas fuera del alcance del ejercicio de la libertad política. O reaparecen prácticas sistemáticas del poder anteriores a la modernidad: así se ve en el trato dado a combatientes vencidos, en la tortura de prisioneros, en las guerras ni declaradas, en el abandono sin remedios de enfermos y hambrientos de los países pobres.

La alternativa a ese proceso de regresión no aparece a la vista:

Tal vez sea éste un fenómeno temporal. También los años treinta y cuarenta del pasado siglo fueron décadas oscuras, como lo son éstas para numerosas poblaciones del planeta. Pero la regresión de la democracia parece ir de la mano con todo lo que 
es nuevo político-socialmente en el mundo globalizado. No hay contraejemplos nuevos que oponer a esta tendencia.

Plantearé, a partir de lo anterior, una serie de reflexiones de tesis, que no tienen otra pretensión que la de servir como base para una discusión a propósito de cuál pueda ser el papel del Derecho y de los juristas en la sociedad global frente al Estado social y la posibilidad de acción de una figura como el Incidente de Impacto Fiscal.

Cualquiera que adopte una perspectiva mínimamente realista sobre el devenir del mundo no tiene más remedio que reconocer que la globalización es un fenómeno que ha llegado para quedarse. El Derecho, en consecuencia, no será ya lo que era.

Considerarlo como un fenómeno esencialmente estatal, como un conjunto de normas establecidas por las autoridades del Estado, resulta cada vez más insatisfactorio aunque, por otro lado, esa visión sea básicamente acertada en relación con algún sector del Derecho, como el Derecho penal. Es cierto que lo que esencialmente tiene en cuenta un juez penal en el desempeño de su función son reglamentaciones de origen estatal.

Pero incluso aquí no puede olvidarse la existencia de instituciones como el Tribunal penal internacional (aunque por el momento lleve una vida más bien lánguida); el principio de jurisdicción universal reconocido por algún ordenamiento estatal (como el nuestro) en relación con los crímenes contra la humanidad; el principio de que este tipo de crímenes no prescribe, lo que ha llevado a algún tribunal constitucional a negar validez a"leyes de 
amnistía" dictadas por los Estados para garantizar la inmunidad a quienes habían estado implicados en ese tipo de acciones ${ }^{1}$; o el reconocimiento otorgado por las autoridades judiciales estatales a tribunales de carácter supraestatal como el Tribunal Europeo de Derechos Humanos o la Corte Interamericana de Derechos humanos².

En otros sectores del Derecho, la incidencia de reglamentaciones supraestatales o transnacionales es una exigencia, simplemente, de la naturaleza de las cosas. El comercio internacional, internet, los movimientos migratorios, la ecología o el terrorismo son fenómenos que no pueden regularse (o que no pueden regularse con eficacia) en el ámbito nacional y que escapan también al Derecho internacional entendido en sentido clásico.

No se trata, por tanto, de que el Derecho haya dejado de ser un fenómeno estatal, sino de asumir que la juridicidad no se agota en ese ámbito; existe también una juridicidad supraestatal (e infra estatal), cuyo peso tiende a ser cada vez mayor.

Pero, además, en la medida en que el contrato constituye la forma típica de la juridicidad en el ámbito de la globalización, el Derecho tiende, lógicamente, a verse menos como el producto de una voluntad política y, por el contrario, adquiere más importancia una visión del Derecho como un medio para obtener ciertos fines, como un mecanismo de construcción social.

\footnotetext{
${ }^{1}$ Un ejemplo interesante es el caso La Cantuta.

${ }^{2}$ En Colombia
} 
Ferrarese (2006) ha hablado, en este sentido, de un cambio de orientación del Derecho que caracteriza como el paso de una racionalidad paramétrica a otra estratégica: "Una racionalidad de tipo paramétrico tiene lugar cuando los sujetos se encuentran frente a situaciones que dependen de otros y que no pueden contribuir a redefinir o cambiar: sólo pueden configurar consecuencias distintas que derivan de la elección restringida o inelástica que tienen en frente(...).

Por el contrario, tiene lugar una racionalidad estratégica cuando los sujetos, al asumir una decisión, se encuentran en una situación de interdependencia con otros sujetos y, mientras interaccionan con ellos, deben tratar de hipotizar sus elecciones de comportamiento (Ferrarese 2006, p. 23).

La línea de desarrollo de los Derechos que representa la globalización parece ir en contra de una concepción positivista del Derecho. El Derecho, me parece, tiende a configurarse y a verse por sus operadores no tanto, o no sólo, como un sistema, como un conjunto de normas preexistentes, sino más bien como una práctica, como un procedimiento o un método para conciliar intereses, resolver conflictos, etc.

Ello supone una cierta difuminación de los límites de lo jurídico y una nueva manera de entender la función de la ciencia, de la teoría, del Derecho: no se trata tanto de describir un objeto (de manera más o menos abstracta) que está ya completamente determinado, cuanto de partir de ahí (de ciertos materiales previamente existentes) y mostrar cómo pueden usarse para operar en esa práctica y lograr determinados objetivos. 
El fenómeno de la globalización pone bien de manifiesto la creciente juridificación de nuestras sociedades y lo equivocado que resulta partir de un esquema de interpretación de la realidad social en el que al Derecho se le haga jugar un papel subordinado.

Esto, como se sabe, es lo que ocurría con el clásico esquema marxista, en el que el Derecho pertenecía a la superestructura y no a la base social (a la que se atribuye un papel determinante), y seguramente es un prejuicio que sigue operando en la cabeza de muchos científicos sociales.

El resultado consiste en minusvalorar el papel del Derecho, lo que supone riesgos tanto teóricos como prácticos. Teóricos, porque sin cierta formación de tipo jurídico es imposible entender nuestras sociedades, incluido el fenómeno de la globalización. Y prácticos, porque el Derecho es, al menos, un presupuesto para el logro de los valores más esenciales de la vida social; no tomar suficientemente en consideración los aspectos jurídicos supone poner en grave riesgo la consecución de esos valores. Naturalmente, no se trata de desconocer el condicionamiento social (particularmente económico) del Derecho.

Se trata de entender que los elementos económicos, jurídicos, culturales, etc. integran una unidad compleja dentro de la cual tiene lugar una interacción constante. Así, el Derecho -o ciertos instrumentos jurídicos- han contribuido a lo que llamamos globalización de nuestras sociedades pero, al mismo tiempo, la globalización está haciendo cambiar los sistemas jurídicos y la concepción del Derecho y la dependencia de las políticas macroeconómicas con las políticas neoliberales dan como resultado la inclusión de figuras como el Incidente de Impacto Fiscal para 
el caso colombiano, que no constituye estructuralmente una amenaza a la garantía de los derechos en el Estado social.

Una consecuencia de esa manera de ver las cosas consiste en reconocer el papel ambiguo que juega el Derecho en nuestras sociedades: el Derecho resulta esencial tanto en los procesos de explotación como en los de emancipación. La alternativa a la llamada "desregulación” no es simplemente la regulación jurídica de cierto tipo de relaciones (que, de hecho, están reguladas jurídicamente: mediante esquemas -contractuales- de Derecho privado), sino su regulación jurídica según cierto tipo de estándares morales y políticos. O sea, estamos, si se quiere, “condenados" a vivir en sociedades jurídicas, pero el Derecho de nuestras sociedades (y, por tanto, la sociedad misma) puede asumir formas muy distintas.

Y aquí es donde juega un papel fundamental la noción de derechos humanos, en cuanto conjunto de criterios inspiradores de las prácticas jurídicas. Los derechos humanos tienen su fundamento en la moral, y no en cualquier moral, sino en una de carácter universalista: negar que existan principios morales universales y de validez objetiva es, en mi opinión, un serio error, en el que ha caído un cierto pensamiento de izquierda quizás influido por estas dos circunstancias: por un lado, porque en la tradición marxista ( una tradición que se inicia en el propio Marx) la moral (y el Derecho) fue considerada parte de la ideología, de manera que propiamente no podrían existir ni verdades morales, ni ningún discurso "racional" sobre la moral que pudiera consistir en otra cosa que en "desenmascarar"su naturaleza engañosa; por otro lado, porque el lenguaje de las verdades morales y de los valores morales absolutos es el lenguaje de la religión, 
de las iglesias: el pensamiento laico, ilustrado y racionalista -se piensa- lleva necesariamente al relativismo en materia moral.

Como ejemplo de esa concepción que presenta los derechos humanos simplemente como convenciones jurídicas, desligadas de cualquier pretensión de objetividad en materia moral, puede ponerse el caso de un autor como Luigi Ferrajoli a quien, por otro lado, debe considerarse como uno de los grandes juristas del momento y uno de los mayores defensores de la “constitucionalización” del Derecho en el marco mundial.

Finalmente, si los derechos fundamentales son simplemente convenciones jurídicas, ¿por qué van a valer más allá del consenso? ¿Por qué el consenso (¿qué otra cosa es una convención?) establecido por ciertas normas jurídicas va a estar por encima de otros consensos?

Para decirlo rápidamente: el Derecho del mundo globalizado debe estructurarse a partir de ciertos principios (jurídicos) de carácter universal. Y esos principios tienen su base en una moral de carácter universal. Desligar, de la manera radical que sugiere Ferrajoli (2006), el discurso jurídico del discurso moral, me parece, un serio error y, además, un error que perjudica esencialmente al pensamiento de izquierda, empeñado en la transformación del mundo en un sentido más igualitario como resultado de un enfoque estructural de los fenómenos sociales y jurídicos.

La situación del mundo globalizado probablemente no sea sostenible a medio y largo plazo. No es nada obvio que nuestra manera de vivir (la de los habitantes de los países ricos, o la 
de muchos de ellos) sea compatible con la preservación de la vida en el planeta. Y tampoco hay por qué pensar que la actual situación en la que una minoría de individuos vive en la opulencia, mientras que la mayoría (que incluye a casi el 80 por ciento de la humanidad) padece graves carencias y que puede durar de manera indefinida.

Pero, en todo caso, y con independencia de que se pudiera o no proseguir así, lo que parece indudable es que la situación es injusta. Y que es injusta quiere decir aquí que lo es según los criterios de justicia que aceptarían si no todos, al menos una buena parte de los habitantes de los países ricos.

¿Pues cómo pensar que es justo un mundo en el que las oportunidades que se les ofrecen a los individuos dependen de manera fundamental de hechos tan azarosos como el nacimiento en una u otra área geográfica, dentro de uno u otro grupo social, familiar, etc.? ¿No va eso en contra del carácter "universal" de los derechos humanos como quiera que se entienda lo de universal?

Llevar las instituciones jurídico-políticas del constitucionalismo (las instituciones surgidas para implementar la protección de los derechos humanos y asegurar un ejercicio democrático del poder) al ámbito mundial no es precisamente una empresa fácil. Es una exigencia moral cuyo éxito (como ocurre con todas las empresas morales) no está para nada asegurado. Pero, en todo caso, una precondición para el éxito es trazarse ideas claras sobre los fines a los que se aspira y sobre los medios de los que se dispone. 
El mundo puede ser todo lo complejo que se quiera, pero la solución a algunos de sus problemas (la solución teórica) es relativamente simple. Si el mayor mal que aqueja a la humanidad es la profunda desigualdad económica entre sus habitantes, entonces lo primero que habría que hacer es procurar asegurar a todos los individuos un mínimo de ingresos, o sea, una renta básica universal, que se percibiría con independencia de cualquier circunstancia geográfica o de cualquier otra naturaleza (incluido el nivel de riqueza).

La objeción más obvia a ese tipo de planteamiento (sobre la "renta básica" se está discutiendo desde hace un par de décadas) es su falta de realismo: ¿de dónde obtener los recursos para ello? Y la contestación podría ser que de un impuesto universal que podría tener, por ejemplo, las características de la llamada "tasa Tobin".

La globalización ha contribuido, hasta ahora, a enardecer los ánimos de los avispados, y a que aumente considerablemente el número de los idiotas (en los países ricos) y de los parias (en los pobres). Pero lo que el mundo necesita, obviamente, son ciudadanos cívicos.

Y el Derecho (no cualquier Derecho, sino un Derecho imbuido de los valores del constitucionalismo) es, probablemente, uno de los instrumentos más potentes con el que cuentan para llevar a cabo la ingente tarea de civilizar el mundo y una forma es el de materializar los Estados sociales de derecho, donde el Incidente de Impacto Fiscal posibilitaría atender las exclusiones de los ciudadanos parias para beneficiar las razones macroeconómicas dirigidas a atender prioritariamente las demandas macroeconómicas de los Estados para combatir por ejemplo los efectos negativos de las finanzas públicas como la inflación económica y allí 
centraremos el análisis de la vigencia del Estado social o su simple formulación formal de normas.

"En definitiva la democracia, tal y como es entendida en el discurso neoliberal hoy día conformador de la conciencia colectiva y ordenador de las prácticas sociales dominantes, es una realidad sin posibilidad de alcanzar una sustantividad propia, y en consecuencia, incapaz de poder ser concebida en virtud de sus rasgos intrínsecos y a partir de los cuales cualquier sociedad pudiera quedar cualificada de una manera u otra” (Torres, pág. 32).

Por todas estas razones abundantes en materia jurídica, la relación entre constitucionalismo, el derecho colombiano y la globalización, es una realidad y es la causa necesaria para la inclusión en nuestro sistema constitucional, de la figura de la Sostenibilidad y el Incidente del Impacto fiscal. 


\section{CAPÍTULO 4}

\section{Antecedentes de la Sostenibilidad Fiscal,la estabilidad macroeconómica y la progresividad de los derechos- Un análisis jurisprudencial}

En Colombia el primer antecedente legal de la Sostenibilidad y del Incidente de Impacto Fiscal se encuentra comprendido en la Ley 53de 1997, por la cual se reglamenta el artículo 364 de la Constitución y se dictan otras disposiciones en materia de endeudamiento, la cual estableció límites de endeudamiento para las entidades territoriales, con el fin de que no excedan su capacidad de pago...en segundo lugar existe la Ley 617 de 2000, conocida como la ley de responsabilidad territorial, en la cual se profirió con miras a la racionalización de los fiscos departamentales, municipales y distritales y mediante la clasificación de las entidades territoriales en categorías presupuestales, el establecimiento de topes máximos para sus gastos de funcionamiento...

La Corte Constitucional examinó el sentido y razón de ser de esta regla fiscal en sentencia C-579 de 2001 de la siguiente manera:

Tales reglas fiscales, a juicio de la Corte, se ajustan a Constitución por las siguientes razones:

En términos generales, y salvo las excepciones que abajo se precisan, puede afirmarse que las medidas adoptadas por el proyecto cumplen con los requisitos arriba trazados para ser declarados exequibles. Ello por dos motivos: 
Existe una grave crisis macroeconómica, que posteriormente se verá catalizada por la situación deficitaria de las entidades territoriales, cuya estructura de gastos es una de las fuentes directas de la situación; esta situación, que rebasa la esfera propia de los intereses exclusivos de las entidades territoriales, es la que se pretende conjurar con la medida nacional de limitación genérica del gasto, a través de normas orgánicas del presupuesto.

Las normas acusadas establecen, entre otras, unas determinadas limitaciones sobre el uso que las entidades territoriales le pueden dar a sus recursos de fuente endógena; sin embargo, estas limitaciones son racionales (puesto que se dirigen a atacar la causa directa del problema que se ha identificado, a saber, el desbordamiento del gasto de funcionamiento de los entes territoriales, constituyendo así un medio eficaz para lograr el fin propuesto) y son proporcionadas (por cuanto los porcentajes de limitación del gasto varían de acuerdo con la categoría de la cual se trate, cuando impone los mayores costos sobre las entidades que mayores gastos generan, en términos cuantitativos, y porque se preserva un amplio margen de autonomía para la entidad respectiva en la destinación de los recursos con los que cuenta.

De esta manera, se garantiza al mismo tiempo un interés mayor de la colectividad nacional, sin que exista discriminación -puesto que es una medida general para todas las entidades territoriales-ni perjuicio injustificado para terceros-el cual, en caso de existir, habrá de ventilarse sobre una base casuística, y ante los tribunales u organismos competentes).

Esto quiere decir que las medidas bajo examen, en general, busca combatir un desequilibrio entre los ingresos y los gastos de las entidades territoriales, estipulando que entre estos factores debe existir una relación estable y armónica, en forma tal que los gastos permanentes de las entidades territoriales se puedan financiar con los ingresos corrientes o constantes con los que cuentan, evitando así futuros descalabros; por ello, son constitucionalmente aceptables. 
Así las cosas, a juicio de la Corte, las reglas fiscales se ajustan a la Constitución, a condición de que sean racionales y proporcionales”. (Lozano. I.E 2010).

Ahora bien, vistos los desarrollos doctrinales sobre la globalización y el constitucionalismo frente a la democracia y el Estado social de derecho inicialmente indicados en capítulos que preceden,y destacados los antecedentes legales y jurisprudenciales de la sostenibilidad fiscal en Colombia, se desarrollan los avances jurisprudenciales respecto de los actos legislativos y su sujeción constitucional respecto de la naturaleza y filosofía del Estado social de derecho ya visto en el capítulo inicial de la presente tesis.

Con estos antecedentes, el primero de julio de 2011, el Congreso de la República expidió el Acto Legislativo 03 de 2011sobre la creación del principio constitucional de la Sostenibilidad Fiscal en Colombia, mediante la modificación del artículo 334 de la C.P.

Expresa elActo Legislativo 03 de 2011:

Artículo1 ${ }^{\circ}$. El artículo 334 de la Constitución Política quedará así:

La dirección general de la economía estará a cargo del Estado. Este intervendrá, por mandato de la ley, en la explotación de los recursos naturales, en el uso del suelo, en la producción, distribución, utilización y consumo de los bienes, y en los servicios públicos y privados, para racionalizar la economía con el fin de conseguir en el plano nacional y territorial, en un marco de sostenibilidad fiscal, el mejoramiento de la calidad de vida de 
los habitantes, la distribución equitativa de las oportunidades y los beneficios del desarrollo y la preservación de un ambiente sano. Dicho marco de sostenibilidad fiscal deberá fungir como instrumento para alcanzar de manera progresiva los objetivos del Estado Social de Derecho. En cualquier caso el gasto público social será prioritario.

El Estado, de manera especial, intervendrá para dar pleno empleo a los recursos humanos y asegurar, de manera progresiva, que todas las personas, en particular las de menores ingresos, tengan acceso efectivo al conjunto de los bienes y servicios básicos. También para promover la productividad y competitividad y el desarrollo armónico de las regiones.

La sostenibilidad fiscal debe orientar a las Ramas y Órganos del Poder Público, dentro de sus competencias, en un marco de colaboración armónica.

El Procurador General de la Nación o uno de los Ministros del Gobierno, una vez proferida la sentencia por cualquiera de las máximas corporaciones judiciales, podrán solicitar la apertura de un Incidente de Impacto Fiscal, cuyo trámite será obligatorio. Se oirán las explicaciones de los proponentes sobre las consecuencias de la sentencia en las finanzas públicas, así como el plan concreto para su cumplimiento y se decidirá si procede modular, modificar o diferir los efectos de la misma, con el objeto de evitar alteraciones serias de la sostenibilidad fiscal. En ningún caso se afectará el núcleo esencial de los derechos fundamentales.(Las negrillas son nuestras).

Parágrafo. Al interpretar el presente artículo, bajo ninguna circunstancia, autoridad alguna de naturaleza administrativa, legislativa o judicial, podrá invocar la sostenibilidad fiscal para menoscabar Los derechos fundamentales, restringir su alcance o negar su protección efectiva.(Constitución Política, 2014). 
Así mismo el principio de sostenibilidad fiscal expuesto por dicha norma fue declarado exequible por la Corte Constitucional mediante las Sentencias C-288 y C-332 de 2012, quedando claro que la sostenibilidad fiscal es un instrumento para alcanzar de manera progresiva, las finalidades del Estado Social y Democrático de Derecho, representando ello que la norma sobre 1 sostenibilidad y el incidente de impacto fiscal no implica una sustitución de la Constitución Política.

De esta manera la sostenibilidad y el incidente de impacto fiscalse constituye en una condición para el desarrollo del Estado social y democrático de derecho, cuando se representa según la jurisprudencia enun derecho que contribuye a proteger a todos los demás derechos.

Es de admitir que el artículo 334 de la Constitución Política tocante a los objetivos de la intervención del Estado en la economía, no hace referencia expresa a la sostenibilidad fiscal y que dicha omisión no se cubre con lo dispuesto en el artículo 373 de la misma, que a pesar de exponer la responsabilidad del Banco de la República frente a la necesidad de velar por el poder adquisitivo de la moneda, es insuficiente para establecer una sostenibilidad fiscal general y por ello, el Acto Legislativo 03 de 2011 adquiere mayor relevancia. (Las negrillas son nuestras).

Tal como lo expresa la Sentencia C 1052 de 2012:

Es necesario tener una disposición constitucional expresa que contenga un derecho de todos, que garantice que el Estado tendrá las condiciones, dentro de sus propias 
limitaciones de recursos, de garantizar la prestación y el disfrute de los derechos económicos, sociales y culturales, y por ende una realización sostenible y eficiente del Estado social y democrático de derecho, al tiempo que imponga un deber a las ramas y órganos del poder público de proteger con sus decisiones y actuaciones el mencionado derecho. (p. 20)

Ello apunta a que sin la sostenibilidad y el incidente de impacto fiscal, el Estado Social y Democrático de Derecho, es tan solo una utopía sin bases realizables para alcanzar una verdadera estabilidad macroeconómica y la progresividad de los derechos.

Es importante que el acervo jurídico garantice el respaldo del capital público necesario para adelantar las obras que exige al Gobierno en los proyectos de consolidación de derechos económico y sociales y a la satisfacción de las necesidades básicas de las personas, que representan la cristalización del Estado social y democrático de derecho; que sin la jurisprudencia necesaria, la sostenibilidad fiscal apunta a situaciones negativas que representan la pobreza e inequidad, situaciones de crisis económica que ya se ha abordado en extenso en capítulos que preceden, para fundamentar con solvencia la prevalencia de las diferentes piezas que integran la democracia constitucional. (Las negrillas son nuestras).

De otra parte y dentro de la misma la Sentencia C 1052 de 2012 se puede apreciar:

“...la sostenibilidad fiscal es un requisito para garantizar la prestación de los derechos económicos, sociales y culturales como parte esencial del Estado social de 
derecho y que la misma facilita la progresividad en la atención del conjunto de los derechos, teniendo como marco la disponibilidad de recursos destinados para ello, encontrando como fundamento superior la prevalencia del interés general y atendiendo las prioridades de gasto de acuerdo con las disposiciones constitucionales tal y como lo prevé, por ejemplo, el artículo 350 de la Constitución”. (p. 23)

La disponibilidad de recursos es importante, así como su uso adecuado y dentro de los tiempos correspondientes, lo cual influye en la velocidad con la cual se puede lograr la sostenibilidad fiscal. La prontitud y celeridad para bordar lo proyectos es un asunto clave en la capacidad de lograr un Estado social de derecho sólido y estable para impedir los avances de las políticas neoliberales ya vistas.

Es así que la sostenibilidad fiscal debió enfundarse en la jerarquía constitucional para su preservación y protección, distinguiendo el importante papel que cumple como requisito, para el cumplimiento de los deberes sociales del Estado y la garantía de la efectividad de los derechos a través del crecimiento sostenido de la economía.

Al consagrar que la sostenibilidad fiscal no sólo es un deber del Estado, sino también un derecho de todos, significando que el Legislador está obligado a arrogaren los planes de desarrollo y en las normas presupuestales las normas con el objetivo de proteger, la Sostenibilidad Fiscal de la Nación y a puntualizar los responsables de su cumplimiento, lo que implica el compromiso de las autoridades del Estado en todos sus órdenes de acuerdo con sus 
competencias, en la expedición de normas, reglamentos y de fallos que avalen el fomento del Estado Social de Derecho, bajo criterios de progresividad y sostenibilidad.

Entonces ¿Qué debe entenderse realmente por Sostenibilidad Fiscal en relación con la actividad judicial?

Una respuesta simple, de sentido común, apunta a que exista un equilibrio fiscal, es decir, que los gastos previstos u ordenados para el pago de una sentencia estén previstos o presupuestados. Otra forma de entenderla sería que, aunque no estén previstos o presupuestados tales gastos, puedan solventarse en un futuro.

De otra parte, puede igualmente significar que, sea que existan o puedan existir los recursos, la orden de utilizarlos no suponga que se altere de manera importante la forma como se tenía previsto invertir por los otros órganos del Estado. Implica igualmente que las decisiones judiciales no impiden que se ejecute lo decidido en el Plan Nacional de Desarrollo o en el presupuesto aprobado.

Así mismo, que mediante sentencias no se configure un plan de gobierno alterno, que no se enerven las competencias del Ejecutivo y del Congreso en materia de gasto, es decir, que no exista un cogobierno judicial. (Sentencia C 1052 de 2012, p 73)

Tal como se ha establecido, la Sostenibilidad Fiscal en esta vía sería de vital importancia para la consolidación del Estado Social de Derecho, teniendo que estar correctamente definida para garantizar laestabilidad macroeconómica y la progresividad de los derechos y en esa vía 
podríamos conciliar de mejor manera el enfoque funcionalista en una sociedad orientada hacia el neo conservadurismo y que representa una de las conclusiones al final de nuestro trabajo.

No obstante, existen en la práctica situaciones en las cuales, el derecho social dista de la sostenibilidad fiscal en virtud de incidentes de impacto fiscal, como es el caso expuesto en el año 2013 ante el Consejo de Estado Sala Plena de lo Contencioso Administrativo, ante un incidente promovido por el Procurador General de la Nación en contra de la sentencia proferida por la Sección Tercera del mismo Consejo el primero de noviembre de 2012, mediante la cual se declaraba patrimonialmente responsable al Distrito de Bogotá y a la empresa Prosantana S.A., por los perjuicios ocasionados como consecuencia de la catástrofe ambiental y sanitaria que sobrevino al derrumbe de basuras en el Relleno Sanitario de Doña Juana, ocurrido el 27 de septiembre de 1997.

En primera instancia el Tribunal Administrativo de Cundinamarca - sentencia del 24 de mayo de 2007- declaró responsables tanto al Distrito Capital como a Prosantana S.A., por los perjuicios morales ocasionados a los integrantes del grupo conformado por los demandantes y las personas que entre el 27 de septiembre y el 31 de diciembre de 1997 vivían, laboraban o estudiaban en los barrios correspondientes.

La anterior decisión fue apelada por las partes, y el Consejo de Estado resolvió, en sentencia del 1 de noviembre de 2012: 
TERCERO.- CONDÉNASE al DISTRITO DE BOGOTÁ a pagar a título de indemnización de daño moral y afectación de los derechos constitucionales a la intimidad familiar y a la recreación y libre utilización del tiempo libre, la suma de \$227.440.511.400 a los integrantes del grupo que se hayan constituido como parte en el proceso y los que lo hagan después, en los términos señalados en la parte motiva. La suma de dinero constitutiva de esta condena se deberá pagar al Fondo para la protección de los derechos e intereses colectivos, administrado en los términos de ley, por el Defensor del Pueblo.

Ante esta decisión el 18 de enero de 2013, el Alcalde Mayor de Bogotá, Gustavo Petro Urrego, solicitó a la Procuraduría General de la Nación que promoviera la apertura de un incidente de impacto fiscal, teniendo como fundamento que la condena afectaba la sostenibilidad fiscal del Distrito, por la cuantía y la disposición para cancelarla suma en cuestión.

El Procurador General de la Nación, mediante escrito del 25 de febrero de 2013, requirió la apertura del incidente considerando que en efecto la providencia afectaba de manera sería el funcionamiento del Distrito de Bogotá, para lo cual presentó los siguientes argumentos:

i) un esfuerzo adicional significativo para conseguir recursos que no se tenían previstos, ni en la estrategia financiera del plan de desarrollo ni en el marco fiscal de mediano plazo 2013-2023, presentado al Concejo Distrital conjuntamente con el Proyecto del Presupuesto 2013; ii) la disminución de las fuentes de ingreso del presupuesto distrital, por concepto de rendimientos financieros; y iii) plantear un recorte en las inversiones programadas en el Plan de Desarrollo "Bogotá Humana", generando consecuencias en la atención de la población vulnerable. (Consejo de Estado, 213, p. 4). 
Luego de la exposición de los argumentos el Consejo de Estado decidió admitir la solicitud de impacto fiscal, tras reconocer que no existen los recursos para cancelar la indemnización que se le impuso al Distrito de Bogotá y pese a que el mismo Consejo de Estado había impuesto la resolución condenatoria en virtud del derecho que asistía a las víctimas y afectados de la emergencia.

Frente a esta situación cabe preguntarse entonces: ¿Cuál puede ser el mecanismo jurídico para que el equilibrio macroeconómico no esté en contraposición de las decisiones en derecho que promueven el Estado Social de Derecho? ¿Cuál sería la importancia jurídica si se tiene mayor consonancia para un incidente de impacto fiscal que la propia afectación a los derechos constitucionales de los diversos grupos?, y lo que es más importante ¿qué pasaría entonces con el derecho a ser resarcidos económicamente los afectados?

Por razones de trascendencia económicala condena por \$227.440.511.400 es virtualmente impagable porque afecta el presupuesto del Distrito, lo que representa que muy seguramente los afectados no obtendrán jamás la indemnización que les corresponde en derecho.

Esta situación, refleja en tan solo un ejemplo, de lo que podría ocurrir en el territorio nacional respecto a diversos casos que exigen la reparación jurídica del Estado y que a pesar de lograrla en las instancias judiciales, en la práctica se convierten en sentencias estériles que no poseen aplicación y que a la postre afectan el derecho de comunidades. 
Consejo de Estado, Sala Plena de lo Contencioso Administrativo. (28 de mayo de2013) Consejero ponente: Enrique Gil Botero. Incidente de Impacto Fiscal.

De otra parte y para culminar el análisis jurisprudencial que antecede, la Corte Constitucional al examinar esta regla fiscal, advirtió en sentencia C-579 de 2001 que tales reglas fiscales, a juicio de la Corte, se ajustan a la Constitución por las razones ya expuestas en sentencias ya citadas.

Finalmente, las leyes 819 de 2003 por la cual se dictan normas orgánicas en materia de presupuesto, responsabilidad y transparencia fiscal, se obliga al Gobierno nacional a presentar un Marco Fiscal de Mediano plazo, donde la Ley 1448 o Ley de Victimas contiene principios de sostenibilidad mediante la creación de documentos CONPES con el fin de fortalecer el Fondo de Reparaciones previsto en la Ley 975 de 2005, para asegurar el principio de sostenibilidad fiscal.

A su vez, las leyes 1454 de 2011 y 1473 de 2011, dictaron normas orgánicas sobre ordenamiento territorial y ordenaron la sostenibilidad fiscal en esos entes del Estado con las implicaciones o impactos negativos en el proceso de descentralización fiscal.

En este orden de ideas, el Gobierno nacional, a través de leyes ordinarias y orgánicas ha encaminado reglas para lograr sanear las finanzas públicas, obligaciones de sostenibilidad en el presupuesto nacional para racionalizar el gasto público y en suma, para lograr el desarrollo del principio de sostenibilidad fiscal regido por los parámetros de coherencia y proporcionalidad en el gasto público. 
Todo lo expuesto representa un análisis funcional de la jurisprudencia colombiana en torno a la procedencia de la figura de la Sostenibilidad a través del incidente de Impacto Fiscal que es visto como importante para procurar las finanzas públicas, pero nada se afirma respecto del impacto en la garantía de derechos en su afectación o limitación. 


\section{CAPÍTULO 5}

\section{La Sostenibilidad Fiscal en la Constitución Política de Colombia y sus repercusiones en los fallos de responsabilidad patrimonial del Estado.}

El sustento conceptual expuesto en el capítulo anterior y el caso de la providencia condenatoria al Distrito de Bogotá,demuestran que existe una tensión entre el constitucionalismo y la democracia o la expresión del Estado social y para el caso en particular en análisis, generauna controversia desde diferentes sectores acerca de los beneficios del principio de la sostenibilidad fiscal, para garantizar los recursos que ya poseen destinación presupuestal dentro de los proyectos gubernamentales que suponen beneficios sociales, económicos y comerciales para los colombianos, a contracara de aquellos que afirman que dicho principio se constituye en un parangón jurídico mediante el cual el Estado puede deferir en el tiempo, obligaciones y responsabilidades en detrimento de los derechos humanos, sociales y ciudadanos y que se ha tratado en el desarrollo conceptual que antecede.

En este sentido y por lo visto, existen quienes opiniones de quienes dan su aprobación al principio de sostenibilidad fiscal:

La inclusión del concepto de sostenibilidad fiscal es un criterio que busca la estabilidad macroeconómica, teniendo como marco la disponibilidad de recursos y la prevalencia del interés general de la población, estos principios esenciales de la Constitución Política, no están siendo eliminados ni limitados por el Acto Legislativo, por el contrario, en la medida 
que se logre cumplir con el adecuado manejo de la economía, esta situación promoverá mejores perspectivas para el crecimiento económico en el mediano plazo favoreciendo así el mayor acceso de los ciudadanos a los bienes y servicios a los que tienen derecho.

Es cierto que los jueces fallan conforme a la ley. Lo más probable es que en la enorme mayoría de casos, las órdenes de los jueces sean ajustadas a derecho de conformidad con el artículo 230 constitucional. Pero lamentablemente también es cierto, que el Estado colombiano no tiene suficientes recursos para cumplir con las exigencias de quienes pueden materializar sus derechos a través de mecanismos jurídicos como la acción de tutela, y las demandas de restablecimiento ante la jurisdicción contencioso-administrativa, y al mismo tiempo cumplir con el mandato constitucional de llevar la dignidad humana a todos los ciudadanos colombianos. (Sentencia C-J32 de 2011, p. 62)

Como aquellos que dan su voto de desaprobación:

La reforma constitucional está en contravía de los principios del Estado Social de Derecho, toda vez que al darle rango superior al principio de sostenibilidad fiscal está centrando la actividad de aquél en un ámbito exclusivamente económico, razón por la cual limita la autonomía administrativa y la independencia financiera, obligando a las entidades estatales a adoptar decisiones en torno a los derechos fundamentales en función del presupuesto. Lo anterior constituye una sustitución de la Constitución.

...Mientras que la Carta Política de 1991 consagró el postulado del Estado Social de Derecho (artículo 1 Superior), el Acto Legislativo 3 de 2011 lo suprime de un tajo al condicionar toda la actividad de planeación y presupuesto nacional a la "regla fiscal" ya 
que la "sostenibilidad fiscal" debe regir a las ramas del poder público (Legislativa, Ejecutiva y Judicial) y a los Órganos del Estado (los órganos de control: Contraloría General de la República y el Ministerio Público, la Organización Electoral y los otros órganos del Estado: Banco de la República, Comisión Nacional de Televisión, universidades públicas y Comisión Nacional del Estado Civil).

...se presenta una clara oposición entre el artículo 2 Superior y el Acto Legislativo 3 de 2011, ya que esta norma establece en forma perentoria que todas las acciones estatales deben estar dirigidas al servicio de la comunidad y debe promover la prosperidad general, mientras que con la reforma del Acto Legislativo 3/2011, lo que debe primar es la sostenibilidad fiscal. (Sentencia C-J32 de 2011, p. 8)

Es así que en desarrollo del artículo 334 de la Constitución Política se han dictado disposiciones para su aplicación mediante la Ley 358 de 1997, "Por la cual se reglamenta el artículo 364 de la Constitución y se dictan otras disposiciones en materia de endeudamiento", la cual estableció límites de endeudamiento para las Entidades Territoriales, con el fin de que no excedan su capacidad de pago.

De igual manera y como ya se enuncio, existe la Ley 617 de 2000, conocida como "Ley de responsabilidad fiscal territorial", la cual se tramitó con miras a la racionalización de los recursos fiscos departamentales, municipales y distritales, mediante la clasificación de las entidades territoriales en categorías presupuéstales y el establecimiento de topes máximos para sus gastos de funcionamiento. 
A consideración de la Corte Constitucional la sostenibilidad fiscal está dentro de los parámetros constitucionales, tal como lo expone en la Sentencia C- 579 de 2001:

Tales reglas fiscales, a juicio de la Corte, se ajustan a la Constitución, por las siguientes razones:

En términos generales, y salvo las excepciones que abajo se precisan, puede afirmarse que las medidas adoptadas por el proyecto cumplen con los requisitos arriba trazados para ser declaradas exequibles. Ello, por dos motivos:

- Existe una grave crisis macroeconómica, que potencialmente se verá catalizada por la situación deficitaria de las entidades territoriales, cuya estructura de gastos es una de las fuentes directas de la situación; esta situación, que rebasa la esfera propia de los intereses exclusivos de las entidades territoriales, es la que se pretende conjurar con la medida nacional de limitación genérica del gasto, a través de normas orgánicas del presupuesto.

- Las normas acusadas establecen, entre oirás, unas determinadas limitaciones sobre el uso que las entidades territoriales le pueden dar a sus recursos de fuente endógena; sin embargo, estas limitaciones son racionales (puesto que se dirigen a atacar la causa directa del problema que se ha identificado, a saber, el desbordamiento del gasto de funcionamiento de los entes territoriales, constituyendo así un medio eficaz para lograr el fin propuesto) y son proporcionadas (por cuanto los porcentajes de limitación del gasto varían de acuerdo con la categoría de la cual se trate, imponiendo los mayores costos sobre las entidades que mayores gastos generan, en términos cuantitativos, y porque se preserva un amplio margen de autonomía parala entidad respectiva en la destinación de los recursos 
con los que cuenta, garantizando al mismo tiempo un interés mayor de la colectividad nacional, sin que exista discriminación -puesto que es una medida general para todas las entidades territoriales- ni perjuicio injustificado para terceros -el cual, en caso de existir, habrá de ventilarse sobre una base casuística, y ante los tribunales u organismos competentes). Esto quiere decir que las medidas bajo examen, en general, busca combatir un desequilibrio entre los ingresos y los gastos de las entidades territoriales, estipulando que entre éstos factores debe existir una relación estable y armónica, en forma tal que los gastos permanentes de las entidades territoriales se puedan financiar con los ingresos corrientes o constantes con los que cuentan, evitando así futuros descalabros; por ello, son constitucionalmente aceptables.

Posteriormente es aprobada laLey 819 de 2003,

"Por la cual se dictan normas orgánicas en materia de presupuesto, responsabilidad y transparencia fiscal y se dictan otras disposiciones", la cual obliga al Gobierno Nacional a presentar ante el Congreso de la República un Marco Fiscal de Mediano Plazo el cual contendrá, como mínimo (i) un Plan Financiero; (ii) un programa macroeconómico plurianual; (iii) las metas de superávit primario, así como el nivel de deuda pública y un análisis de su sostenibilidad; (iv) un informe de resultados macroeconómicos y fiscales de la vigencia fiscal anterior; (v) una evaluación de las principales actividades cuasi fiscales realizadas por el sector público; (vi) una estimación del costo fiscal de las exenciones, deducciones o descuentos tributarios existentes; (vii) el costo fiscal de las leyes sancionadas en la vigencia fiscal anterior; y (viii) una relación de los pasivos contingentes que pudieran afectar la situación financiera de la Nación. 
Incluso la "Ley de víctimas" (Ley 1448 de 2011) se refiere al tema de la sostenibilidad fiscal para efectos de cumplir con las medidas de ayuda humanitaria, atención, asistencia y reparación de víctimas.

Por su parte la Sentencia C-288 de 2012 indica en ocasión del "principio" o criterio de sostenibilidad fiscal que tan solo tiene un carácter instrumental

Tanto del análisis conceptual como del estudio histórico del Acto Legislativo demandado, se infiere con claridad que el criterio ordenador no es un fin constitucional en sí mismo considerado, sino apenas un medio para la consecución de los objetivos esenciales del Estado Social y Democrático de Derecho y por esta razón se ha hecho mención a un mero instrumento que ha consolidado en el tiempo la vigencia de un Estado fiscal.

Más recientemente se dicta la Ley 1695 del 17 de diciembre del 2013, esta reglamentación es accesoria a la Sentencia C-1052 de 2012, normas que han sido objeto de objeciones y demandas por inconstitucionalidad, como las presentadas por el representante del Polo Democrático Alternativo, Germán Navas Talero y el constitucionalista Rodolfo Arango Rivadeneira, quienes consideraban en su demanda de enero del 2014 que los artículos 1, 2, 3, 4, 5, 6, 8, 9, 11, 12, 13 y 14 de la Ley 1695 de 2013, son contrarios a disposiciones contempladas en la Constitución en sus artículos1, 2, 5, 13, 29, 86, 93, 113, 152 literal a), 228, 230 y 334.

Lanorma demandada se sustentaba en cargos diferentes: Ley estatutaria, menoscabo jurídico, Espada de Damocles, Derechos humanos, Subjetividad procesal y Desigualdad procesal. 
Así mismo, el historiador y abogadoAndrés de Zubiría Samper ha señalado la inconstitucional de la Ley 1695 de 2013. Los cargos alegados son:

(i) Vulneración del concepto de Estado Social de Derecho, previsto en el artículo $1^{\circ}$ de la Constitución; (ii) violación del fundamento de la acción de tutela, regulada por el artículo 86 y 241 de la C.P.; (iii) vulneración de la autonomía de las entidades territoriales, consagrada en el artículo 287 C.P. y (iv) violación del "principio" de sostenibilidad físcal de que trata el artículo 334 C.P. (p. 5).

En respuesta a dicha demanda la Procuraduría General de la Nación en marzo del 2014 se declaró inhibida para pronunciarse al respecto y en igual medida lo hizo la Corte Constitucional mediante la Sentencia C-584 del 2014.

Tomando como referencia estas posiciones en favor y en contra del principio de la sostenibilidad fiscal, así como el caso citado en el capítulo antecedente respecto a la condena al Distrito de Bogotá que en la práctica es improcedente por razones de equilibrio macroeconómico, podemos citar a Gómez, Mosquera \& Ochoa (2012) cuando afirman:

La primera incidencia negativa que surge de la inclusión del Principio de sostenibilidad fiscal en la constitución política de Colombia, es una evidente infracción al Principio de separación de los poderes y de las Ramas del Poder Público, pues resulta claro que en la práctica estaríamos frente a una intervención 
de la rama ejecutiva, en las otras ramas y órganos del poder público, con un mayor énfasis en la rama judicial.

Lo que se busca con la regla fiscal principalmente es que una vez proferidas las sentencias por cualquiera de las máximas corporaciones judiciales, se module, modifique o difiera los efectos de las mismas. (p. 14).

Estos tres verbos,"modular, diferir, modificar," se encuentran expresamente señalados en el artículo 334 del Acto Legislativo 03 de 2011, y mientras los dos primeros brindan seguridad a las relaciones jurídicas y al ordenamiento jurídico el tercero apunta en contravía de ello, ya que la modificación implica el cambio, transformación o la concepción de un nuevo sentido de lo establecido, que en el campo jurídico constituye un hecho antijurídico, más aún cuando se trata de una cosa juzgada, afectando las decisiones de los jueces de la república emanadas de un examen crítico de las pruebas y los razonamientos legales, de equidad o doctrinarios.

Según las normas que establece la jurisprudencia colombiana cuando existen fallos conformes a la ley su cumplimiento es obligatorio y debe dársele trámite dentro de los términos correspondientes, en caso contrario, se estaría lesionando la actividad procesal y los derechos de aquellos beneficiados con los fallos.

Es anticonstitucional e ilógico desde cualquier punto de vista que una decisión legal proferida por una autoridad judicial sea modificada, existiendo una grave violación al Principio de separación de poderes. 
Resulta evidente que lo que se busca con una determinada sentencia judicial o de tutela, en últimas, es el reconocimiento de unos perjuicios o de un derecho, los cuales son reparados o reconocidos integralmente, que la mayoría de veces se materializan a través de una indemnización, de tal modo que la sentencia en sí misma no tendría sentido práctico si estos perjuicios y derechos no fueran reparados y reconocidos integralmente y llevados a la práctica. Luego, este reconocimiento de perjuicios o derechos es el efecto inmediato de la sentencia y funge como situación de fondo en la parte motiva y resolutiva de la misma, que de ser modificada, desconocería el principio constitucional de la cosa juzgada y por ende los derechos que en el fallo se reconocen. (Gómez, Mosquera \& Ochoa, 2012, p. 17)

Es contrario a los postulados del Estado Social y Democrático de Derecho que derechos reconocidos mediante un proceso judicial deban ser nuevamente reconocidos y concedidos. Para quienes justifican la sostenibilidad fiscal el parágrafo del artículo 1 de Acto Legislativo 03 de 2011 es el principal fundamento que esgrimen cuando reza:

Al interpretar el presente artículo, bajo ninguna circunstancia, autoridad alguna de naturaleza administrativa, legislativa o judicial, podrá invocar la sostenibilidad fiscal para menoscabar los derechos fundamentales, restringir su alcance o negar su protección efectiva.

Es decir que la sostenibilidad fiscal en ningún caso puede ser una herramienta para afectar los derechos fundamentales, más aun los que se han reconocido mediante la actividad procesal y determinados por un juez en cumplimiento del artículo 230 constitucional. 
Ahora pues, tomemos el ejemplo de los derechos de las víctimas del conflicto armado colombiano a quienes les asisten el derecho a la reparación de la víctima, la cual según la Sentencia T-458 de 2010 se consigue mediante: a) Medidas de restitución; b) Medidas de indemnización; y c) Medidas de readaptación. Al analizar el choque entre la sostenibilidad fiscal y la garantía del Estado Social de Derecho su ejercicio evidencia las fallas y los vacíos que posee el sistema.

Gómez, Mosquera \& Ochoa (2012) lo sintetizan de la siguiente manera:

Si observamos estos aspectos y los multiplicamos por la cantidad de víctimas que existen en Colombia, la conclusión inmediata es que las sentencias por cuenta de estas reparaciones son de proporciones colosales, que evidentemente causarían un gran impacto fiscal. Pero en aplicación del principio de sostenibilidad fiscal nos podríamos preguntar ¿cuáles de los tres aspectos mencionados se modificarían, modularían o diferirían?, teniendo en cuenta que los tres generan un alto costo. Sobre este punto, es claro que no habría una reparación integral y se terminaría re victimizando a la víctima con el incidente de impacto fiscal. Lo anterior nos lleva a concluir que toda esta normativídad en torno a este caso particular de las víctimas se quedarán solo en el papel que soporta las presiones internacionales, pero a nivel interno no se protegen estos derechos, por el contrario, lo que se busca es blindar al Estado de estos fallos que en la mayoría de los casos son producto de su mismo actuar negligente. (p. 19). 
Según esta perspectiva el Principio de Sostenibilidad Fiscal afecta el reconocimiento de los derechos humanos y derechos fundamentales de las personas, pues al modificarse las decisiones de un proceso jurídico, se multiplican las acciones de tutela, en virtud de lograr nuevamente lo ya alcanzado en materia de derechos mediante fallos decisorios y compelidos como cosa juzgada.

En la práctica se abrirá una nueva batalla entre la Sostenibilidad Fiscal y la Acción de Tutela, puesto que la sostenibilidad fiscal también se aplica a los fallos de tutela, pero ¿qué sucederá cuando un ciudadano no conforme con lo resuelto en el incidente de impacto fiscal, formule una tutela contra este incidente por vulnerar sus derechos fundamentales?

En este entendido ¿no procedería la tutela contra este incidente, toda vez que ya se modulo o modifico el fallo?, o, por el contrario, ¿se concedería la tutela y primaria la protección de los derechos fundamentales?; pero en este último supuesto, ¿volvería entonces a iniciarse incidente de impacto fiscal?

Lo anterior es una duda que nos asalta y que solo podrá ser resuelta en la práctica. (Gómez, Mosquera \& Ochoa, 2012, p. 20).

Para los defensores del constitucionalismo, el papel de los jueces constitucionales no conlleva un peligro para la democracia. El control constitucional es la mejor garantía de los derechos fundamentales y esas condiciones hacen posible el reto de construcción de la democracia como tema ampliamente debatido en el marco del desarrollo conceptual de la tesis que apostaría por la omnipotencia judicial antes que a la omnipotencia legislativa por las 
características propias de nuestro modelo político atravesado por la corrupción administrativa como una amenaza prevalente para la existencia y desarrollo del Estado social de derecho que debe velar por las decisiones de amparo de los derechos fundamentales, más que a necesidades sociales en manos de la clase política que sobrevive mediante reformas para la perpetuidad del poder político y económico.

Por ahora, “...es necesario insistir en que la soberanía (aunque sea limitada) reside en los ciudadanos $\mathrm{y}$, por lo tanto, que el ultimo poder de decisión sobre las cuestiones fundamentales debe seguir en sus manos...me parece que el poder de los jueces constitucionales puede y debe limitarse. De lo contrario los garantes del gobierno de las leyes pueden convertirse en los hombres que gobiernan”. (Salazar, 2006).

Debe existir una dialéctica entre la rama legislativa, la rama judicial y el poder ciudadano que se ha destacado como excluido en la participación real en la defensa de sus derechos, para encontrar puntos de equilibrio frente al poder económico ampliamente analizado y que se expresa como una amenaza al Estado social de derecho como exigencia de democracia con prevalencia del gobierno de las leyes.

En este aspecto, ya Kelsen había evidenciado esta dificultad cuando los principios constitucionalesquedan en poder de los intérpretes que acuden a creación de justicia inter partes de una parte del derecho, pero que no se expresa en la totalidad la justicia social como elemento importante de la democracia concebida en la prevalencia del Estado social, nunca del Estado fiscal. 
Finalmente, es oportuno acotar ante este escenario que la Sostenibilidad Fiscal plantea una discordancia entre el sentido económico y los derechos fundamentales, estando esta última en función de la primera, donde primael modelo económico por sobre la integralidad del Estado Social de Derecho que se ha procurado defender desde el punto de vista doctrinal en la presente tesis, como respuesta a las preguntas e inquietudes planteadas como metodología propuesta, donde la Sostenibilidad Fiscal y el Incidente de Impacto Fiscal es a la postre una herramienta o instrumento de coordinación entre las autoridades pública que lleva implícito el respeto de las ramas del poder público. 


\section{CAPÍTULO 6}

\section{Las Políticas Económicas y el Incidente de Impacto Fiscal en el Estado Social de Derecho.}

De conformidad con los argumentos antepuestos respecto a la Sostenibilidad Fiscal respecto de la estabilidad macroeconómica y la progresividad o relatividad de los derechos que garantiza el Estado Social y Democrático de Derecho, el Incidente de Impacto Fiscal representa un criterio desarrollado y reglado por el Congreso de la República para reformar la Constitución Política a través de un acto legislativo, que podría generar serias contradicciones entre el funcionamiento del aparato estatal y las obligaciones del mismo y donde están de por medio los enfoques teóricos sobre la materia con los cuales se dio inicio a la presente tesis, de acuerdo con la doctrina y la jurisprudencia en la materia que nos lleve a conclusiones sobre la vigencia del Estado social.

Independientemente de estos análisis, reflexiones y casos en la práctica administrativa decidida por la labor legislativa y judicial, la administración entra a garantizar una justicia social sui generis, por cuanto la Sostenibilidad Fiscal podría condicionar el bienestar general y limitar los derechos reconocidos en el marco de procedimientos judiciales, que podría llevar de forma implícita el desconocimiento de las decisiones adoptadas por un juez que está protegida por el principio de la cosa juzgada, que como ya se advirtió no es procedente, pues el incidente solo procedería sobre los proyectos de sentencias y nunca sobre las decisiones ejecutoriadas y tampoco se estaría vulnerando la autonomía de las ramas del poder público. 
El Impacto Fiscal en los términos establecidos en el Acto Legislativo 03 de 2011, modificatorio del artículo 334 de la Constitución,representa la inclusión de una norma nueva que no pone límites al reconocimiento de derechos, sino que también autoriza una transformación de una sentencia proferida por cualquiera de las máximas corporaciones judiciales antes de ser ejecutoriada (Corte Constitucional, Corte Suprema de Justicia, Consejo de Estado y Consejo Superior de la Judicatura), teniendo esta modulación o modificación carácter obligatorio, con el objeto de evitar alteraciones de la sostenibilidad fiscal,que contradice las decisiones avaladas en un proceso jurídico plenamente válido.

En el proceso que condujo al fallo de exequibilidad del Acto Legislativo 03 de 2011 expuesto en la Sentencia C-1052 del 2012, se puede observar respecto a la intervención del Ministerio de Justicia y del Derecho:

Con la reforma propuesta, Colombia creará un modelo institucional original, en donde se concibe la colaboración obligatoria de todos los órganos del poder público en alcanzar la Sostenibilidad Fiscal, como instrumento para realizar, de manera sostenible, el conjunto de derechos propios de un Estado Social de Derecho. (p. 6)

Ello apunta a que la prioridad de todos los órganos del poder público es la sostenibilidad fiscal, quedando la realización del Estado Social de Derecho no como un derecho constitucional libre de apremio presupuestal de carácter amplio y sin exclusiones, sino como un proyecto que se determina por el monto de los recursos económicos que el Estado disponga y vea en riesgo la sostenibilidad fiscal. 
Es decir que los derechos que todos los colombianos poseemos gracias la carta magna solo no se pueden garantizar y ejercer libremente por la rama judicial, sino en la medida que el Estado tenga los recursos económicos para reconocerlos, de manera anticipada y antes de cosa juzgada.

El Estado Social y Democrático de Derecho pasaría entonces de ser un principio jurídico general a un concepto medido en función de la labor impositiva del Estado. Bajo esta perspectiva el Estado Social de Derecho de los colombianos, se amplía o se reduce según las variaciones que posea el presupuesto nacional o de la cantidad de impuestos que el gobierno haya logrado recaudar, pudiendo dar paso al concepto y prioridad del denominado Estado Fiscal o bien a la coexistencia de las dos visiones de Estado.

Una cosa son las finanzas públicas y otra los derechos fundamentales adquiridos constitucionalmente, por lo que un incidente de impacto fiscal no podría estar por encima de los principios del Estado Social y Democrático de Derecho y así lo ha afirmado de manera reiterada la Corte Constitucional, que se centran en reconocer los mismos beneficios para todos los ciudadanos, en favor de la equidad y la justicia, pero condicionado a realidades macroeconómicas y de consumo capitalista, acorde con las lógicas del mercado neoliberal y de extracción minera ya estudiado.

Por ello tampoco la modificación de laudos en derecho representa una contribución a la armonía social, si es el propio gobierno quien limita los derechos fundamentales hasta donde llegue el gasto público. 
Dentro de la Sentencia C-1052 del 2012 la demandante resalta la irregularidad procesal de haber introducido el concepto del impacto fiscal tan solo en el sexto debate de los ocho reglamentarios en el Congreso de la República, cambiando totalmente su razón y discreción:

El criterio de sostenibilidad fiscal se limitaba a un criterio orientativo de la actividad de los funcionarios, el cual debía ser considerado por las autoridades de manera autónoma en el ejercicio de sus funciones y en la adopción de las decisiones que les correspondiera adoptar. No obstante, luego de la introducción del inciso $4^{\circ}$ demandado, el alcance del concepto varió de manera sustancial porque comporta la posibilidad de que las autoridades administrativas o el Procurador General intervengan ante los jueces de la República para que modifiquen las decisiones que han adoptado autónomamente. (p. 9) (Sobre este aspecto ya existe suficiente claridad doctrinal y jurisprudencial).

Mediante esta nueva figura las acciones constitucionales de protección de los derechos fundamentales quedarían supeditadas a control abstracto administrativo condicionadas por las finanzas públicas. Como bien señala la demandante "Es inevitable que los derechos fundamentales de las personas sufran una afectación considerable por el solo hecho de la introducción de un incidente cuya consideración y resolución son obligatorios para el juez constitucional" (Sentencia C-1052 del 2012, p. 10).

Frente a la demanda examinada mediante la Sentencia C-1052 del 2012 la representación del gobierno en cabeza de los Ministerios de Justicia y del Derecho, de Hacienda y Crédito Público y el Departamento Nacional de Planeación, consideraron que la norma acusada sí se 
ajustaba a la Carta, mientras que la Defensoría del Pueblo, la Academia Colombiana de Jurisprudencia y la Universidad del Rosario, estimaron que la Corte debía declarara la inexequibilidad del inciso del artículo 1 del Acto Legislativo 03 de 2011demandado, en razón a la irregularidad en el proceso de aprobación.

\section{La Corte Constitucional decidió la exequibilidad teniendo como base el principio de identidad flexible, quedando en firme la aplicación del Incidente de Impacto Fiscal en Colombia.}

Sobre esta base es que en el año 2013 el Procurador General de la Nación promueve la declaración del Incidente de Impacto Fiscal en contra de una sentencia proferida en noviembre de 2012, mediante la cual se declaraba patrimonialmente responsable al Distrito de Bogotá y a la empresa Prosantana S.A., por los perjuicios ocasionados por la catástrofe ambiental y sanitaria que generó el derrumbe de basuras en el Relleno Sanitario de Doña Juana en el año de 1997. La sentencia proferida por el Tribunal Administrativo de Cundinamarca de manera explícita hizo responsable al Distrito de Bogotá y a lo condenó a indemnizar a los afectados con la suma de \$227.440.511.400, no obstante, como ya se ha expuesto, la decisión fue modificada en virtud del Incidente de Impacto Fiscal que considera virtualmente impagable esa cifra porque afecta el presupuesto del Distrito.

Es decir que una decisión sobre derecho, dictada por un juez de la República en cumplimiento de las normas procesales correspondientes, garantiza los derechos fundamentales de los colombianos y reconoce una compensación; en la práctica, puede ser objeto de 
modificación, que en este caso significa negar un fallo en firme a solicitud del Procurador General de la Nación, debido a que el Estado no tiene dentro de sus cuentas el pago de indemnizaciones de este tipo.

A todas luces cuando el artículo 334 del Acto Legislativo 03 de 2011 los verbos, "modular, diferir, modificar," abrió con este último una puerta para que una decisión jurídica pudiera "modificarse", o más bien, transformarse sustancialmente llegando incluso a desconocerse la esencia del fallo en virtud de los derechos fundamentales.

En la solicitud de apertura del incidente de impacto fiscal analizada por el Consejo de Estado (2013), incluso admite que la decisión tomada en la demanda contra Distrito de Bogotá es inevitablemente objeto de cambio:

Sin embargo, para no engañarse incautamente, se sabe que es imposible no alterar la decisión inicial, aunque sea de manera parcial y levemente, cuando la Alta Corte accede a modular, modificar o diferir los efectos de la providencia, pues si se condenó y ordenó cumplir de una manera, decir luego que se cumplirá de otra o en un tiempo diferente al que señaló la sentencia, supone, necesariamente, una variación de la orden impartida. En realidad, después de dictarse sentencia, su modulación, modificación o diferimiento, así sea sólo de los efectos de la condena, necesariamente cambia ese aspecto de la misma, y el juez debe actuar con prudencia excesiva y máxima sensatez, para no intervenir más allá de la limitada posibilidad que adquiere, a partir del art. 334 de la C.P., de alterar parte de la decisión inicial, y no poner en peligro la cosa juzgada, cuyo valor jurídico no puede estar en riesgo, hasta desnaturalizarla y quedar a merced de un principio económico, que 
también debe ajustarse a la necesidad que existe de concretar la idea de justicia material y particular, representada en el cumplimiento de una condena, producto de años de disputa entre las partes ante la rama judicial. (Consejo de Estado, 2013, p. 22)

Así pues, la cosa juzgada es objeto de modificación a discreción del juez que no debe tener como prioridad el principio económico como límite para el reconocimiento de los derechos fundamentales, sin embargo mediante la figura del Incidente de Impacto Fiscal apoyada en argumentos de presupuesto en la práctica se puede cambiar un falló totalmente y negar la indemnización que corresponde por derecho a las víctimas del desastre ambiental generado por el Distrito de Bogotá y a la empresa Prosantana S.A.

La solicitud de apertura del incidente de impacto fiscal también advierte:

En otras palabras, le corresponderá a las Altas Cortes examinar con el máximo cuidado que los derechos no queden condicionados injustamente y hasta odiosamente a un criterio fiscal eficientista, ajeno a la justicia del caso concreto, porque de no moderarse y exigirse que esté a disposición de la garantía de la justicia y de los derechos, puede tiranizarlos y someterlos a la lógica económica, sin consideración a la justicia individual y colectiva, en la que también se fundan la sociedad y el derecho. (Consejo de Estado, 2013, p. 22)

Por estas conclusiones jurisprudenciales, cabría preguntarse lo siguiente:

¿Acaso con la decisión de no indemnizar a las víctimas del desastre no se está contraviniendo la garantía de justicia que por derecho les corresponde y que se les había 
reconocido mediante un fallo en derecho? ¿Los perjuicios materiales y de otra índole que sufrieron los demandantes por acción del Distrito de Bogotá y a la empresa Prosantana S.A., entonces deben olvidarse y cada uno de ellos resignarse a asumir sus pérdidas? ¿Es esto justicia en función de los derechos o del criterio fiscal?

Para finales del año 2013 se da la reglamentación del Incidente de Impacto Fiscal mediante la Ley 1695 del 2013, por medio de la cual se desarrolla el artículo 334 de la Constitución política y se dictan otras disposiciones, siendo demandada por inconstitucionalidad pocos meses después por el doctorAndrés de Zubiría Samper, quien en su exposición de motivos cita la Sentencia C-250 de 2012 de la siguiente manera:

“[e]l incidente de impacto fiscal viola flagrantemente el Principio de la seguridad jurídica, ya que si el Incidente prospera se podría 'modular, modificar o diferir los efectos de la misma’ providencia, y a pesar de que ésta última hace tránsito a cosa juzgada (es definitiva e inmodificable), se estaría atentando contra la esencia misma de la cosa juzgada y, por ende, de la seguridad jurídica", la cual entiende 'consagrada' “en el preámbulo y en el texto de la Constitución Política". Por esta misma razón, concluye que "parecería que entra a primar en Colombia[,] a partir de la vigencia de la citada Ley 1695/2013, no [...] la garantía de los derechos sociales económicos, sociales y culturales, como ordena el Capítulo 2 del Título II, sino el componente económico y, específicamente, el impacto fiscal”. (De Zubiría, 2014, p. 4)

Es decir, que al quedar a cargo de las Altas Cortes modificar las sentencias según su criterio, se podría violar la Constitución y en consecuencia afectar los derechos de los 
colombianos, cuando prima entonces la Sostenibilidad Fiscal, en detrimento de los derechos fundamentales, los derechos humanos y los derechos colectivos, además de atentar contra la autonomía que gozan las divisiones político-administrativas a nivel territorial, cuando autoriza al Procurador General de la Nación o a los Ministros de Hacienda, a interferir en la administración de un municipio o departamento al solicitar la apertura del Incidente de Impacto Fiscal.

La Ley 1695 del 2013 afirma fortalecer el Estado Social de Derecho mediante el mismo principio de Sostenibilidad Fiscal, gracias a que mediante la figura del incidente de impacto fiscal se pueda modular, modificar o diferir un fallo judicial, lo que en ejercicio del derecho representa violar la norma de la cosa juzgada y en la práctica abrir una brecha para la realización del Estado Social y Democrático de Derecho al incidir en el reconocimiento de derechos. Al respecto la Sentencia 1052 de 2001 afirma que:

"podría hacer negatorio algún derecho, en especial, las sentencias de revisión de tutela proferidas por la Corte Constitucional, que son precisamente las que protegen los derechos constitucionales fundamentales" ... "al iniciarse un Incidente de impacto fiscal contra una sentencia de una alta corporación judicial [...] se atenta contra la independencia judicial”, como expresión de la separación de poderes. (p. 5)

De tal manera que el Incidente de Impacto Fiscal que se invoque sobre argumentos económicos para garantizar el Estado Social de Derecho, podría afectar en la realidad derechos que son prioridades en su expresión de bienestar en los ciudadanos, convirtiendo al Incidente de Impacto Fiscalen excusa para no acatar los fallos que protegen los derechos de la población, 
evitando a su vez sentencias que involucran recursos públicos para el gasto social como prioritario, podrían ser a su vez destinados a otras prioridades de los gobiernos para afianzar la gobernabilidad política.

En esta materia, no existe un suficiente desarrollo por parte de la doctrina. Esta razón, nos presenta a la figura del Incidente de Impacto Fiscal, como un instrumento novedoso y reciente, que ha tenido un importante desarrollo jurisprudencial.

"Sobre esta materia, es importante destacar que esta figura jurídica recoge en un todo los principios presupuestales y se han visto materializados a través del desarrollo del criterio de Sostenibilidad Fiscal a través principalmente del Acto Legislativo 03 de 2011 y reconoce la escasez de los recursos públicos y pretende asegurar las condiciones para que el Estado garantice los derechos que son reconocidos por la Constitución Política”(ALZATE OCAMPO). 


\section{CAPÍTULO7}

\section{¿El Estado Fiscal en Colombia?}

Luego de esta amplia disertación acerca de la aprobación y aplicación del Acto Legislativo 03 de 2011 y su reglamentación mediante la Ley 1695 del 2013 cabe preguntarse en este punto: ¿Existe hoy una sustitución del Estado Social y Democrático de Derecho por un Estado Fiscal al cual se ha hecho referencia en acápites anteriores o simplemente coexisten en la realidad jurídica colombiana?

Las respuestas sin lugar a dudas deben ir ligadas al hecho de que se reformó la Constitución Política de 1991 a través de una Asamblea Nacional Constituyente en contradicción con la filosofía social que la motivó, sin recurrir al constituyente primario y sin la debida difusión que requería tan trascendental hecho y sin ceñirse totalmente al procedimiento que exigía dicha reforma.

El principio de Sostenibilidad Fiscalno permite hoy modificar sentencias de las altas cortes sin tener en cuenta a las personas afectadas o sus derechos jurídicamente reconocidos, cuando ello influya en el presupuesto.

Pareciera entonces superiores los cálculos del Ministerio de Hacienda, de Planeación Nacional y del Procurador General a las sentencias y los derechos fundamentales, pero estos como vimos no pueden ser menoscabados. 
La introducción del «incidente de impacto fiscal» tampoco viola los principios de separación de poderes y de autonomía o independencia de los jueces, porque la intervención de otro órgano del Estado, sin carácter judicial, no pretende reabrir, sin la presencia de los titulares de derechos afectados, un asunto ya decidido autónomamente por los jueces siguiendo los principios del debido proceso y la cosa juzgada.

La decisión judicial de amparar definitivamente derechos humanos y fundamentales es intervenida por la solicitud de otras autoridades no judiciales con razones económicas, para regular los efectos de la decisión, lo que incide directamente en el goce efectivo de dichos derechos por terceros afectados. (Arango, s/f, p. 2), pero como vimos la jurisprudencia en análisis en el presente trabajo presenta una tesis contraria.

Podría pensarse que al reabrir un proceso no ejecutoriado podría modificar su fallo sobre motivos económicos y en consecuencia, se podría perder la armonía entre poderes públicos, al priorizar las razones presupuestales con menoscabo de principios de autonomía de las ramas del poder público que ha garantizado la Constitución.

Al configurarse esta situación, ciertamente se podría afectar el Estado Social de Derecho en favor de un Estado Fiscal, utilizando para ello una transformación de la Carta Magna enfundada en la salvedad que presenta el artículo 334 de la Constitución modificado, cuando señala que "en ningún caso se afectará el núcleo esencial de los derechos fundamentales", mientras que en la prácticalas razones fiscales que presente el Procurador o los Ministros 
deHacienda,posibilitaríala afectación de los proyectos de sentencias judiciales en las que dichos derechos puedan ser reconocidos. Pero como vimos esta situación no se presenta.

No afectar el núcleo esencial de los derechos fundamentales es la condición primordial para que se pueda sancionar un Incidente de Impacto Fiscal, pero a su vez este principio está constituido para impedir que se ejecute una sentencia que avala precisamente este núcleo, mediante el reconocimiento de una compensación por la afectación de dichos derechos a un segmento de la población.

Al admitir lanegación de derechosfundamentales condicionados por límites fiscales la figura del Estado Social y Democrático de Derecho, no solo comparte jerarquía constitucional con el Estado Fiscal, sino que el Estado Fiscal de Derecho se podría sobreponer en la realidad constitucional,que desconocería igualmente tratados internacionales de derechos humanos ratificados por el Estado colombiano y representaría por razones macroeconómicas un retroceso en las garantías constitucionales de derechos a los ciudadanos que representa la real tesis de nuestra investigación al minimizar el impacto de la herramienta del Incidente de Impacto Fiscal.

¿Los fallos jurídicos que reconocen derechos fundamentales pueden representar un desequilibrio presupuestal y se requiere invocar el Incidente de Impacto Fiscal para garantizar la ejecutoriedad de diferentes obras sociales y el ejercicio de la estructura pública?¿Por qué motivo el gobierno nacional no incluyó dentro de las variables que inciden en un déficit presupuestal aspectos como el pago de la deuda externa o el presupuesto militar? Son preguntas sobre la orientación de las políticas públicas pero que no incide jurídicamente en el Incidente de Impacto Fiscal ya analizado. 
Según esta perspectiva y en teoría presupuestal, para el Estado es insostenible el reconocimiento mediante fallos jurídicos de los derechos fundamentales, más no las obligaciones financieras con el extranjero y el funcionamiento de la maquinaria militar que responde a políticas macroeconómicas que obligan a compromisos presupuestales que menoscaban los recursos para garantizar derechos en un Estado social.

Este escenario es incomprensible en un país como Colombia que en los últimos cinco años ha demostradoun crecimiento del PIB entre el 4 y 5\% y una disminución del nivel de endeudamiento.

Según esto, el déficit fiscal primaría sobre los derechos constitucionales y el Ejecutivo ha decidido asegurar su capacidad de ejecución, en detrimento de la garantía de los derechos fundamentales reconocidos, en lugar de afectar rubros mucho más significativos dentro del presupuesto nacional.

Señala el tratadista Arango (s/f):

La introducción del «incidente de impacto fiscal» desconoce, por último, la diferencia entre derechos (razones morales o de principio) e intereses generales (razones políticas o de conveniencia), lo cual hace saltar por los aires el Estado constitucional, democrático y social de derecho. (p. 3)

Ciertamente los derechos son muy diferentes a los intereses generales, así como son muy diferentes los derechos fundamentalesy la Sostenibilidad Fiscal. 
No puede admitirse que fallos jurídicos ceñidos a la Constitución se tengan que modular, revertir o modificar, porque posteriormente se convenga un examen fiscal y menos aun cuando están ausentes los afectados. El reconocimiento judicial de derechos sociales fundamentales debe ser un tema inalterable por políticas presupuestales y es una limitante del acto legislativo y de la ley que regula la Sostenibilidad Fiscal en Colombia.

El Estado colombiano no puede desconocer derechosligados a la dignidad de la persona, ya que no los crea el poder político sino una estructura normativa superior. Todo colombiano tiene derecho a la salud, a la educación, a la vida, a la libertad, al sufragio y a la libreasociación, entre otros, así como su respectiva compensación cuando se vean afectados estos derechos, sin importar que el gobierno tenga o no tenga dinero en sus arcas.

No se quiere afirmar por ello, que la prudencia y la moderación para evitar el excesivo endeudamiento público se deba desconocer y afectar los propósitos sociales, que pretende atender el presupuesto mediante un equilibrio fiscal, ello sería ilógico, pero si es necesario identificar la diferencia entre los derechos y las finanzas, porque nose pueden sustraer garantías a los colombianos y poder jurídico a los jueces mediante opiniones de las autoridades económicas y menos poner en igualdad de jerarquía al Estado Social frente al Estado Fiscal que es una herramienta de la esencia social de orden constitucional.

Es importante reiterar que en buena medida, esta situación se produce gracias a la globalización que se ha venido desarrollando en el mundo entero y a la cual Colombia no ha sido ajena. La globalización tiene gran responsabilidad frente a la generación del pensamiento 
económico-fiscal que promovió el Incidente de Impacto Fiscal en el país, que convirtió una estrategia o herramienta de hacienda pública en un "supuesto principio" que afectaría incluso al constitucionalismo en favor de la corriente economicista.

De esta manera, el Estado Fiscal podría superponerse al Estado Social de Derecho con un modelo fiscalistatrazado a la luz dela globalización neoliberal que promueve el Banco Mundial,que funda su desarrollo en lainversión de las multinacionales y en particular delcapital financiero, que traslada la responsabilidad de los desequilibrios a los contribuyentes, tal como expone Téllez (2010), pero esta es otra discusión respecto al Incidente de Impacto Fiscal:

Estamos ante un modelo de sostenibilidad de las finanzas públicas que descarga el costo de la crisis fiscal sobre las capas medias y pobres, fundamentalmente a través del incremento de los tributos indirectos y del recorte de la inversión social en los momentos de crisis fiscal. Modelo de sostenibilidad fiscal que al montar el desarrollo sobre la inversión de las multinacionales y en particular del capital financiero (en gran parte capital golondrina) tiene que ofrecerle condiciones de ganancia altamente favorables para hacer competitivo al país en el mercado internacional de capitales. Ello implica, como una consecuencia estructural del modelo, que la población tenga que asumir a favor de la inversión extranjera el alto costo fiscal de garantizarle "seguridad democrática", exenciones, deducciones, abolición del impuesto patrimonial, eliminación de impuestos a la remesa de utilidades, seguridad jurídica tributaria y particularmente, la reducción al mínimo de los costos laborales. En estas circunstancias, el modelo obliga a descargar progresivamente el costo fiscal sobre el consumidor, sobre la privatización del patrimonio público y sobre la deuda pública cuyo servicio absorbe cerca del $40 \%$ del presupuesto nacional y cuyo estricto 
cumplimiento constituye un dogma para nuestros gobiernos, en detrimento del desarrollo y el bienestar de los colombianos. (p. 4).

Con esta perspectiva se cambian las prioridades del Estado de acabar con el desequilibrio social a garantizar la Sostenibilidad Fiscal, elevadamediante el Acto Legislativo 03 de 2011al rango de mandato constitucional como instrumento de racionalización del gasto público.

“El Estado Fiscal en el que se inscribió el país, quedó definido por la reforma a la Constitución y las nuevas reglas socialesamarradas a partidas presupuestales, las cuales establecen que "no podrá haber ordenación, ni ejecución de gastos por ninguna rama, órgano o funcionario del poder público que no esté contemplado en el Plan Nacional de Desarrollo y en la Ley de Apropiaciones del Presupuesto Anual de la Nación" (Téllez, 2010, p. 5).

Así pues, el Estado Social de Derecho, podría quedar supeditado al presupuesto, a la cantidad de impositivos que acumule el gobierno y a las partidas estimadas para su gasto, cualquier otra erogación que signifique un gasto no contemplado queda sin base, incluso si se trata de reconocer derechos fundamentales a la población.

Esta realidad del Estado Fiscal, conduciría a su vez a una trasgresión en los límites de los poderes de las ramas del poder público, al primar las decisiones del Ejecutivo, sobre las que imparte el Judicial a través de proyectos de tutelas falladas en favor del Estado Social de Derecho, como bien lo expresa Téllez (2010), pero que con las características del Incidente de Impacto Fiscal no podría ser posible: 
Las leyes de la naturaleza quedan así, reguladas y supeditadas a la ley de la sostenibilidad fiscal, del equilibrio de las finanzas públicas, del equilibrio fiscal. No es tampoco la realidad de la sociedad la que determina las obligaciones del Estado, sino la regla fiscal la que cuadricula la realidad social. Esto, en un país en el que el $70 \%$ de la población ha sido colocada en los rangos de pobreza y miseria. Pero además, es esta la población que debe sacrificar sus necesidades vitales en beneficio del gran capital. (p. 5)

Al realizar un análisis más profundo de esta situación, se puede vislumbrar que el Estado Fiscal al que hemos sido abocados, tiene sus orígenes en las políticas que el Banco Mundial que ha venido sugiriendo al país respecto a incrementar los impuestos para poder cumplir con las obligaciones de deuda pública,que acude a reformas tributarias y a reorganizar las transferencias a las entidades territoriales con el objetivo de sustentar el Tratado de Libre Comercio con Estados Unidos y, ante todo, para reformar las leyes de presupuesto para limitar las asignaciones específicas con las implicaciones negativas sobre fortalecimiento de finanzas públicas y generación de empleo.

En una columna "Colombia y el modelo de desarrollo del rebusque", de la reciente Revista Dinero No 494 del 27 de mayo de 2016, Juan Manuel López Caballero, expresaba sobre la materia:

“...la columna vertebral suponían ser los Tratados de Libre Comercio, TLC, en especial el suscrito con los Estados Unidos, pero i se crearon los centenares de miles de empleos proyectados (seguimos teniendo uno de los desempleos más altos del continente-sino el más alto-); ni disminuyeron las importaciones de allá... ni aumentaron las exportaciones y se desfasó la balanza cambiaria equivalente al 
6.5\% del PIB...y rompemos el record histórico de la deuda externa. Del fracaso del modelo neoliberal pasamos a un modelo de minería extractiva de venta de nuestros recursos naturales, sobre todo alrededor del petróleo...el gobierno se dedica a las improvisaciones y al rebusque”. (López Caballero: 2016).

La crisis fiscal tiene entonces una naturaleza estructural por las equivocaciones macroeconómicas de las políticas económicas y por los elevados gastos públicos en el sector defensa ante el conflicto armado interno, en especial durante los ocho años de la Política Democrática de Seguridad, donde el Estado social debió ceder al valor de la seguridad y los derechos del Estado social han sufrido restricciones en su garantía y materialización.

Claro está que a ello debe sumársele la cultura de corrupción administrativa que caracteriza a la estructura pública colombiana hace décadas. Todo esto conlleva a un déficit presupuestal que promueve el Estado Fiscal, a la luz de la globalización neoliberal que ha adoptado el país y que transfiere ahora a los estratos más bajos la carga del déficit, condenándolos al desconocimiento de sus derechos y ser insertados en la ampliación de la base tributaria.

Durante cerca de un cuarto de siglo de imposición violenta del inhumano modelo de la globalización neoliberal, el Estado ha estimulado la concentración y acumulación del gran capital interno e internacional, transfiriéndole la propiedad social, promoviendo las concesiones, sacrificando el ingreso de los trabajadores, estimulando o siendo cómplice de la concentración de la tierra por el narco-paramilitarismo, las multinacionales y los terratenientes, mediante el desplazamiento violento, brindándole al gran capital seguridad militar, desarrollo de la infraestructura, exenciones y deducciones, adecuación de la 
institucionalidad, estabilidad jurídica y tolerancia absoluta de la corrupción. Es decir que la acumulación se ha beneficiado de la violación sistemática de los derechos humanos. (Téllez, 2010.p. 6)

Así como dentro del discurso económico-fiscal que el gobierno diseñó para establecer la figura del Incidente de Impacto Fiscal,no se habla del pago a la deuda o el gasto militar como rubros considerables que pesan en el presupuesto y que pueden tener un mayor poder de desequilibrio fiscal que el reconocimiento de derechos mediante proyectos de fallos de tutela.

De igual forma, tampoco se menciona el excesivo gasto público y la amplia corrupción administrativa existente en el país y que sin lugar a dudas, conciben una enfermedad a las finanzas públicas, con mayores efectos negativos que las decisiones en derecho a la luz de la Constitución o de herramientas como las del Incidente de Impacto Fiscal.

Sería un tema demasiado amplio citar aquí las cifras del sinnúmero de inversiones del Estado colombiano en su historia reciente, que han sido onerosas, injustificadas o mal ejecutadas, así como también un tema de nunca acabar ante la gran cantidad de carruseles y carteles de la contratación que se aferran a todos los niveles del sistema público, como parásitos que desangran las finanzas públicas.

Ellos seguramente constituyen una fuente de desequilibrios fiscales mucho mayor, que los fallos que reconocen indemnizaciones a poblaciones afectadas en sus derechos. 
El Estado Fiscal que surge hoy es producto de desequilibrios que han venido suscitándose por años y que con la reforma constitucional pretende el gobierno contener a costa de la responsabilidad social que le compete.

Estar inscritos en este modelo favorece la concentración del capital nacional y el incrementode las utilidades del capital extranjero que no se queda en el país, lo cual amplia la brecha social y por ende el incremento de la pobreza y la exclusión que patentiza un modelo político ya descrito como neo conservador e inserto en políticas de extracción minera con el cual se dio inicio al presente trabajo y se fundamenta con conceptos técnicos autorizados en la materia.

El Estado Social y Democrático de Derecho dentro del modelo de globalización liberal no es negocio viable para el gobierno, porque en la medida que los jueces reconocen derechos en virtud de la Constitución garantista de derechos, se le agudiza al Estado la crisis fiscal y la vía para solucionar este vacío es coartandolos mismos derechos y desconociendo fallos. En este sentido ha denunciado el Senador Jorge Enrique Robledo (citado por Pérez, s/f, p. 103):

"La Sostenibilidad Fiscal dará un duro golpe a los derechos sociales de la Constitución Política, es una ley profundamente retardataria. La Constitución de 1991 tiene una doble naturaleza, pues por un lado otorga a los colombianos una serie de derechos, entre ellos el de la tutela, y al mismo tiempo le da piso jurídico al neoliberalismo, y al libre comercio, principal causa de la crisis en que se halla sumido el país”. 
Tal como se ha advertido, no es completamente cierta esta afirmación. Desde el punto de vista económico y estructural contiene una verdad con el destino de las finanzas públicas, pero desde el punto de vista funcional-jurídico el Incidente de Impacto Fiscal, no representa el desconocimiento de derechos.

Ahora pues, desde el punto de vista de la teoría jurídica, según Guerrero (2012), el "Principio de Sostenibilidad Fiscal" no corresponde en toda su extensión a lo que se podría considerarse como un "principio", sino más bien a una "directriz" o un "instrumento" según la jurisprudencia citada en acápites anteriores, con las siguientes características:

“i) se trata de una norma restrictiva de los "bienes protegidos" por algunos derechos fundamentales, o, lo que es lo mismo, restrictiva del núcleo esencial de algunos derechos fundamentales o principios, tales como la salud, el mínimo vital, la educación, el trabajo, la vivienda digna, etc. Lo anterior, en razón a que, como lo anotó $\mathrm{Alexy}^{3}$, las restricciones a los derechos fundamentales son normas constitucionales (se enfatiza que deben ser de rango constitucional; tal es el caso sub examine) que restringen las posiciones prima facie de derecho fundamental. De acuerdo con lo anterior, si el supuesto principio que se analiza se contrapone a un derecho fundamental, la interpretación constructiva de Dworkin, ${ }^{4}$ "que trata de imponer un propósito a un objeto o práctica para hacer del mismo el mejor ejemplo posible de la forma o género al cual se considera que pertenece [...]”, deberá hacer prevalecer aquella solución que consulte de la mejor manera la garantía y la protección del derecho fundamental, en detrimento de la sostenibilidad fiscal;

\footnotetext{
${ }^{3}$ El autor hace referencia al texto de Alexy, Robert (2007). Teoría de los derechos fundamentales. Madrid: Centro de Estudios Políticos y Constitucionales.

${ }^{4} \mathrm{El}$ autor hace referencia al libro de Dworkin, Ronald (1992). El imperio de la justicia. Barcelona: Gedisa.
} 
ii) la directriz, al oponerse a otros verdaderos principios, tendría que ser excluida, y el conflicto normativo deberá solucionarse como un conflicto de reglas. Un conflicto de reglas se resuelve, según Alexy, mediante la introducción en una de las reglas de una cláusula de excepción que elimine el conflicto”. (p. 26)

De esta manera mediante esta "directriz" las autoridades administrativas redefinen decisiones del judicial,pero como se ha observado es un procedimiento estrictamente reglado que no permite esta afectación sobre verdaderos principios jurídicos para garantizar los derechos fundamentales y la justicia.

El "Principio de Sostenibilidad Fiscal" al no corresponder jurídicamente al concepto al que pretende asociarse, no posee las características para elevarse al nivel de principio y no consigue el criterio para suscitar una reforma constitucional.

A diferencia del "Principio de Sostenibilidad Fiscal" la independencia judicial junto con los principios de legalidad y de tridivisión de poderes sison considerados como principios básicos del Estado de Derecho, así mismo respecto a la independencia judicial que se encuentran asociados los principios de legitimidad y capacidad y sobre los cuales la Corte Constitucional ha sido amplia y concreta en establecer el respeto al principio de autonomía y colaboración armónica.

Esta confusión en la definición del concepto también “implica una confusión de funciones entre el Gobierno y la judicatura, que a la postre resulta inconstitucional” Guerreo (2012, p. 29). 
Cada rama del poder público tiene la asignación de determinadas funciones, pero la intromisión del Ejecutivo en materia exclusiva del Legislador, representaría una inestabilidad jurídica, porque al tener el poder a través del Incidente de Impacto Fiscal de modificar proyectos de fallos, las garantías para administrar justicia se reducen y el papel de los jueces se ve afectado.

Se ha visto que esta circunstancia jurídica no es procedente. De igual manera en este escenario los jueces deben entonces proferir sus decisiones ateniéndose al presupuesto de la nación o los diferentes entes municipales, para definir hasta qué punto pueden o no reconocer derechos fundamentales a los colombianos, que según el ejercicio contable del gobierno en pocas ocasiones se podrán reconocer al estar comprometido el presupuesto en los diferentes proyectos de desarrollo y el funcionamiento público.

Esta circunstancia, podría originaruna confusión de funciones entre el Gobierno y la judicatura, que a su vez resulta inconstitucional, pero como vimos no se presenta.

Los jueces en su función de promover la justicia son los principales depositarios de la confianza pública para garantizar los derechos sociales, económicos y culturales, mediante decisiones judiciales para garantizar los derechos fundamentales, que a diferentes segmentos de la población se les desconocen o se les violan, más aún en un contexto de violencia y conflicto armado interno por más de medio siglo. 
Dentro de este esquema donde prima el equilibrio fiscal el reconocimiento y reparación de víctimas es una tarea difícil de lograr, lo que sin lugar a dudas significa un gran obstáculo para alcanzar un escenario de posconflicto donde exista una verdadera reintegración social. Lo anterior implica un gran desafío para los próximos gobiernos, al definir sus planes de desarrollo y sus políticas públicas debidamente presupuestadas, razones que llevaría a un uso razonable de los Incidentes de Impacto Fiscal.

En este sentido la Sentencia T-585 de 2008 señala:

Los derechos sociales, económicos y culturalestraducen necesidades históricamente desconocidas respecto de sujetos que, en atención a las circunstancias particulares en las que se encuentran, se han visto privados de la posibilidad de ejercer la libertad que animó la constitución del Estado de Derecho y que bajo la fórmula del Estado Social es nuevamente reivindicada, esta vez, tras el replanteamiento del concepto mismo de libertad que en adelante reconocerá como prerrequisito de su goce a la igualdad, entendida ya no en el sentido formal clásico sino como mandato dirigido al Estado en cuanto organización política encargada de la satisfacción de las necesidades básicas, con la intención última de asegurar a los ciudadanos una vida en condiciones respetuosas de la dignidad humana.

Estos derechos en la actualidad se ven afectados adicionalmente por el principio de sostenibilidad fiscal que facilita el desconocimiento de los derechos de los colombianos, en especial de las clases menos favorecidas y de todos aquellos que han vivido el conflicto armado en carne propia y que desgarra la tragedia nacional. 


\section{Conclusiones}

Tal como se ha podido establecer a través del marco teórico jurídico que guía la presente investigación a partir de su inicio, el concepto del Estado Social y Democrático de Derecho asumido en Colombia mediante la reforma constitucional del año 1991, es una nueva visión de equidad, justicia y participación sobre la cualse basa el desarrollo del país y más que ello, para la garantía de los derechosdonde coexiste con un modelo político mixto entre lo social y lo económico como se ha descrito en acápites ya vistos, o mejor, que presenta una dicotomía entre las concepciones del Estado formal de derecho y el Estado social y democrático de derecho y que se mueve entre su jerarquía constitucional frente a los avances del Estado Fiscal.

El concepto tiene una muy clara perspectiva hacia la necesidad de que el derecho esté en función del bienestar del hombre y no de manera viceversa, para lo cual se han venido generando grandes cambios en la legislación nacional en pro de consolidar esa nueva figura de Estado, centrada en el conjunto de matices que conforman la seguridad y afianzamiento del ser humano y su desarrollo, objetivos principales del Estado social frente a los desafíos macroeconómicos sustentados en las políticas del vigente Estado fiscal.

De esta forma, el trabajo es amplio en señalar la prioridad que representa la cristalización de un verdadero Estado Social y Democráticode Derecho para el cumplimiento de la carta de navegación jurídica establecida a principios de los noventa y, para el logro de un desarrollo humano para Colombia. 
De igual manera, no se puede desconocer que el bienestar social deseado para el país exige de grandes recursos económicos y de una correcta utilización del erario para adelantar los proyectos de desarrollo y el funcionamiento de la estructura pública.

No obstante, la economía no debe convertirse en un limitante para que se logre justicia, es decir, que los recursos definidos a través del presupuesto público para las diferentes regiones, departamentos, ciudades, municipios y entidades no puede convertirse en un parapeto para excluir derechos reconocidos por jueces de la república y modificar sentencias de la Corte mediante actos administrativos, donde igualmente se ve afectado negativamente los avances de la descentralización fiscal.

El Acto Legislativo 03 de 2011 es muy claro en cuanto a que bajo ninguna circunstancia, autoridad alguna de naturaleza administrativa, legislativa o judicial, podrá invocar la Sostenibilidad Fiscal para menoscabar los derechos fundamentales, restringir su alcance o negar su protección efectiva.

Transformar estos fallos en derecho y determinar que por cuestiones de presupuestos las sentencias puedan modificarse, representa construir un nuevo proceso sobre una cosa ya juzgada que contraviene los principios constitucionales y los derechos ciudadanos.

Es atentar abiertamente contra el Estado Social y Democrático de Derecho, pues las víctimas y afectados por diferentes acciones u omisiones del Estado, en especial todas aquellas que corresponden a más de cincuenta años de conflicto armado, dentro de esta perspectiva nunca 
van a tener reconocimiento y menos aún una reparación en pleno proceso de pos conflicto que requiere de una atención especial para los sectores más vulnerables de la sociedad para contra restar el fenómeno de la inequidad, primera en América latina.

En consecuencia, la Sostenibilidad Fiscal se ha convertido en un medio jurídico para que el Estado evada su responsabilidad económica y social frente a diferentes comunidades afectadas, las cuales han logrado en la mayoría de casos mediante largos y tortuosos procesos el justo reconocimiento de sus derechos, avalados por un fallo en derecho ordenado por la autoridad judicial correspondiente.

Hoy día buena parte de estos procesos se están quedando sin un acatamiento y cientos de personas condenadas a la injusticia debido a que el Estado no tiene el capital para entregar las indemnizaciones que la Corte determina, lo cual es una situación inadmisible desde el punto de vista del Estado Social y Democráticode Derecho, la ética pública y la justicia social.

No es posible desarrollar un análisis objetivo de todo lo expuesto cuando no se puede ocultar la realidad y pretender establecer una mirada pragmática frente a la capacidad del Estado y su responsabilidad para generar desarrollo y garantizar derechos.

El presupuesto público está compuesto por partidas de capital claramente definidas y asignadas para distintos proyectos y el funcionamiento público, que supone la base para adelantar obras que mejoren la calidad de vida y el bienestar de los colombianos en las diferentes regiones del país. 
Pensar en indemnizar automáticamente a los cientos y miles de víctimas de diferente índole que posee este país, en especial a causa del conflicto armado interno, es un escenario inviable económicamente, pues comprometería el desarrollo nacional y la paz en el denominado posconflicto o pos acuerdo del conflicto armado que se debate en la Habana entre el gobierno nacional y el grupo armado de las FARC-EP próximo a suscribirse por las altas partes negociadoras, aunque no por ello se deban desconocer los derechos de los colombianos que constituyen víctimas, al modificar los fallos jurídicos o de plano decidir, que no habrá lugar a la compensación a las víctimas que ascienden a más de siete millones de colombianos.

Todo lo expuesto, es un reto para los desarrollos de la justicia social frente al Incidente de Impacto Fiscal, o por lo menos, constituye otro reto para la paz social del país que refleja los valores de justicia y razón del Estado social y democrático de derecho.

Los derechos no son negociables a través de prórrogas presupuestales para temas tan delicados y sensibles para la sociedad colombiana como acontece con la Ley 1448 de 2011 o Ley de Victimas analizada como caso examen en la presente tesis frente a la Sostenibilidad Fiscal y las políticas macroeconómicas.

Su aplazamiento, es el aplazamiento del denominado posconflicto colombiano.

Los fallos jurídicos no deben ser modificados de manera administrativa o de lo contrario el Estado Social y Democrático de Derecho se verá afectado seriamente ante los compromisos 
macroeconómicos de la política fiscal inspirada en la doctrina neoliberal y que responde a la voluntad de las Administraciones de turno.

Si dentro de un año fiscal el presupuesto de las diferentes entidades u organismos públicos no poseen los recursos para dar cumplimiento a los fallos, lo más lógico es que dentro de los presupuestos futuros se deba incluir el pago parcial o total de estas responsabilidades como una acreencia más del ejercicio contable dentro de la actividad pública, hasta saldar la deuda contraída mediante sentencia judicial.

Finalmente, es preciso indicar que todos necesitamos de la sostenibilidad fiscal para promover las obras de carácter público frente a la teoría de Robert Alexy sobre el racionamiento de los bienes públicos entre todos los peticionarios. El problema en Colombia es que esta eventualidad política no se manifiesta por la precaria participación y toma de decisiones en los asuntos públicos o de todos.

Pero se debe tener muy claro que sin justicia social (derechos más libertades), nunca habrá un verdadero desarrollo humano para el país. Si éste, tiene restricciones en sus decisiones en especial por la cooptación el sistema político representativo respecto a las políticas públicas referidas a la justicia social y a las consideradas como casos juzgados por una rama como la judicial que reviste autonomía en ejercicio de una precaria, lenta e ineficiente administración de justicia distributiva entre partes el panorama será sombrío y conflictivo y este será un tema de debate entre el poder y el derecho para las próximas décadas. 
El porvenir social no es el mejor y los vientos del neoliberalismo se cimentan desde las políticas oficiales macroeconómicas que consolidan el poder de la rama ejecutivaen el poder público colombiano, que a su vez mantiene la formulación del Estado formal de derecho y el statu quo de la exclusión social que acude a análisis funcionalistas del fenómeno político y jurídico.

En este sentido, las palabras modular, modificar y diferir, admitidas por la propia Corte Constitucional frente a la declaratoria de constitucionalidad del Acto Legislativo 03 de 2011, sobre el instrumento de Sostenibilidad Fiscal, constituyen en nuestro criterio tecnicismos fundados en razones macroeconómicas donde los afectados son los ciudadanos más excluidos del desarrollo nacional poblado en los entes territoriales y zonas urbanas más deprimidas, así se pregone el modelo Shumpeteriano citado inicialmente, como solución a la garantía de derechos en un Estado social que comparte escenario con el modelo capitalista que proyecta el Estado Fiscal.

Por esta razón, no coincidimos conceptualmente con los fallos de la Corte Constitucional citados en el texto de la tesis como demostración de la figura del Incidente de Sostenibilidad Fiscal, pues los principios esenciales del Estado social no pueden aparejarse a presuntos principios en materias fiscales.

El Estado Fiscal no puede imponerse al Estado Social y Democrático. Puede servir para los ajustes macroeconómicos o para sanear las finanzas públicas, pero nunca, para redistribuir 
derechos lo cual nos plantea la dicotomía conceptual entre las expresiones jurídicas del Estado formal de Derecho y el Estado Social y Democrático de Derecho.

Por esta misma consideración, a lo sumo se trata de un instrumento de progresividad en las políticas fiscales del país por razones macroeconómicas y de supuesta eficacia del gasto público a riesgo de ahondar la brecha de la inequidad.

Según el documento de trabajo de investigación titulado "Incidencias negativas del principio de sostenibilidad fiscal en los fallos por responsabilidad patrimonial del Estado y los de tutela" de Gisella Rosa y otros de la Universidad Libre de Colombia publicado en verba iurisestudiantil-Volumen 1-artículos sobre Derecho Público Financiero- y con el cual coincidimos, el incidente de impacto social generará en el futuro un verdadero choque de trenes entre la rama judicial y la rama ejecutiva, toda vez que como ya se dijo, se atenta claramente contra la autonomía de la rama judicial, al crear una nueva instancia frente a la cosa juzgada, pues lo que se debatirá por medio de este, serán circunstancias de fondo ya analizadas en la sentencia y que se entra a revisar por un incidente de un organismo de control como la Procuraduría General de la Nación o de la rama ejecutiva de naturaleza administrativa, en contra de una decisión judicial que goza de plena autonomía.

"La asignación de derechos de última generación por la justicia constitucional es ineficiente por que no dispone de criterios de asignación que permita priorizar necesidades y méritos, porque tiene efectos redistributivos que son ineficientes y porque da a los ciudadanos incentivos indeseables...el Estado social de derecho solo puede lograrse si los recursos alcanzan para pagarlo. Y es más probable que los recursos 
alcancen si el sistema político-económico colombiano induce a los habitantes del país a usar sus energías creativas para la generación de bienestar que si los acostumbra a medrar por cuenta de las concesiones de la jurisprudencia.

El problema es escoger entre repartir ya mismo entre múltiples intereses y expectativas lo poco que tenemos, sin criterios ni prioridades coherentes, ni noción del alcance de los recursos disponibles, o encargar al Estado de los bienes públicos y permitir que cada grupo de interés filtre sus pretensiones redistributivas a través del proceso político y de las restricciones técnicas del presupuesto, dejando el resto del espacio normativo para los acuerdos privados (inter partes). Esta segunda opción seguramente no parecerá tan inspiradora y moralmente deseable como la primera, pero funciona mucho mejor" (Núñez, páginas 36 y 37).

Sobre estas premisas del autor citado, estamos parcialmente de acuerdo y nos inclinamos mejor en cómo encontrar las salidas a la distribución de la justicia deseable con la intervención de los ciudadanos a través de una democracia más incluyente, participativa y deliberativa que pugne por la justicia social del interés general tutelado constitucionalmente con el cual dimos entrada a la tesis y donde la justicia distributiva de los jueces consulte los altos intereses estatales del bien común del buen razonamiento que tratara Amartya Sen, en su obra "La idea de la Justicia":

"Lo que más importa es el examen de qué exigiría la razón en la búsqueda de la justicia, habida cuenta de la posibilidad de que existan varias posiciones razonables distintas”. (Rawls, pág. 22).

La tesis ha desarrollado las dos posiciones para la materialización del Estado Social y Democrático de derecho, pretendiendo encontrar la más razonada como ejercicio académico para 
optar por el título de magister en derecho público y respaldar nuestra principal conclusión en las siguientes consideraciones:

"La respuesta es, entonces, por la consolidación de una auto legislación democrática en donde todos los ciudadanos son productores del derecho que los rige como sujetos políticos y jurídicos; de esta manera, las libertades subjetivas de acción del sujeto de derecho privado se corresponden con la autonomía pública del ciudadano con inclusión del otro mediante la opinión y la voluntad estructurada democráticamente para posibilitar un acuerdo normativo racional entre extraños” (Jiménez, A pág. 130).

Es decir, entre socialdemócratas de una parte y neoliberales de otra, en un Estado Social y Democrático de Derecho, que defienden en su orden el Estado social Keynesiano y el Estado Fiscal shumpeteriano, como desarrollo temático frente a la figura jurídica de la Sostenibilidad Fiscal macroeconómica frente a la justicia social y su impacto en las decisiones de los jueces en Colombia como justicia distributiva entre partes, acorde con una hermenéutica argumentada y de test razonado frente a la esencia del Estado Social.

Todo lo anterior, sin antes advertir que coincidimos parcialmente con el autor Antonio José Núñez, cuando en la obra citada atrás, expresaba a página 59, que de acuerdo con la sentencia SU-111 de 1997 de la Corte Constitucional, el Estado social de derecho no puede prescindir del proceso democrático cuando las sentencias de los jueces no consulten el fundamento legal y presupuestal de sus decisiones y que cuando esta situación suceda, se corre el riesgo de convertirse en un estado judicial totalitario (Derecho de los jueces o Estado de normas) que 
extirpa la función a los otros órganos del Estado y a los ciudadanos mismos como dueños de su propio destino de garantía del orden social.

Esta tesis es válida, siempre y cuando el sistema político y económico, permita el noble camino de la construcción de sujetos políticos con amplia participación en los asuntos de todos conforme a las tesis de Abendroth y Habermas, como proceso democrático en construcción y desarrollo en las próximas décadas para encontrar la justicia en términos de equidad y mediante juicios de valor y de justicia social, argumentados y debidamente valorados o deliberados.

El problema lo plantean los programas de estabilización de la macroeconomía que fundamentan el neoliberalismo cuando se desmontan las políticas sociales de las políticas públicas de los gobiernos mediante la racionalización del gasto público,y cuando contravienen la inversión pública en programas claves para el desarrollo humano que respaldan la protección de los derechos fundamentales y los considerados Derechos Económicos Sociales y Colectivos, o de última generación, tan necesarios e inaplazables en los procesos de democratización a largo plazo en una sociedad excluyente como la colombiana que sigue regida por una concepción formal del Estado de Derecho o simple Estado de normas.

En Colombia no se ha logrado desarrollar la concepción de justicia y razón que la colectividad realmente tiene como postulado Rawlseniano respecto a la expresión de una justicia con equidad o de justicia comparativa que planteara G A Cohen en su texto Justicia y Equidad escrito en 2008, a través de la concesión de incentivos o de plena autonomía la función 
productiva, o que se planteara en su momento histórico Abendroth, con su enfoque estructuralista con que dimos inicio a la presente tesis.

Coincidimos con este último autor, sobre las amenazas que se ciernen frente a la materialización del Estado social frente al Incidente de Impacto Fiscal, cuando sea utilizado por la Administración y el legislativo para procurar políticas macroeconómicas que resultan afectando derechos sociales y económicos de los ciudadanos., pero que jurídicamente de acuerdo con la legislación prevista en la materia ello no sería posible.

Podríamos igualmente cuestionarnos sobre la neutralidad de los gobiernos dada la organización socioeconómica del país garantizada igualmente por el orden constitucional en Colombia, regida por monopolios y oligopolios cuyas decisiones no siempre terminan consultando las bases democráticas del poder constituyente, que por el contrario culminan otorgando razón a los postulados de Forsthoff, cuando se pase por encima las ideas de justicia asociadas al derecho, es decir a la justicia social, que cada gobierno interpretará frente a la facultad de formular las políticas macroeconómicas como racionalidad del formal Estado de Derecho jurídico y racional, que sigue vigente en Colombia y que confronta la realidad del orden social que protege el Estado social que defiende conceptualmente Abendroth de manera estructural.

La justicia social en Colombia al igual que en países periféricos del gran capital tiene como enemigo fundamental a la libertad del mercado que cuenta con apoyo de gobiernos convencidos de la democracia capitalista que renunciaron al intervencionismo de Estado. De esta manera, se plegaron en contrario a la libertad de mercado como expresión de justicia y 
razón,pero donde el Incidente de Impacto Fiscal, de conformidad con todas las razones expuestas de orden estructural y funcional, no representa un peligro para el desconocimiento de derechos y donde pueda pensarse que se constituyeen un gran aliado de laexpresión del Estado de Derecho o de normas.

Por el contrario, son las formulaciones funcionalistas de la macroeconomía influida por la globalización los que sí pueden constituir las razones estructurales de la negación o limitación de los derechos, que se justifican por razones macroeconómicas y por fortalecimiento de la hacienda pública.

Colombia, está definida como sistema político social demócrata en su Constitución, pero se enfrenta a una gran realidad en sus estructuras políticas a las cuales se han dedicado gran parte de la investigación para demostrar su incidencia en el Estado social de derecho que antecede.

Colombia, igualmente se ha concebido como una sociedad modelada al mejor estilo de un neo conservadurismo, y esas dos tendencias, tienen honda interpretación ideológica cuando se parte de análisis estructuralistas o bien funcionalistas a los cuales se han dedicado igualmente unas consideraciones que determinan el Estado social y democrático de derecho o bien un Estado de derecho o Estado de normas, para la garantía relativa de derechos, bienes y servicios por parte del Estado, a través de los gobiernos y sus administraciones públicas con determinaciones de ajustes fiscales a través más de las políticas macroeconómicas que las propias en las cuales puedan incidir los Incidentes de Impacto Fiscal, objeto de la investigación, respecto de la materialización del Estado social de derecho. 
Sin ampliar las concepciones políticas que se expresan en el debate político y en el ejercicio del poder sobre estas dos concepciones, debemos concluir que sin eliminar las contradicciones que ofrece uno y otro modelo político constitucional y al coexistir las dos tendencias en nuestro ordenamiento superior como quedo visto, los gobiernos plantean espacios de colaboración entre propietarios, trabajadores y empleados, sin que exista una solución definitiva, y esa es la democracia en construcción en Colombia cualificada como imperfecta e incompleta para lograr la plena garantía de derechos.

Este ha sido el norte de las democracias de occidente y ésta ha sido la guía constitucional descrita a lo largo de nuestra investigación, que ha demostrado las amenazas de una concepciones de un modelo económico más que las potenciales o reales representadas en un instrumento fiscal, como la Sostenibilidad Fiscal frente a la concepción y naturaleza del Estado social, que a su vez convive con una economía de mercado que responde a los parámetros internacionales de la globalización y de las políticas de extracción minera , imposibles de sustraer o confrontar, y que incide en la garantía de derechos de los ciudadanos, dada la ausencia de intervención del Estado para la contención de la exclusión económica y que el Incidente de Impacto Fiscal no constituye una amenaza real a la esencia constitucional del Estado social ampliamente expuesto como quedó descrito.

En términos generales, como se ha advertido en el desarrollo temático propuesto, durante toda la historia de 200 años como inicialmente se expuso, con el pretexto del llamado al orden, a las razones de Estado, a la unidad nacional y a combatir la inflación; se han 
generado procesos y desarrollos constitucionales como el de la Sostenibilidad Fiscal a través del Incidente de Impacto Fiscal en un Estado Social y Democrático de derecho, mediante un acto legislativo y su desarrollo legal que dimensiona las características del Estado Fiscal, pero que no alcanza a afectar la esencia del Estado Social, y no podría limitar estructuralmente en consecuencia la garantía delos derechos, bienes y servicios, garantizados por autoridades judiciales para los más excluidos, que si son a su vez relativizados,por una democracia en ciernes, imperfecta y en desarrollo de construcción bajo los parámetros macroeconómicos antes citados.

\section{Referenciasy Citas Bibliográficas}

\section{LEYES}


Colombia (2003). Ley 819 de 2003. Por la cual se dictan normas orgánicas en materia de presupuesto, responsabilidad y transparencia fiscal y se dictan otras disposiciones.Diario Oficial 45243 de julio 9 de 2003

Colombia (2013). Ley 1695 del 17 de 2013. Por medio de la cual se desarrolla el artículo 334 de la. Constitución política y se dictan otras disposiciones. Diario Oficial 49.007 de diciembre 17 de 2013.

Colombia. (2011). Acto Legislativo 03 de 2011. Por el cual se establece el principio de la sostenibilidad fiscal.Declarado exequible por la Corte Constitucional mediante Sentencias C-288 y C-332 de 2012.

Constitución Política de Colombia (2014) Edit. Temis, Bogotá, Colombia

\section{SENTENCIAS DE ALTAS CORTES}

Colombia. (1995). Sentencia C-566 de 1995.Demanda de inconstitucionalidad contra el numeral 8 (parcial) del artículo 89 y el numeral 6 (parcial) del artículo 99 de la Ley 142 de 1994 "por la cual se establece el régimen de los servicios públicos domiciliarios y se dictan otras disposiciones. Corte Constitucional. M.P. Eduardo Cifuentes Muñoz. 
Colombia. (1998). Sentencia SU-747 de 1998. En el proceso de tutela T-152455, instaurado por Jorge Eliecer Raza y otros, contra el Registrador del Estado Civil de Santiago, en el departamento de Putumayo. Corte Constitucional. M.P. Eduardo Cifuentes Muñoz.

Colombia (2000). Sentencia C-1433 de 2000.Demandas acumuladas de inconstitucionalidad contra la Ley 547 de 1999.Corte Constitucional de Colombia. MP.Antonio Barrera Carbonell

Colombia (2001). Sentencia C-579 de 2001. Acción pública de inconstitucionalidad. Corte Constitucional. M.P.Eduardo Montealegre Lynett

Colombia (2001). Sentencia C-1064 de 2001. Acción pública de inconstitucionalidad. Corte Constitucional. M.P. Manuel José Cepeda Espinosa y Jaime Córdoba Triviño (S.V., Magistrados Jaime Araujo Rentería, Alfredo Beltrán Sierra, Rodrigo Escobar Gil y Clara Inés Vargas Hernández).

Colombia (2003). Sentencia C-1064 de 2003. Demanda de inconstitucionalidad parcial contra el artículo 684 del Código de Procedimiento Civil. Corte Constitucional. M.P. Manuel José Cepeda Espinosa y Rodrigo Escobar Gil

Colombia (2004). Sentencia C-931 de 2004. Demanda de inconstitucionalidad contra el artículo $2^{\circ}$ de la Ley 848 de 2003, "por la cual se decreta el Presupuesto de Rentas y Recursos de 
Capital y la Ley de Apropiaciones para la vigencia fiscal del $1^{\circ}$ de enero al 31 de diciembre de 2004. Corte Constitucional. M.P.Marco Gerardo Monroy Cabra

Colombia (2008). Sentencia T-585 de 2008. Acción de tutela contra la dirección de atención y prevención de emergencias-Solicitud inclusión en el programa de reubicación o reasentamiento de familias ubicadas en zonas de alto riesgo.

Colombia (2010). Sentencia T-458 de 2010.Acción de tutela instaurada por Mercedes Herrera Novoa, Zoila de Jesús Ortega Mojica, Elizabeth Esther Morales Herrera, Mercedes María Morales Herrera, Tania Luz Morales Herrera, Rocío del Pilar Morales Soto, Marena Morales Ortega, Andrés José Ternera Ortega, y Antonio Rafael Ortega de la Rosa contra la Agencia Presidencial para la Acción Social y la Cooperación Internacional - Acción Social. Corte Constitucional de Colombia. MP. Luis Ernesto Vargas Silva.

Colombia (2011). Sentencia C-132 de 2011. Demanda de inconstitucionalidad contra el Acto Legislativo 03 de 2011. Corte Constitucional. MP. Humberto Antonio Sierra Porto.

Colombia (2012). Sentencia C-288 de 2012.Demanda de inconstitucionalidad contra el Acto Legislativo 3 de 2011 "por el cual se establece el principio de sostenibilidad fiscal” y contra la Ley 1473 de 2011 “por medio de la cual se establece una regla fiscal y se dictan otras disposiciones.Corte Constitucional. M.P. Luis Ernesto Vargas Silva 
Colombia (2012). Sentencia C-332 de 2012.Demanda de inconstitucionalidad contra el Acto Legislativo 03 de 2011.Corte Constitucional. M.P. Humberto Antonio Sierra Porto

Colombia (2012). Sentencia C-1052 de 2012.Demanda de inconstitucionalidad contra el Acto Legislativo 3 del 1 de julio de 2011 (parcial)“Por el cual se establece el principio de sostenibilidad fiscal. Corte Constitucional. M.P. Jorge Ignacio Pretelt Chaljub

Colombia (2012). Sentencia C-584 de 2014.Demanda de inconstitucionalidad contra la Ley 1695 de 2013 "por medio de la cual se desarrolla el artículo 334 de la Constitución Política y su dictan otras disposiciones. Corte Constitucional. M.P. Luis Ernesto Vargas Silva

Colombia (2013). Consejo De Estado. Sala Plena De Lo Contencioso Administrativo. Demanda. C.P. Enrique Gil Botero

Consejo de Estado (2013). Solicitud de apertura del incidente de impacto fiscal. Consejero ponente: Enrique Gil Botero. Solicitante: Procurador General de la Nación. Bogotá D.C., veintiocho (28) de mayo de dos mil trece (2013)

Corte Constitucional de Colombia-Jurisprudencia 


\section{DOCTRINA}

Adamovsky, E. (2000) Pensar un nuevo internacionalismo. En Revista Reunión Nro. 8, pp. 17. Buenos aires.

Aguiló, J., Atienza, M., \& Ruiz, J.(2007). Fragmentos para una teoría de la Constitución. Madrid. Editorial Iustel.

Alberoni, F. (1984). Movimiento e instituciónMadrid: Ed. Nacional.

Amartya, Sen. (2010) La idea de la Justicia” Taurus Pensamiento, Colombia, 2010.

Alzate Ocampo, Laura María. ¿La Ley 1695 de 2013 es contraria a la Constitucion Politica por vulnerar el principio de cosa juzgada? Universidad de Manizales, Facultad de Ciencias Jurídicas, Manizales.

Barbosa, O. (2008) Globalización y desmedro de la soberanía de los estados periféricos. Bogotá. Escuela Superior de Administración Pública.

Briceño C. (2007). El problema de la soberanía: su historia ante el siglo XXI. Caracas: Editorial Equinoccio. Universidad Simón Bolívar.

Bobbio, N. (1985). Stato, gobernó, societá. Einaudi, Turin. 
Bobbio, N. (2002). Teoría General del Derecho, Debate, Madrid.

Böckenförde, E.(2000). Estudios sobre Estado de Derecho y democracia. Ed. Trotta, Madrid.

Capella, J. (2005) La globalización: ante una encrucijada político-jurídica, en Law and justice in a global society, Anales de la Cátedra Francisco Suárez, Granada.

Carvajal, J. (2002) La justicia, el derecho y el conflicto social en Colombia. El otro derecho, numero 28 julio de 2002. Bogotá. Colombia.

Carrillo, F. (2000) "Los retos de la reforma judicial en América Latina" en reforma judicial en América Latina. Una tarea inconclusa, Bogotá, Corporación Excelencia en la Justicia.

Castells, M. (1997). La era de la Información vol. II El poder de la identidad. México: Ed. Siglo XXI.

Castro,J. (2007). Constitución Política de Colombia. Bogotá: Universidad del Rosario.

Defensoría del Pueblo. (2001). Estado de derecho. Imprenta Nacional. Bogotá, Colombia.

Espinosa, J\& González, H.(2004). Prospectiva territorial aplicada en los departamentos de Santander y Casanare. Universidad Externado de Colombia. 
Estrada, S. (2014). El neo constitucionalismo principialista en laasamblea nacional constituyente de 1991. En: Revista Prolegómenos - Derechos y Valores - pp. 27 - 42.

Díaz, L. (2001). Constitucionalismo Social-Hacia un nuevo Estado Social, Democrático de Derecho. Instituto María Cano.

Dworkin, R (1986). Law'Empire. Estados Unidos.Editorial Harvard University Press

Ferrajoli, L.(2005). La crisis de la democracia en la era de la globalización, en Law and justice in a global society, Anales de la Cátedra Francisco Suárez, Granada.

Ferrajoli, L.(2008). Derechos fundamentales, universalismo y multiculturalismo, en Claves de Razón Práctica, no 184, julio/agosto.

Ferrarese, M.(2000). Le istituzioni della globalizzazione, Il Mulino, Bolonia.

Ferrarese M.(2006).Diritto sconfinato. Inventiva giuridica e spazi nel mondo globale, Ed. Laterza, Bari-Roma

Garay, L. (2000). Ciudadanía lo público democracia. Bogotá.Editorial Litocincoa.

Garay, L.(2014). Narcotráfico, corrupción y Estados. Penguin Random House Grupo Editorial México 
George, S. (2000). Seattle, antes, durante y después. En Diario Le Monde diplomatique Nro. 7 , año 1, pp. 4. Enero. Buenos Aires.

Gómez, D. \& Londoño, B.(2010). Diez años de investigación jurídica y socio jurídico en Colombia: balances desde la Red Socio jurídica, tomo II. Bogotá: Universidad de La Sabana

Gómez, G., Mosquera, J.,\& Ochoa, R.(2012). Incidencias negativas del principio de sostenibilidad fiscal en los fallos por responsabilidad patrimonial del estado y los de tutela.Especialización en derecho público financiero. Universidad Libre.

Guastini, R. (2003). La constitucionalización del ordenamiento jurídico: el caso italiano, en Miguel Carbonell (edición de), Neo constitucionalismo(s), Trotta, Madrid

Guerrero Vinueza, Álvaro. (2012). Sostenibilidad fiscal y principios en el Estado Social de Derecho. En: Revista Criterio Jurídico. Santiago de Cali. V. 12, No. 1. Aprobado: 6 de junio de 2012.

Hirsch, J. (1997). ¿Qué es la globalización? En Revista Realidad Económica Nro. 147, pp. 7-17. Buenos aires.

Jiménez, A. (2008).Democracia y Neoliberalismo. Bogotá. Editorial la Carreta Política, 
Laporta, F. (2005) Globalización e imperio de la ley. Un texto provisional para el debate con algunas dudas y perplejidades de un viejo westfaliano, en Law and justice in a global society, Anales de la Cátedra Francisco Suárez, Granada.

Lozano. I.E (2010) Una nota sobre la sostenibilidad fiscal y el nexo entre los ingresos y gastos del Gobierno colombiano. (Versión Electrónica) México B Centro de Estudios Monetarios Latinoamericanos: Monetaria. 33(2). pp 207-238.

Lasalle, F. (2010). ¿Qué es una Constitución?Bogotá: Editorial Temis.

López Caballero, Juan Manuel, Colombia y el modelo de desarrollo del rebusque, Revista Dinero, No 494, Mayo 27 de 2016 p 94.

Landwerlin, Gerardo Meil, El Estado Social de Derecho-Forsthoff y Abbendroth, dos interpretaciones teóricas para dos posiciones políticas, Revista de Estudios políticos ISSN 0048-7694, No 42, 1984, págs. 211-226.

Maternales, M. (1998) El fracaso político del capitalismo. En Revista Realidad Económica Nro. 158, p. 44-65. Buenos aires.

Molina, J. (2008).Democracia en Colombia y Poder Público. Es Público o Privado el Estado en Colombia. Bogotá. Escuela Superior de Administración Pública. 
Monroy, A. (2007). El estado social de derecho en la protección del derecho a la vida y la salud de la mujer embarazada. Maestría en estudios políticos. Pontificia Universidad Javeriana.

Naranjo,V. (1984). Elementos de teoría constitucional e instituciones políticas. Indagraf Editores, 1984

Núñez, A. (2005). Manifiesto por una justicia constitucional responsable. Legis, 2005.

Quintero, N.El carácter normativo del estado social de derecho en Colombia. En Revista Precedente 2002.

Ramirez, R. (2000). Pinchar el Globo a la Globalización. En Revista Reunión Nro. 8, pp. 16. Buenos Aires.

Rauber, I. (2003). América Latina. Movimientos Sociales. Representación Política. Bogotá: Ediciones Desde Abajo.

Rivero, R. \& Berdugo,I. (2003). El Estado de derecho latinoamericano. Integración económica y seguridad jurídica en Iberoamérica. Universidad de Salamanca. 
Salazar, P. (2006). La democracia constitucional una radiografía teórica. Ediciones Fondo de Cultura Económica Instituto de Investigaciones Jurídicas- UNAM.P 82, México Distrito Federal.

Silva, J. (enero-junio 2012). Evolución y origen del concepto de "estado social” incorporado en la Constitución Política Colombiana de 1991. EnRevista Ratio Juris Vol. 7 Nº 14 pp. 141158 @ Unaula

Steger, M. (2003). Globalization: A Very Short Introduction, Oxford University Press.

Tello, C.B. \&Ramírez, A.R. (1999). Alternativas y cambios en las estrategias sindicales argentinas frente al fenómeno global. Ponencia presentada en la III Reunión de Antropología del Mercosur (RAM), Noviembre.

Torres, Juan (1998). "Sobre democracia y economía. Algunas reflexiones contra la corriente". En Revista internacional de Filosofía Política. No 12 diciembre. Madrid.

Vidal, J. (1996). Derecho constitucional general e instituciones políticas colombianas. Bogotá: Universidad Externado de Colombia y Universidad Nacional de Colombia.

Vila, I. (2007). Fundamentos del derecho constitucional contemporáneo. Bogotá: Legis. 
Zibechi, R. (2008). América Latina: Periferias Urbanas, Territorios en resistencia. Bogotá:Ediciones desde abajo.

\section{PAGINA WEB}

Téllez Iregui, Alberto (2010). La dictadura fiscal el estado contra la sociedad y la Constitución. Recuperado de http://es.slideshare.net/PoloDemocratico/la-dictadura-fiscal3-albertotellez.

CICR (1949). II. Convenio de Ginebra para aliviar la suerte que corren los heridos, los enfermos y los náufragos de las fuerzas armadas en el mar, 1949. Recuperado de: http://www.icrc.org/spa/resources/documents/treaty/treaty-gc-2-5tdkwc.htm

CICR (1977). Protocolo II adicional a los Convenios de Ginebra de 1949 relativo a la protección de las víctimas de los conflictos armados sin carácter internacional, 1977. Recuperado de: http://www.icrc.org/spa/resources/documents/misc/protocolo-ii.htm
Montagut,
E.
(2010).Conservadurismo.
Recuperado
de

http://historiaideologias.blogspot.com/2010/01/conservadurismo.html

Pérez Vanegas, L. (s/f). La sostenibilidad fiscal en el marco del estado social de derecho en Colombia. En: Revista Virtual Legem. Universidad del Atlántico. Facultad de Ciencias 
Jurídicas.

Recuperado

dehttp://investigaciones.uniatlantico.edu.co/revistas/index.php/legin/article/view/906/592

Arango, R. (s/f). Sustitución del Estado Social de Derecho por un Estado Fiscal. Revista de la Universidad Externado de Colombia Facultad de Finanzas, Facultad de Finanzas, $\begin{array}{lllll}\text { Gobierno } & \text { y } & \text { Relaciones } & \text { Internacionales. }\end{array}$ http://portal.uexternado.edu.co/pdf/5_revistaZero/ZERO27/14.\%20sustitucion.pdf

González, A. (2007). El estado social de derecho en la protección delderecho a la vida y la salud de la mujer embarazada. Tesis de grado Maestría en Estudios Políticos. Bogotá. $\begin{array}{lll}\text { Universidad Javeriana. } & \text { Recuperado }\end{array}$ www.javeriana.edu.co/biblos/tesis/politica/tesis70.pdf

Stiglitz, J. (6 Septiembre, 2014). Democracia en el siglo XXI. En: El Espectador. Recuperado de http://www.elespectador.com/opinion/democracia-el-siglo-xxi-columna-515130 